\title{
ZUR ENTWICKLUNG DER PARTIZIPIAL- UND GERUNDIALKONSTRUKTIONEN AUF -Č UND -ک̌I IN DER SLOWENISCHEN SCHRIFTSPRACHE DES 19. JAHRHUNDERTS ${ }^{1}$
}

\section{$\underline{\text { OEinleitung }}$}

Die Partizipial- und Gerundialkonstruktionen auf - $\check{c}$ und -ši in der slowenischen Schriftsprache des 19. Jahrhunderts wurden in der gesprochenen Sprache kaum verwendet, und waren auch in der Entwicklungsgeschichte der Literatursprache zentralslowenischen Typs seit dem 16. Jahrhundert schlecht vertreten. ${ }^{2}$ Das Interesse für diese alten syntaktischen Kategorien verstärkte sich jedoch unerwartet im 19. Jahrhundert: Das ist die Zeit der ersten Übermittlungen der Bemühungen für eine eigene Schriftsprache in Prekmurje, wo die Partizipial- und Gerundialkonstruktionen auf -č und -ši bereits seit den Erstausgaben stark vertreten waren. ${ }^{3}$ Im 19. Jahrhundert wurden

1 Der vorliegende Artikel ist die gerürte Fassung der Dissertation (Ljubljana, 1994), angenommen (19.5.1995) an der Philosophischen Fakultät der Universität Ljubljana (Mentorin Prof. Dr. M. Orožen; Gutachter Prof. Dr. J. Toporišič, Prof. Dr. Z. Zorko).

2 M. Orožen stellt fest, daß die zentralslowenische Schriftsprachenvariante vom 16. bis 19. Jahrhundert von einer Auflösung der Partizipial- und Gerundialsysteme geprägt ist; das gilt vor allem für die Formen auf -ši, die äußerst selten und unproduktiv geworden sind (Participske konstrukcije, 123-124).

3 Die erstgedruckte Buchausgabe in Prekmurje ist Temlins Übersetzung des Kleinen Katechismus von Luther (Mali Katechismus, Halla 1715); zehn Jahre später wurde anonym Abecedarium szlowenszko herausgegeben; 1847 erschien Réd zvelicsánsztva, bearbeitet und übersetzt von M. Sever, in den 50er Jahren erschienen die Buchausgaben von Š. Küzmič Vöre krsztsánszke krátki návuk (Halla, 1754). Es ist anzunehmen, daß einige Werke von Š. Küzmič bereits vor 1754 gedruckt wurden - vgl. dazu unbewahrte Druckausgaben aus den Jahren 1752 und 1753, registriert in Bibliografija prekmurskih tiskov od 1715 do 1919, Ljubljana 1978, verfaßt von I. Škafar und bearbeitet von V. Novak. Š. Küzmičs Nouvi Zákon (v Halli Saxonskoj, 1771) galt als Vorbild für spätere protestantische und katholische Verfasser und Übersetzer in Prekmurje -"die alte slowenische Sprache" bewährte sich in der ersten slowenischen Übersetzung des Neuen Testaments aus dem Griechischen. Da die prekmurjische Variante der slowenischen Schriftsprache in den Grammatiken jener Zeit nicht beschrieben war, galt der Sprachgebrauch im Neuen Testament als Norm und Vorschrift. Sein morphologisch-syntaktischer Einfluß auf den Sprachgebrauch in Prekmurje ist etwa dem Einfluß der Bibelübersetzung Dalmatins (Biblija, 1584) auf die Sprachverwendung in der 
sie im gesamten zentralslowenischen Raum bekannt; ${ }^{4}$ während der dritten bzw. fünften Entwicklungsphase wurden sie sogar so häufig gebraucht wie etwa in der ostslowenischen Schriftsprache des 18. und der ersten Hälfte des 19. Jahrhunderts. Die Frage, warum die Partizipial- und Gerundialkonstruktionen auf - $\breve{c}$ und - ̌si in der Schriftsprache von Prekmurje sich erhalten hatten, erweckte das Forschungsinteresse für den pannonischen Sprachraum, da hier erhebliche dialektale Unterschiede im Vergleich zur Sprachtradition im slowenischen Alpenraum festzustellen sind. Es bestehen lexikalische sowie phonetisch-morphologisch-syntaktische Besonderheiten, die u.a. auch in verschiedenen Übersetzungsvorlagen begründet sind. Bei diesen handelt es sich entweder um die griechisch-altkirschenslawische Tradition des pannonischen oder um die lateinisch-deutsche Tradition des Alpenraumes. Hinweise auf solche Einflüsse gibt es bereits in den 70er Jahren bei M. Orožen, ${ }^{5}$ obgleich die slowenische Sprachwissenschaft zu dieser Zeit noch fest davon überzeugt war, daß die Partizipialformen auf -č und -ši in der Schriftsprache von Prekmurje als Lehnübersetzungen aus dem Griechischen zu interpretieren sind, ${ }^{6}$ denn als Fremdelemente sollten sie sich in der vom benachbarten Kajkavischen abhängigen Schriftsprache von Prekmurje erhalten haben. ${ }^{7}$ Die vergleichen-

zentralslowenischen Literatursprachenvariante im 17. und 18. Jahrhundert gleichzusetzen.

M. Jesenšek verweist in seiner Magisterarbeit (Skladenjski sistem /.../, Ljubljana 1989) auf die intensive Ausbreitung der Partizipial- und Gerundialkonstruktionen auf -č und - $s \mathrm{i}$ in der zentralslowenischen Schriftsprache (M. Ravnikar, Zgodbe svetega pisma za mlade ljudi, 1815-1816), indem er zwei Übersetzungen des Neuen Testaments vergleicht (Š. Küzmič, 1771; J. Japelj, 1784).

5 Sie weist darauf hin, daß "auf dem gesamten Gebiet der pannonischen dialektalen Basis in sämtlichen Varianten der Schriftsprache eine mehr oder weniger identische syntaktische Struktur zu beobachten ist, die aber im Vergleich zum zentralslowenischen Sprachgebrauch typologische Unterschiede aufweist." (O vzhodnoslovenskem knjižnem jeziku. In: Zbornik Štefana Küzmiča, Murska Sobota 1974, 120). Sie vertritt die Auffassung, daß zwischen der Schriftsprache von Prekmurje und dem pannonischen Altkirchenslawischen (von glagolitischer Sprachtradition getragen) feste Zusammenhänge bestehen. In ihren zwanzigjährigen systematischen Sprachforschungen hat sich diese Auffassung immer wieder als richtig erwiesen. Vgl. ebenso die Abhandlungen über die pannonische Theorie von der Entstehung des Altkirchenslawischen, der Freisinger Denkmäler und der ostslowenischen Schriftsprache (im folgenden seien nur die wichtigsten genannt: Molitveni obrazci /.../, Slavistična revija 1986, 37-57; Prekmurski knjižni jezik, Seminar slovenskega jezika, literature in kulture 1989, 37-60, Brižinski spomeniki in njihovo razmerje do stare cerkvene slovanščine, Obdobja 10, 1989, 87-101).

6 "In Štefan Küzmičs Nouvi Zakon (1771) zeigen sich - mit der traditionellen Schriftsprache verglichen - wesentliche Unterschiede im Gebrauch des Part. Prät. act. I. Da Küzmič nach der griechischen Vorlage übersetzte, wurde dieses Partizip oft als slowenische Entsprechung des griechischen Part. Aorist verwendet" (F. Tomšič, Poglavje iz slovenske historične sintakse, Slavistična revija 1958, 59). A. Vratuša dagegen räumt dem Übersetzer des Neuen Testaments mehr Freiheit ein, "denn obwohl die Besonderheiten der griechischen Syntax stark nachahmend, übersetzte er hie und da die griechischen Partizipialkonstruktionen mit einem Satzgefüge." (Jezik "Nouvoga zákona" in "Szvéti evangyeliomov". In: Zbornik Štefana Küzmiča, Murska Sobota 1974, 68).

Die Auffassung über die Abhängigkeit vom Kajkavischen vertritt auch V. Novak, obwohl er die 
den Betrachtungen von Partizipialkonstruktionen auf -č und -ši in der prekmurjischen Schriftsprache des 18. Jahrhunderts ( ̌̌. Küzmič, Nouvi zakon 1771) und der entsprechenden syntaktischen Lösungen in den altkirchenslawischen Evangelien bestätigten die Thesen von M. Orožen, denn es wurden in beiden Sprachen dieselben Gesetzmäßigkeiten im Gebrauch der -č- und -ši-Formen evident, obwohl Š. Küzmič bei seiner Übersetzungsarbeit die altkirchenslawischen Vorlagen nicht verwendet hatte. ${ }^{8}$ Beweise dafür, daß die altkirchenslawischen Partizipialkonstruktionen keine Lehnübersetzungen aus dem Griechischen sind, sondern daß es sich hier um typische syntaktische Mittel der slawischen Sprachen handelt, gibt es bereits bei R. Večerka. ${ }^{9}$ Die Ergebnisse seiner Untersuchungen beachtet auch M. Jesenšek, indem er versucht, die Kontinuität im Gebrauch von -č- und -ši-Formen im pannonischen Sprachraum seit dem Altkirchenslawischen bis zur prekmurjischen Schriftsprache in der zweiten Hälfte des 18. Jahrhunderts nachzuweisen. Die Gebrauchshäufigkeit der verwendeten Partizipialformen in der ostslowenischen Variante der slowenischen Schriftsprache ist vergleichbar mit jener in den schriftlichen Denkmälern des Altkirchenslawischen (so Večerka), jedoch sind sie im pannonischen Raum den

These von den Zusammenhängen mit der glagolitischen Tradition sowie auch die Annahmen über die Berührungspunkte der prekmurjischen Schriftsprache mit dem Altkirchenslawischen nicht akzeptiert; jedoch haben sich diese im Rahmen der Untersuchungen von Partizipialkonstruktionen auf $-\breve{c}$ und - ̌s bei $\breve{S}$. und M. Küzmič als richtig erwiesen (Vgl. M. Jesenšek, Skladenjski sistem /.../, Magisterarbeit, Ljubljana 1989). Es scheint nicht berechtigt zu sein, die Formen auf -č und -ši zu den "wichtigsten kajkavischen Elementen im Sprachgebrauch der Verfasser von Prekmurje" zu zählen (V. Novak, Kajkavske prvine v prekmurski knjigi 18. stoletja. In: Slavistična revija, 1972, 95). Auch die Behauptung, die Formen auf -č bei Š. Küzmič "seien nach dem kajkavischen Vorbild (z. B. Krajačevič) verwendet", konnte bis jetzt noch nicht bewiesen werden. V. Novak stellt zwar fest, daß "die Partizipien auf -č oft vorkommen" (98), woher stammen jedoch die Formen auf -ši, für die sich M. Ravnikar so sehr begeisterte? V. Novak gesteht morphologische Einflüsse des Kajkavischen ein, berücksichtigt die differenten syntaktischen Strukturen der betreffenden Sprachen aber nicht, obgleich sie aufgrund der funktionalen Vielfalt der Formen auf -č und -ši klar erkennbar sind. Dasselbe bestätigt die vergleichende Untersuchung der Partizipialkonstruktionen bei $\breve{S}$. und $M$. Küzmič und ihrer syntaktischen Entsprechungen bei N. S. Krajačevič (Sveti evangeliomi, 1651) (M. Jesenšek, Magisterarbeit; vgl. dazu seinen Beitrag in Znanstvena revija, 1989, Nr. 2, 215-234). Es hat sich herausgestellt, daß diese Partizipien zu den ursprünglichen slowenischen und slawischen Formen zu zählen sind. V. Novak vertritt eine andere Auffassung: "Fremd sind auch einige Satzkonstruktionen, vor allem Partizipialkonstruktionen anstelle von Nebensätzen, wobei ihm (J. Košič) die beiden Küzmičs als Vorbild dienten /.../, besonders oft gebraucht er die Partizipien auf -vši." (V. Novak, Jožef Košič prekmurski pisatelj, Razprave SAZU, Ljubljana 1958, 273). Novak konnte sich außerdem nicht entscheiden, ob die Verfasser aus Premurje im 18. und in der ersten Hälfte des 19. Jahrhunderts in einem Dialekt schreiben ("Geschrieben im Dialekt von Prekmurje /...", Izbor prekmurskega slovstva, Ljubljana 1976, 12) oder ob sie eine Schriftsprache verwenden (" Wir sind lediglich in der Lage, einen allgemeinen Überblick über die Hauptmerkmale der prekmurjischen Schriftsprache - diesen Terminus akzeptierte zur Zeit auch die slowenische Sprachwissenschaft - zu geben." Izbor /.../, 13).

8 M. Jesenšek: Skladenjski sistem /.../, Magisterarbeit, Ljubljana 1989.

9 R. Večerka: Syntax aktivních participií v staroslověnštině, Prag 1961. 
morphologisch-syntaktischen Eigenschaften des Prekmurjischen funktional angepaßt (so ist z. B. der altkirchenslawische absolute Dativ durch den prekmurjischen absoluten Nominativ ersetzt worden). Die Wiederbelebung von alten -č- und -ši-Formen in der zentralslowenischen Schriftsprache der ersten Hälfte des 19. Jahrhunderts und ihr Eindringen ins morphologisch-syntaktische System der gesamtslowenischen Schriftprache in der zweiten Hälfte des 19. Jahrhunderts sind die Folge einer Konfrontierung differenter syntaktischer Systeme von zwei Typen der slowenischen Schriftsprache sowie die Folge der Normierung der gesamtslowenischen Schriftsprache in der Mitte des 19. Jahrhunderts. Entwicklungshistorisch wurden dabei die Ergebnisse der phonetischen, morphologischen und syntaktischen Gesetzmäßigkeiten der slowenischen Schriftsprache sowie das archaische altkirchenslawische System der Partizipien und Gerundien als auch die nachahmende Syntax der ostlowenischen Schriftsprache um die Wende des 19. Jahrhunderts berücksichtigt. Bei M. Ravnikar handelte es sich zwar noch um einen "eher mißlungenen Applikationsversuch", jedoch wußte F. Metelko in seiner Grammatik (1825) sämtliche morphologische und funktionale Ungeschicklichkeiten seiner Zeitgenossen zu verbessern. ${ }^{10}$ Demzufolge verbreiteten sich die betreffenden Partizipialformen noch vor der Mitte des Jahrhunderts im gesamten slowenischen Sprachraum. Ihre Gebrauchshäufigkeit änderte sich im 19. Jahrhundert, und war im Vergleich zum Sprachgebrauch im Zentraltyp der slowenischen Schriftsprache von P. Trubar bis J. Japelj bzw. bis hin zur Verwendung in den literarischen Texten im Zeitalter der Aufklärung und Romantik sehr hoch, obwohl - mit der Ausnahme von F. Levstik - nie so sehr wie etwa in der prekmurjischen Schriftsprache des 18. und der ersten Hälfte des 19. Jahrhunderts. Der Gebrauch von -č- und -ši-Formen war entscheidend beeinflußt von der Zeitepoche (sechs Zeitabschnitte in der Entwicklung der betreffenden Formen in der Sprache des 19. Jahrhunderts), von der jeweiligen Literaturgattung (religiöse und profane Literatur) sowie vom Funktionsstil (schöne Literatur vs. Sachliteratur, d.h. Fach- und Pressetexte bzw. Texte der alltäglichen Kommunikation).

10 Der Versuch galt als "mißlungen" (M. Orožen, Participske konstrukcije, 132), denn M. Ravnikar war sich der morphologischen Eigenschaften sowie auch der syntaktischen Möglichkeiten von -č- und -ši-Formen nicht voll bewußt. In bezug auf die Derivation übersah er den Aspekt, ebenso waren ihm die Regeln für den Gebrauch der Partizipien zum Ausdruck der Zeitverhältnisse nicht bekannt. Die Partizipialkonstruktionen begeisterten ihn lediglich als wirkungsvolle syntaktische kondensierende Strukturen, während er keine Gleich- und/oder Vorzeitigkeit mit ihnen ausdrücken konnte. Trotzdem ist Ravnikars Auffassung von den Partizipialkonstruktionen als bedeutsam zu bewerten, denn er war der Erste, der zwei unterschiedliche morphologisch-syntaktische Systeme der slowenischen Schriftsprache gegenüberstellte; weiterhin förderte er den Gebrauch von archaischen ostslowenischen Elementen im zentralslowenischen Sprachraum und wirkte dadurch bei der Verflechtung zweier Schriftnormen der slowenischen Schriftsprache am Anfang des 19. Jahrhunderts wesentlich mit. Indirekt schuf er Voraussetzungen für ihre weitere gegenseitige Beeinflussung und für die Normierung einer einheitlichen slowenischen Schriftsprache in der Mitte des 19. Jahrhunderts. 
Das untersuchte Sprachmaterial wurde in der Regel Texten aus dem 19. Jahrhundert entnommen, allerdings reichen die prekmurjischen Belege wegen der ostslowenischen Variante der Schriftsprache bis in das Jahr 1771 zurück, wobei auch die -č- und -ši-Formen in Š. Küzmičs Nouvi zakon berücksichtigt sind. Das Sprachmaterial aus dem zentralslowenischen Sprachraum enstammt den bis 1900 erschienenen Texten (die fachsprachlichen Texte wurden bis 1906 einbezogen - K. Štrekelj, Časopis za zgodovino in narodopisje); in Prekmurje wurden noch die Neuauflagen von Š. und M. Küzmičs Übersetzungen (Š. Küzmič, Nouvi zakon, 1928) ausgewertet, in denen keine Veränderungen in der Morphologie und Syntax der Partizipialkonstruktionen festzustellen sind; im 20. Jahrhundert hingegen verschwinden diese aus dem Sprachgebrauch in der prekmurjischen Presse ( $z$. B. Marijin list, Novine); schließlich folgen noch Orientierungsbelege aus der gegenwärtigen Fach- und Pressesprache $(1992,1993)$. Die Partizipialkonstruktionen auf $-\check{c}$ und $-s ̌ i$ wurden jeweils samt Kontext exzerpiert und sind im Anhang der Dissertation gesammelt. Das untersuchte Sprachmaterial umfaßt 5530 Belege; davon sind 1898 Partizipien in nominaler Funktion (im folgenden Partizipien; 1814 auf $-\check{c}, 84$ auf $-\check{s}$ ) ) und 3632 Partizipien in verbaler Funktion (im folgenden Gerundien; 1617 auf -č, 1432 auf -ši/67 auf $-\varnothing /$-v/ und 583 auf -/aj/e).

Tabelle 1: Gesamtanzahl der exzerpierten Partizipial- und Gerundialkonstruktionen auf $-\check{c}$, -ši und -/aj/e

\begin{tabular}{|c|c|r|r|r|}
\hline \multicolumn{2}{|c|}{} & Partizip & Gerundium & Gesamt \\
\hline F & $-\check{c}$ & 1814 & 1617 & 3431 \\
\cline { 2 - 5 } 0 & $-\check{s} i$ & 84 & 1365 & 1449 \\
\cline { 2 - 5 } r & $-\varnothing$ & & 67 & 67 \\
\cline { 2 - 5 } m & $-/$ aj/e & & 583 & 583 \\
\hline \multicolumn{2}{c}{ Gesamt } & 1898 & 3632 & 5530 \\
\hline
\end{tabular}

Das Sprachmaterial wurde aus 266 Buchausgaben und 36 Zeitungstiteln exzerpiert; die Texte unterscheiden sich umfangsmäßig, allerdings wurden nicht sämtliche Autoren des 19. Jahrhunderts zur Analyse herangezogen. Trotzdem scheint die Auswahl der Belege typisch und repräsentativ genug zu sein, um nachzuweisen, daß die Partizipial- und Gerundialkonstruktionen auf -č und -ši in der Schriftsprache des 19. Jahrhunderts aufs neue entdeckt und im Vergleich zu den in der ostslowenischen Schriftsprache nicht vorhandenen Formen auf -aje auch häufig verwendet wurden. Aus der Analyse des Sprachmaterials geht hervor, daß die Gerundien mit 65,68\% überwogen; die Formen auf -č und -ši stehen dabei proportional zueinander $(29,24 \%: 24,68 \%)$. Zum Ausdruck der Gleichzeitigkeit dienten zusätzlich noch die Formen auf -/aj/e (10,54\%), während Vorzeitigkeit eher ausnahmsweise mit den Formen auf $-\varnothing$ bzw. -v ausgedrückt wurde $(1,22 \%)$. Unter den Partizipien $(34,32 \%)$ dominieren die Formen auf -č $(32,8 \%)$, die -ši-Formen hingegen sind mit 1,52\% nur schwach vertreten. Das Ergebnis ist überraschend, denn gerade die letzteren haben sich bis heute bewahrt - im Unterschied zu 
den Gerundien, die heute selten geworden sind. Die in der Tabelle zusammengestellten Angaben über die Anzahl der exzerpierten Formen auf -č und -ši sollen vor allem ein informativer Ausgangspunkt für die Festlegung ihrer Gebrauchshäufigkeit sein. Ein genaueres Bild darüber bieten erst die Angaben über ihren Durchschnittsgebrauch an, der sich aus umfangsmäßig gleichen Textsamples verschiedener Autoren und Übersetzer ${ }^{11}$ ergibt und einen Vergleich in bezug auf die literarischen Gattungen in dem ost- und zentralslowenischen Sprachraum sowie auf den Funktionsstil und die chronologische Einordnung der untersuchten Texte zuläßt.

\section{Literarische Gattungen im ost- und zentralslowenischen Sprachraum}

Es ist im zentralslowenischen Sprachraum vom 16. bis 19. Jahrhundert ein merklicher Rückgang im Gebrauch der Partizipial- und Gerundialkonstruktionen auf -č und -ši festzustellen. ${ }^{12}$ Unter dem Einfluß der ostslowenischen Schriftsprache (die prekmurjische Variante der Schriftsprache, entscheidend ist Š. Küzmičs Übersetzung von Nouvi zakon), kam es im 19. Jahrhundert zur Wiederbelebung dieser Formen und zur erneuten Zunahme ihrer morphologischen Produktivität. Interessanterweise sind die Formen auf -č und -ši in der zentralslowenischen Schriftsprache auf die religiöse Literatur zurückzuführen (das gilt hauptsächlich für protestantische Texte, obwohl die betreffenden Formen in Prekmurje auch in der katholischen und sogar profanen Literatur (Initiator J. Košic ${ }^{13}$ ) verbreitet waren. Es ist jedoch evident, daß sie im zentralslowenischen

11 Zuverlässige Resultate setzen eine umfangreiche Analyse des Sprachmaterials voraus. Beim Vergleich der religiösen und profanen Literatur wird der Durchschnittsgebrauch der -č- und -ši-Formen auf einer Seite des Textes (30 Zeilen) bei 100 exzerpierten Seiten festgelegt; beim funktionalstilistischen bzw. chronologischen Vergleich der untersuchten Texte konnte eine solche Norm nicht mehr konsequent berücksichtigt werden, da das Sprachmaterial zu umfangreich war. Auf kürzere Texte (weniger als 100 Seiten) wird in der Tabelle zusätzlich hingewiesen. Die auf diese Weise erhaltenen Resultate sind vergleichbar mit den entsprechenden Untersuchungen für das Tschechische. E. Dvořak stellt fest, daß "jsou ve spis. češtině /Partizipialkonstruktionen/ prostředkem ustupujícím." (Přechodníkové konstrukce v nové češtině, Prag 1983, 85), J. V. Bečka dagegen meint, daß solche Formen im Tschechischen nicht verlorengegangen sind, obwohl er ihren Rückgang in der gegenwärtigen tschechischen Literatur anerkennt ("...ale přes to je prechodnikJ.../ útvar ve psaném jazyce stále živý." Vgl. seine Abhandlung $O$ přechodníku v současné beletrii, in: Naše ře č 1941/25, 150). In der slowenischen Schriftsprache des 20. Jahrhunderts wirken sie zwar archaisch und sind stark im Rückgang begriffen, nehmen jedoch ihren Platz in der Grammatik ein (J. Toporišič, Slovenska slovnica, Maribor 1976, 339-341; ebenso in der 2. (1984) und 3. (1991) Ausgabe).

12 Vgi. ihren seltenen Gebrauch bei den Protestanten und einen Rückgang der -ši-Formen bei katholischen Verfassern im 17. und 18. Jahrhundert. Hinweise darauf gibt es in der bereits zitierten Abhandlung von $M$. Orožen mit dem Titel Participske konstrukcije.

13 Eine Auswahl von Košičs Schriften ist unter dem Titel Življenje Slovencev med Muro in Rabo erhältlich (Budapest 1992, zusammengestellt von V. Novak und S. Lukič, redigiert von M. Bajzek). 
Sprachraum eher in den profanen als in den katholischen Schriften zu finden sind. In Dalmatins Schriftsprache sowie in ihrer grammatischen Umformung mit Japeljs Bibelübersetzung am Ende des 18. Jahrhunderts wurden hauptsächlich Gesetzmäßigkeiten der oberkrainerischen Dialektbasis berücksichtigt, ${ }^{14}$ denn Japelj und seinen Mitarbeitern waren weder die prekmurjische Übersetzung von Nouvi zakon (1771) noch die katholischen Evangelienausgaben (M. Küzmič, 1780) bekannt. In gewisser Weise wurde das Slowenische dadurch von seinem ursprünglichen phonetischmorphologisch-syntaktischen System entfernt, das im pannonischen Raum noch erhalten war. Die moderne Vokalreduktion und starke dialektale Spaltung des Zentralslowenischen im Alpenraum waren ein hinreichender Grund für die Aufhebung archaischer Elemente auf diesem Sprachgebiet. Dasselbe gilt auch für die syntaktische Komprimierung mit Hilfe von Partizipien, denn die Formen auf -ši sind in der zentralslowenischen Schriftsprache bald nach der Entstehung der Freisinger Denkmäler morphologisch unproduktiv geworden. Aufgrund der 200-jährigen schriftsprachlichen Tradition in diesem Raum und deren Wandel am Ende des 18. Jahrhunderts, die hauptsächlich den zentralslowenischen Sprachgebrauch berücksichte, konnten die wiederbelebten archaischen Formen auf -č und -ši keine Verbreitung in der slowenischsprachigen religiösen Literatur des 19. Jahrhunderts finden. In den katholischen Zeitschriften wurden die -ši-Formen sogar redaktionell verdrängt und konnten sich auch in der gesprochenen Sprache nicht durchsetzen, wohl aber in der profanen Literatur, wo sie zu den wichtigsten syntaktischen und stilistischen Sprachmitteln wurden (Kondensation, gehobener Sprachstil).

\subsection{Religiöse Literatur}

Für den Anteil der -č- und -ši-Formen an der religiösen Literatur des 19. Jahrhunderts sind zwei Extreme zu konstatieren: Einerseits wurden diese Formen in der Schriftsprache von Prekmurje äußerst häufig verwendet, andererseits waren sie aber (vor allem Gerundien auf -ši) in den zentralslowenischen Schriften unerwartet schwach vertreten, obwohl gerade diese Texte den oststairischen Verfassern und Übersetzern der religiösen Literatur als Vorbild dienten. ${ }^{15}$

14 M. Orožen: Gramatična in leksikalna preobrazba Dalmatinovega knjižnega jezika ob Japljevem prevodu Biblije. In: Wiener slawistischer Almanach, Sonderband 13, Protestantismus bei den Slowenen, Klagenfurt und Ljubljana 1983, 155.

15 In dieser Hinsicht ist A. Krempl zu erwähnen. Er übersetzte die Evangelien (1843) nach den Regeln der "traditionellen" slowenischen Sprache (d.h. er kannte zwar die Formen auf -č, die gerundialen -ši-Formen verwendete er aber nicht; vgl. M. Jesenšek, Raba deležijskih in deležniških oblik na -oč/-eč v vzhodnoštajerskem knjižnem jeziku, in: Časopis za zgodovino in narodopisje, 1992, 60-72). Sein historischer Text Dogodivšine štajerske zemle (1848) ist hingegen von erkennbaren Merkmalen der ostslowenischen Morphologie und Syntax geprägt. U.a. zeigen sich diese im Gebrauch der pannonischen Partizipialkonstruktionen, obwohl er für einen solchen Stil im zentralslowenischen Raum kein Vorbild finden konnte (vgl. dazu M. Jesenšek, Oblikoslovno- 
Tabelle 2: Durchschnittshäufigkeit der Partizipialkonstruktionen auf -č und -ši in der religiösen Literatur ${ }^{16}$

\begin{tabular}{|c|c|c|c|c|c|c|c|c|c|c|c|c|c|}
\hline & \multicolumn{12}{|c|}{ Religöse Literatur } \\
\hline & & \multicolumn{6}{|c|}{ Ostslowenischer Raum } & \multicolumn{6}{|c|}{ Zentralslowenischer Raum } \\
\hline & & \multicolumn{2}{|c|}{ Partizip } & \multicolumn{2}{|c|}{ Gerundium } & \multicolumn{2}{|c|}{ Gesamt } & \multicolumn{2}{|c|}{ Partizip } & \multicolumn{2}{|c|}{ Gerundium } & \multicolumn{2}{|c|}{ Gesamt } \\
\hline & & $\mathrm{p} / 700$ & $\mathrm{dp} / 1$ & $\mathrm{~g} / 700$ & $\mathrm{dg} / 10$ & $\mathrm{pg} / 700$ & $\mathrm{pg} / 10$ & $\mathrm{p} / 700$ & $\mathrm{dp} / 10$ & $\mathrm{~g} / 700$ & $\mathrm{dg} / 10$ & $\mathrm{pg} / 700$ & $\mathrm{pg} / 10$ \\
\hline \multirow{2}{*}{ Form } & $-\check{c}$ & 531 & 7,6 & 310 & 4,42 & 841 & 12 & 187 & 2,6 & 85 & 1,2 & 272 & 3,9 \\
\hline &.$- \breve{i}$ & 25 & 0,35 & 191 & 2,73 & 216 & 3,1 & 23 & 0,32 & 44 & 0,6 & 67 & 0,9 \\
\hline \multicolumn{2}{|c|}{ Gesamt } & 556 & 7,95 & 501 & 7.15 & 1057 & 15.1 & 210 & 2.92 & 129 & 1,8 & 339 & 4,8 \\
\hline
\end{tabular}

Die Gebrauchsfrequenz der Partizipialkonstruktionen auf -č und -ši in der religiösen Literatur des ostslowenischen Raumes ist im Vergleich mit den zentralslowenischen religiösen Texten 3,11mal höher. In den religiösen prekmurjischen Schriften des 19. Jahrhunserts liegt der Anteil an -č- und -ši-Formen bei 75,71\% (Partizipien 72,58\%, Gerundien 79,52\%). Die Durchschnittshäufigkeit der in der gesamtslowenischen religiösen Literatur verwendeten Partizipialkonstruktionen auf -č und -ši je zehn Textseiten beträgt 9,95 (15,1 im Osten, 4,8 im Zentrum des slowenischen Sprachgebiets), wobei die Partizipien öfter als Gerundien vorkommen $(5,43$ : 4,47); ebenso sind die Formen auf -č zahlreicher als diejenigen auf -ši $(7,95: 2)$.

Aus der Tabelle 2 sind weiter zwei unterschiedliche Entwicklungstendenzen im Gebrauch der -č- und -ši-Formen in der slowenischen religiösen Literatur des 19. Jahrhunderts ersichtlich. Im Osten werden sie extrem häufig verwendet, während sie im zentralslowenischen Raum äußerst selten vorkommen - das gilt besonders für die -šiFormen, die nur 0,9 mal pro zehn Textseiten erscheinen. In Vergleich mit der prekmurjischen religiösen Literatur verringerte sich im zentralslowenischen Raum hauptsächlich die Anzahl der Gerundien auf -ši $(2,73: 0,6)$, während der Gebrauch von Partizipien auf -ši fast gleichgeblieben ist $(0,35: 0,32)$. Die Unterschiede im Gebrauch der Gerundien auf -ši basieren auf zwei, u.a. auch syntaktisch voneinander abweichenden schriftsprachlichen Traditionen. Aufgrund der Ausdrucksstärke beider Varianten des Slowenischen im 19. Jahrhundert können wir einen hohen Kultivierungsgrad dieser Sprache annehmen. Die religiösen Texte zählen zur gehobenen Literatur und unterscheiden sich von der gesprochenen Sprache im bewußten Gebrauch von Partizipialund Gerundialkonstruktionen, welche der alltäglichen Rede fremd waren. Es handelt

skladenjska analiza glagola v Kremplovih Dogodivščinah štajerske zemlje, Diplomarbeit, Ljubljana 1983).

16 In der Tabelle geht es um eine Anzahlübersicht von Partizipien (p) und Gerundien ( $g$ ), exzerpiert aus 700 Textseiten $(p / 700, g / 700)$, ebenso aber auch um eine Durchschnittsanzahl der auf zehn Textseiten gebrauchten Partizipien $(\mathrm{dp} / 10, \mathrm{dg} / 10)$; ersichtlich ist weiter die Gesamtanzahl der auf 700 Textseiten vorkommenden Partizipialkonstruktionen $(\mathrm{pg} / 700)$ und ihre Durchschnittsverwendung pro zehn Seiten (pg/10). 
sich dabei um typische schriftsprachliche Elemente, und es ist verständlich, daß sie zur Entstehungszeit der schriftsprachlichen Norm in Prekmurje so oft verwendet wurden, schließlich waren die Formen auf -č und -ši auch im benachbarten Kajkavischen, in der tschechischen, slowakischen und glagolitischen Literatur sowie auch in der Sprache der Slawenapostel Kyrill und Methodius bekannt. Jedoch waren die -ši-Formen in Prekmurje nicht so weit verbreitet wie etwa bei Š. Küzmič: Das gilt für die Entstehungszeit der prekmurjischen religiösen Literatur und für die Anfänge in der prekmurjischen Publizistik und Belletristik. In dieser Hinsicht müssen wir auch im zentralslowenischen Raum auf einige Verfasser der religiösen Schriften aufmerksam machen, denn auch sie versuchten, obwohl nur ausnahmsweise, die betreffenden Partizipien, öfter als sonst in diesem Raum üblich, zu gebrauchen.

Tabelle 3: Durchschnittshäufigkeit der Partizipial- und Gerundialkonstruktionen auf -č und -ši bei einzelnen Verfassern ${ }^{17}$

\begin{tabular}{|c|c|c|c|c|c|c|}
\hline \multicolumn{7}{|c|}{ Ostslowenischer Sprachraum } \\
\hline \multirow{3}{*}{$\begin{array}{l}\text { Verfasser } \\
\text { Š. Küzmič }\end{array}$} & \multirow{3}{*}{\begin{tabular}{|l|} 
Titel \\
Nouvi zákon, 1771 \\
\end{tabular}} & \multirow{3}{*}{\begin{tabular}{|c|}
$\mathrm{pg} / 100$ \\
371 \\
\end{tabular}} & \multirow{2}{*}{\multicolumn{2}{|c|}{ Partizip }} & \multirow{2}{*}{\multicolumn{2}{|c|}{$\begin{array}{l}\text { Gerundium } \\
-\check{c} \quad-\check{s} \mathbf{i} \\
\end{array}$}} \\
\hline & & & & & & \\
\hline & & & 170 & 9 & 120 & 72 \\
\hline M. Küzmič & Szvéti evangyeliomi, 1781 & 373 & 204 & 10 & 89 & 70 \\
\hline M. Küzmič & Kniga molitvena, 1783 & 36 & 22 & 1 & 8 & 5 \\
\hline M. Bakoš & Nouvi Gráduvál, 1789 & 45 & 21 & 0 & 20 & 4 \\
\hline M. Barla & $\begin{array}{l}\text { Diktomszke, versuske/.../, } 1820 \\
\text { Krscanszke nove peszmene/.../, } 1823\end{array}$ & 61 & 20 & 0 & 29 & 12 \\
\hline J. Kardoš & $\begin{array}{l}\text { Krátki návuk krsztsansztva, } 1823 \\
\text { Nôve knige cstenyá } / . . /, 1870\end{array}$ & $\begin{array}{r}16 \\
(80) \\
\end{array}$ & 15 & 0 & 1 & 0 \\
\hline S. Terplan & Knigé zoltarszke, 1848 & $50(40)$ & 27 & 1 & 21 & 1 \\
\hline Š. Borovnjak & $\begin{array}{l}\text { Angelska služba, } 1890 \\
\text { Mali katekizem, } 1880\end{array}$ & $\begin{array}{r}11 \\
(20)\end{array}$ & 7 & 0 & 4 & 0 \\
\hline R. Cipot & Predga 1888-ga leta, 1888 & $3(13)$ & 2 & 0 & 1 & 0 \\
\hline Publizistik & $\begin{array}{l}\text { Prijátel, Marijin list, Dober pajdás, } \\
\text { Novine }\end{array}$ & $91(47)$ & 43 & 4 & 17 & 27 \\
\hline \multirow[t]{2}{*}{ Gesamt } & & \multirow{2}{*}{$\begin{array}{r}1057 \\
(700) \\
\end{array}$} & 531 & 25 & 310 & 191 \\
\hline & & & \multicolumn{2}{|c|}{565} & \multicolumn{2}{|c|}{501} \\
\hline
\end{tabular}

17 Es geht um eine Übersicht über die Gebrauchshäufigkeit der Formen auf -č und -ši bei den Verfassern der religiösen Literatur im ost- und zentralslowenischen Sprachraum. In der ersten Spalte (pg/100) ist die Gesamtanzahl der Partizipialkonstruktionen auf -č und -ši pro 100 Textseiten ersichtlich; wenn der untersuchte Text weniger als 100 Seiten umfaßt, gibt es rechts in den Klammern die Anzahl der exzerpierten Textseiten /16(80)/. In der zweiten und dritten Spalte wird die Gebrauchshäufigkeit von einzelnen Partizipialkonstruktionen dargestellt. 


\begin{tabular}{|c|c|c|c|c|c|c|}
\hline \multicolumn{7}{|c|}{ Zentralslowenischer Sprachraum } \\
\hline \multirow[t]{2}{*}{ Verfasser } & \multirow[t]{2}{*}{ Titel } & \multirow[t]{2}{*}{$\mathrm{pg} / 100$} & \multicolumn{2}{|c|}{ Partizip } & \multicolumn{2}{|c|}{ Gerundium } \\
\hline & & & $-\check{c}$ & & $-\check{c}$ & - ši \\
\hline U. Jarnik & Jedro kershanskih resnic, 1820 & 77 & 50 & 3 & 15 & 9 \\
\hline F. Veriti & Shivljenje Svetnikov $/ . . /, 1828$ & $15(50)$ & 11 & 0 & 4 & 0 \\
\hline $\mathrm{NN}$ & Evangeliji in branje $/ . . /, 1839$ & $8(50)$ & 3 & 0 & 5 & 0 \\
\hline F. S. Metelko & $\begin{array}{l}\text { Raslaganje svetiga } \\
\text { evangelija/.../,1849 }\end{array}$ & 55 & 32 & 0 & 21 & 2 \\
\hline J. Muršec & Bogočastje /.../, 1850 & 41 & 15 & 4 & 12 & 10 \\
\hline A. A. Wolf & Sveto pismo NZ, 1856 & 24 & 18 & 0 & 6 & 0 \\
\hline L. Jeran & Postne pridige, 1861 & $8(30)$ & 4 & 0 & 4 & 0 \\
\hline A. Lesar & Katekizem / ... $/, 1862$ & $24(30)$ & 7 & 0 & 17 & $\underline{0}$ \\
\hline $\mathrm{NN}$ & Bratovščina $/ . . /, 1881$ & $4(30)$ & 4 & 0 & 0 & 0 \\
\hline F. Marešič & Lurški majnik /.../, 1883 & $11(30)$ & 2 & 0 & 5 & 4 \\
\hline N. Meznarič & Zgodovina /.../, 1884 & $3(30)$ & 2 & 0 & 1 & 0 \\
\hline Publizistik & $\begin{array}{l}\text { Drobtinice, Cvetje z vrtov..., } \\
\text { Duhovni pastir, Angeljček, Zgodnja } \\
\text { danica }\end{array}$ & $\begin{array}{r}85 \\
(80)\end{array}$ & 38 & 1 & 30 & 16 \\
\hline \multirow{2}{*}{\multicolumn{2}{|c|}{ Gesamt }} & 355 & 186 & 8 & 120 & 41 \\
\hline & & $(730)$ & \multicolumn{2}{|c|}{194} & \multicolumn{2}{|c|}{161} \\
\hline
\end{tabular}

Der Durchschnittsgebrauch von Partizipial- und Gerundialkonstruktionen auf -č und -ši im ostslowenischen Raum beträgt 105 (120); davon sind 55 Partizipien (53 auf -č, 2 auf -ši) und 50 Gerundien (31 auf -č, 3 auf -ši). Im zentralslowenischen Raum ist die Durchschnittsfrequenz dieser Formen pro 100 Textseiten deutlich niedriger: von insgesamt 30 (43) Partizipialformen sind 16 Partizipien (15 auf -č, 1 auf -ši) bzw. 13 Gerundien (10 auf -č, 3 auf -ši).

Die Ergebnisse weisen darauf hin, daß die -č- und -ši-Formen in der zentralslowenischen religiösen Literatur im Vergleich zum ostslowenischen Raum viel weniger verwendet wurden: Auf 55 "ostslowenische" Partizipien kommen nur 16 "zentralslowenische" und auf 50 "ostslowenische" Gerundien nur 13 "zentralslowenische". Weiters ist festzustellen, daß die -ši-Formen im zentralslowenischen Raum äußerst selten vorkamen ( $21 \mathrm{im}$ Osten und nur $4 \mathrm{im}$ Zentrum); den meisten Verfassern waren sie nicht mehr geläufig (A. A. Wolf, L. Jeran, A. Lesar, Verfasser von Bratovščina, N. Meznarič, Bearbeiter der Evangelien). Eine Ausnahme in dieser Hinsicht war J. Muršec: Der Gebrauch von -ši-Formen je 100 Seiten ist bei ihm 3,5mal höher als der Durchschnittsgebrauch im zentralslowenischen religiösen Schrifttum (14:4), denn dort fand Ravnikars Begeisterung für die Formen auf -č und -ši keine Verbreitung. ${ }^{18}$ Auch F.

18 Die partizipiale Ausdrucksweise in Ravnikars Zgodbe svetega pisma za mlade ljudi wurde in der Magisterarbeit von M. Jesenšek analysiert (Skladenjski sistem..., 1989, 340-355); demnach werden Ravnikars Texte in der Dissertation nicht erneut ausgewertet. Hier nur einige Daten zum Vergleich: 
Metelko, der in seiner Grammatik (1825) Ravnikars falsche Aspektauffassung korrigierte, entschied sich bei der Bearbeitung des Matthäusevangeliums nicht für die Verwendung der Partizipialkonstruktionen auf -ši . Die Gebrauchshäufigkeit von Partizipialkonstruktionen auf -č und -ši liegt bei ihm zwar höher als im Durchschnitt (55 : 30), jedoch ist sie nicht den -š-Formen zuzuschreiben, da sie nur zweimal vorkommen. Es ist evident, daß diese in der religiösen Literatur des zentralslowenischen Sprachraumes eine seltene Erscheinung waren, und daß dort von ihrer Wiederbelebung wohl nicht die Rede sein kann, mit der Ausnahme einiger Autoren (z. B. U. Jarnik, M. Ravnikar, J. Muršec), die sie ausnahmsweise verwendeten.

Auch im ostslowenischen Sprachraum waren sich die Verfasser der religiösen Schriften im Gebrauch der Formen auf -č und -ši nicht einig. Am häufigsten verwendet sie Š. Küzmič; bei ihm treten sie 3,4mal öfter als durchschnittlich auf (371:108). In bezug auf die Partizipien bzw. Gerundien entspricht das einem Verhältnis von fast $1: 1$ (179 : 192). Unter den Partizipien überwiegen die Formen auf -č (95\%), während unter den Gerundien das Verhältnis zwischen den -č- und -ši-Formen ausgewogener ist (65\% auf $-\check{c}, 37,5 \%$ auf -ši). Sämtliche Neuauflagen des Nouvi zakon im 19. Jahrhundert weisen dieselbe Gebrauchshäufigkeit der Partizipialkonstruktionen auf -č und ši auf; ${ }^{19}$ demnach sollte diese Ausdrucksart syntaktischer Verhältnisse trotz seiner abnehmenden Gebrauchshäufigkeit die Schriftsprache beeinflußt haben. Der Anteil an -ši-Formen im Partizipialsystem der ostslowenischen religiösen Literatur blieb interessanterweise jenem bei Š. Küzmič gleich $(38,1 \%) ;{ }^{20}$ der Anteil an Gerundien auf -ši bei Š. Küzmič liegt bei $19,4 \%$ und beträgt für die gesamtslowenische religiöse Literatur $17,6 \%$. Ähnlich wie bei Š. Küzmič erscheinen die Partizipialkonstruktionen auch bei $\mathrm{M}$. Küzmič, jedoch nur in Evangelien (Szveti evangyeliomi). ${ }^{21}$ In Kniga molitvena hingegen werden die Formen auf -č und -ši sogar seltener verwendet als durchschnit-

Ravnikar gebraucht 209 Partizipialkonstruktionen auf -č und -ši je 100 Seiten, und zwar 99

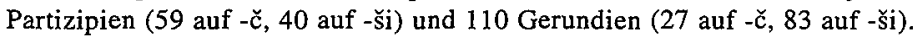

19 Die Feststellung basiert auf einer Analyse der Neuausgaben aus den Jahren 1817, 1848 und 1883 (Terplans bearbeitete Fassung); dasselbe System der Partizipial- und Gerundialkonstruktionen blieb aber auch in der Ausgabe aus dem Jahr 1928 erhalten.

20 Ein stark verändertes Verhältnis ist bei M. Ravnikar zu konstatieren, denn von Nouvi zakon übernahm er unkritisch vor allem die Formen auf -ši. Im Vergleich mit S̆. Küzmič verwendet er die Partizipialkonstruktionen auf -č und -ši nicht so oft (371:209), was aber dem selteneren Gebrauch

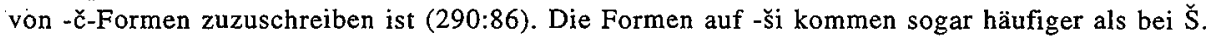
Küzmič vor (81:123); hauptsächlich sind das Partizipien auf -ši (9:40). Die -ši-Formen als Gerundien treten dagegen bei Ravnikar nur 1,15mal öfter auf (72:83), obgleich sie 39,7\% aller Partizipial- und Gerundialkonstruktionen auf -č und -ši in Zgodbe svetega pisma za mlade ljudi ausmachen (bei Š. Küzmič 19,4\%).

21 Eine vergleichende Untersuchung mehrerer Ausgaben (Neudruck 1804, 6. Auflage um 1845, 10. Auflage 1879, 11. Auflage 1885, Borovnjaks Bearbeitung) ergab keine Veränderungen beim Gebrauch von -č- und -ši-Formen. 
tlich in der gesamten religiösen Literatur des 19 . Jahrhunderts $(36: 58){ }^{22}$ Trotzdem ist aber der Gebrauch von -č- und -ši-Formen in dem ältesten katholischen Gebetbuch in Prekmurje der Beweis dafür, daß es sich dabei um autochtone morphologisch-syntaktische Elemente handelt, die sich gerade in alten Gebetsformeln des pannonischen Sprachraumes erhalten haben. ${ }^{23}$ Von hier aus verbreiteten sie sich überall in den prekmurjischen Schriften und wurden zu einem Merkmal des gehobenen Sprachstils der Schriftsprache in Prekmurje - ein deutlicher Unterschied gegenüber der gesprochenen Sprache. Die Gebrauchshäufigkeit der Partizipial- und Gerundialkonstruktionen auf - $\check{c}$ und -ši ist (außer bei M. und Š. Küzmič) hauptsächlich in der Sprache von A. Terplan zu beobachten; in erster Linie hielt er sich an die damalige schriftsprachliche Tradition, mit der er sich bei der Bearbeitung von Nouvi zakon vertraut gemacht hatte. ${ }^{24}$ In seiner Übersetzung der Psalmen (Knige 'zoltarske) ist aber trotzdem eine deutlich geringere Frequenz der -ši-Formen festzustellen. Am häufigsten kommen sie in den Barlas $\mathrm{Ge}-$ sangbüchern vor, da er sich bewußt bemühte, die kajkavischen Formen zu vermeiden; ${ }^{25}$ in dieser Hinsicht unterscheidet sich seine Sprache von jener des Bakoš wesentlich. Die Partizipial- und Gerundialkonstruktionen auf -č und -ši verwendet M. Barla häufiger als M. Bakoš (61 : 45), was vor allem auf die häufige Verwendung von Gerundien (41:24) zurückzuführen ist, insbesondere von Formen auf -ši (12:4). Von der Bemerkung Novaks über das bewußte Vermeiden der kajkavischen Elemente bei Barla ausgehend und unter Berücksichtigung der geringen Geläufigkeit der -ši-Formen in der kajkavischen Schriftsprache bereits bei Krajačevic ${ }^{26}$ können wir feststellen, daß der häufige Gebrauch der -ši-Formen in Barlas Gesangbüchern die These über die autochtonen Gerundien im pannonischen Sprachraum bestätigt. Ohne Zweifel waren diese auch im Kajkavischen bekannt, jedoch wurden sie in der Schriftsprache der prekmurjischen Ver-

Dabei wurden die Neuausgaben von Nouvi zakon und Szveti evangyeliomi nicht berücksichtigt.

"Tako je ta knjiga $z$ besedili in jezikom vez med stoletji brez tiska, iz katerih je mnogo povzela, kakor tudi iz kajkavskih molitvenikov." (V. Novak: Izbor prekmurskega slovstva, Ljubljana 1976, 57). Gerade die "Überbrückung der Jahrhunderte ohne Buchdruck", die in der lexikalischen und morphologisch-syntaktischen Prägung der "altslowenischen" Ritualtexte ihren Ausdruck findet, können wir einen Nachweis für eine "alte slowenische Sprache" finden. Im pannonischen Raum bewahrte diese Sprache ihre altkirchenslawische Tradition und unterschied sich bewußt von der verwandten kajkavischen "slowenischen" Sprache. Die kajkavischen Einflüsse haben dabei nur eine sekundäre Bedeutung; interessant sind sie aufgrund der politisch-administrativen und historisch-geographischen Einteilung in Prekmurje. Auch M. Küzmič war sich der Tatsache bewußt, daß das Kajkavische nicht die Sprache der Slowenen in Prekmurje sein kann. Im Jahr 1785 verlangte er sogar (das ist aus seinem lateinischen Brief an den Bischof Szily ersichtlich), daß der Pfarrer in Bogojina (sonst ein Kajkave) slowenisch erlernt. Es geht wiederum um einen deutlichen Beweis für die Existenz einer eigenen Schriftsprache in Prekmurje.

J. Novak: Izbor prekmurskega slovstva, Ljubljana 1976, 73-74.

Ibd., 69.

Vgl. dazu die Magisterarbeit von M. Jesenšek, und zwar das Kapitel Skladenjski sistem aktivnih deležniških oblik v vzhodnoslovenskem in kajkavskem knjižnem jeziku, 384-414. 
fasser nicht als Fremdelemente bzw. als kajkavische Lehnübersetzungen empfunden, sondern sie galten als vertraute syntaktische Mittel in der ritualsprachlichen Tradition des "Altslowenischen". Besonders wichtig war diese Tradition für M. Barla, da er im Ausland lebte, ${ }^{27}$ aber auch für seine Zeitgenossen in Prekmurje, da die Formen auf - $\check{c}$ und -ši in der gesprochenen Sprache nicht mehr üblich waren. Der Protestant J. Kardoš und Š. Borovnjak, ein Katholiker, verwendeten die -ši-Formen in einigen ihrer Schriften überhapt nicht mehr. Š. Borovnjak war Bearbeiter und Herausgeber von M. Küzmičs Werken; hier wurden die -č- und -ši-Formen meist beibehalten, während sie in freieren Bearbeitungen (Mali katekizem za občinske lüdske šole, Angelska služba) nicht mehr vorkommen. Angelska služba (um 1890) gilt als Erstdruck eines prekmurjischen Verfassers in "neuslowenischer" Schriftsprache; auf 16 Textseiten sind nur zwei Gerundien auf -č (klischeehaftes rekoč) und ein im Osten sonst unbekanntes Partizip auf -e (trkaje) zu finden. Der Anteil an -ši-Formen in den Belegen aus der Publizistik beträgt sogar 34,7\% (4 Partizipien und 27 Gerundien), d.h. zweimal höher als ihre Durchschnittshäufigkeit in der religiösen Literatur $(17,6 \%)$. Die ausgewertete Zeitschrift Prijatel galt jedoch nicht als "religiös"; ${ }^{28}$ der Redakteur der Zeitschrift Dobri pajdaš war J. Pustai, ein Katholiker und Lehrer, ihr Inhalt war aber eher profaner Art; ähnlich auch Novine (redigiert vom Pfarrer J. Klekl sen.) mit einem geringen Anteil religiöser Texte. Echte religiöse Inhalte brachte lediglich Marijin list (der erste Redakteur J. Klekl sen.), wo aber die -ši-Formen selten gebraucht wurden. Es sind durchschnittlich 14 Partizipialkonstruktionen pro Zeitschriftnummer festzustellen: 10 davon sind Partizipien (alle auf -č) und 4 Gerundien (je 2 auf -č bzw. -ši). Der Anteil an -ši-Formen sank demnach wesentlich $(14,39 \%)$.

Es ist charakteristisch, daß die Partizipial- und Gerundialkonstruktionen auf - $\check{c}$ und -ši in der slowenischen religiösen Literatur im Osten häufig und im Zentrum selten vorkommen. Im Zentrum wurden sie meist nur von einigen Bewegungsverben bzw. von den Verben des Sprechens und sinnlicher Wahrnehmung gebildet und als syntaktisches Klischee in allen Texten verwendet. ${ }^{29}$ Seltene Abweichungen von solchen Verwendungs-

V. Novak konstatiert, daß M. Barla "in der Literatur noch völlig unerforscht" ist. Außer den slowenischen Schriften zu diesem Thema (J. Šlebinger, J. Flisar) zitiert er die ungarische Literatur über seine Ausbildung in Jena, über seine Arbeit als Schulleiter in Szentlörinc und über seine evangelische Tätigkeit in Kövágóörs in der Nähe des Balatonsees, wo er auch gestorben ist. Vgl. V. Novak, 69, 184. Es ist daraus ersichtlich, daß Barla zwar nicht in Prekmurje lebte, den Kontakt mit der prekmurjischen Sprache jedoch nicht verlor. Es soll sogar eine Grammatik geschrieben haben, von der aber kein Exemplar erhalten geblieben sei (69).

Ihr Redakteur J. Agustich war kein Pfarrer, sondern der erste Journalist in Prekmurje. Vgl. V. Novak, 81.

In ob deveti uri je Jezus z velíkim glasom zavpil, REKOČ: Eloj, Eloj! lama sabáktani? (A. Wolf, Sv. pismo nove zaveze 1956, Mat. 9,23.) V cerkev STOPIVŠI poškropi se, REKOČ: Poškropi me, o Gospod! (N. Meznarič, Pot v nebesa ali življenje udov III. reda sv. Frančiška /.../, 1884, 260). Dva uzhenza GREDOZH v Emaus nista mogla od drugiga govoriti, ko od Jesufa, ker Sta ga ljubila. (F. Veriti, Življenje svetnikov in preftavni godovi $I, 1928,13$.) 
weisen (wie etwa bei M. Ravnikar, U. Jarnik, J. Muršec) beeinflußten den allgemeinen Gebrauch von Partizipien nicht; vor allem die -ši-Formen wurden in der religiösen Literatur zentralslowenischer Prägung nicht aufgenommen. Die alte schriftsprachliche Tradition im zentralslowenischen Alpenraum verdrängte die Partizipialkonstruktionen auf -č und -ši schon frühzeitig und ersetzte sie durch andere syntaktische Möglichkeiten. Die zentralslowenische religiöse Literatur des 19. Jahrhunderts blieb in der Verwendung der Partizipialkonstruktionen auf -č und -ši mit der gesprochenen Sprache verbunden; im morphologisch-syntaktischen Sinne zeigte sie das Bild einer um die Jahrhundertwende geformten slowenischen Sprache, in der die Partizipialkonstruktionen auf -ši nicht usuell waren. Es scheiterten alle Versuche, diese Formen im zentralslowenischen Sprachraum sowie auch in den slowenischen Dialekten wiederzubeleben. Ihr seltener Gebrauch war stilistisch markiert und wirkte archaisch.

Stilistisch markiert war die Verwendung von -č- und -ši-Formen allerdings auch im ostslowenischen Sprachraum. Hier dienten diese Formen als stilistische Merkmale einer Schriftsprache, da sie nur in geschriebener Form erschienen. In der geschriebenen slowenischen Schriftsprache sind diese archaischen slawischen Formen kontinuierlich zu beobachten. Im pannonischen Sprachraum waren sie bereits in der pannonischen Variante des Altkirchenslawischen bekannt. Im 19. Jahrhundert wurden die Formen auf -č und -ši nicht nur in der pannonischen religiösen Literatur geläufig, sondern sie verbreiteten sich auch im zentralslowenischen Sprachraum und wurden in die "neue gesamtslowenische" Schriftsprache der zweiten Hälfte des 19. Jahrhunderts aufgenommen. Sie fungierten in allen Stilschichten als typisch schriftsprachliche morphologischsyntaktische Kategorie, jedoch erreichten sie (mit der Ausnahme jener bei F. Levstik) die für die prekmurjische religiöse Literatur charakteristische Gebrauchshäufigkeit nicht.

\subsection{Profane Literatur}

In bezug auf die Verwendung der -č- und -ši-Formen in der profanen Literatur im ost- und zentralslowenischen Sprachraum sind keine wesentlichen Unterschiede festzustellen. Vor allem gilt das für Belletristik, denn hier wurden die betreffenden Formen häufig gebraucht und von den Autoren nicht vermieden, wie etwa in der religiösen Literatur. Verbreitet waren sie in allen Textsorten, jedoch sind Unterschiede in der Gebrauchshäufigkeit bei einzelnen Verfassern nicht zu übersehen. Diese beruhen auf mehr oder weniger kultiviertem Sprachgebrauch bei den Übersetzern, während die Dichter, Schriftsteller und Dramatiker gerade am Gebrauch der -č- und -ši-Formen erkennbar sind. Die Frequenz dieser Formen war vom jeweiligen syntaktischen Sprachstil geprägt, welcher mehr oder weniger originell ist. Die Gebrauchshäufigkeit der Partizipialkonstruktionen auf -č und -ši in nichtbelletristischen Texten, vor allem in publizistischen und fachlichen Textsorten (die Textsorten der alltäglichen Kommunikation des 19. Jahrhunderts in der Entwicklung noch ziemlich zurückgeblieben ${ }^{30}$ ) ist in Abhängigkeit 
von sprachlicher Ausbildung und der Fähigkeit einzelner Autoren zu interpretieren, sämtliche morphologisch-syntaktischen Möglichkeiten der Formen auf $-\check{c}$ und -ši auszuschöpfen, welche in zahlreichen Grammatiken der slowenischen Sprache im 19. Jahrhundert normativ festgelegt waren. Lediglich Levstik übernahm sie im ganzen, während sich die übrigen Autoren dieser Zeit mehr oder weniger erfolgreich über den Gebrauch dieser originellen altkirchenslawischen Formen informierten. Die Versuche, die Formen auf -č und -ši wieder im Gebrauch zu festigen, erfolgten am Anfang ziemlich zwanghaft (M. Ravnikar), nachdem aber die schriftliche Norm von den Grammatikern (zuerst von F. Metelko) festgelegt worden war, wurden diese morphologisch-syntaktischen Mittel, welche den Satz so schön verkürzen, von den meisten slowenischen Autoren akzeptiert. Obwohl oft gebraucht blieben sie aber auf die geschriebenen Texte beschränkt; in der gesprochenen Sprache fanden sie selten Verwendung, da hier einfach zusammengesetzte Sätze und eine lockere Abstimmung von phonetischen Konstruktionen überwogen.

Die Gebrauchshäufigkeit der -č- und -ši-Formen in der slowenischsprachigen profanen Literatur wird einerseits funktionalstilistisch (literarische vs. sonstige Texte) und andererseits historisch (sechs Entwicklungsphasen der - ̌̌- und -ši-Formen in der slowenischen Schriftsprache des 19. Jahrhunderts) analysiert. Bei der letzteren Darstellungsweise ist die Spaltung des slowenischen Sprachraumes nicht mehr notwendig, da (nach Metelko) in der dritten Entwicklungsphase die untersuchten Formen auch im zentralslowenischen Raum verbreitet waren. Die zentralslowenische Variante der Schriftsprache wurde in der Mitte des 19. Jahrhunderts unter Berücksichtigung morphologisch-syntaktischer Möglichkeiten des Ostslowenischen zu einer einheitlichen slowenischen Schriftsprache. An dieser Stelle wird deshalb nur die Gesamtzahl der exzerpierten Partizipial- und Gerundialkonstruktionen angegeben und der Prozentsatz der aus dem ost- und/oder zentralslowenischen Sprachraum stammenden -č- und -ši-Formen hinzugefügt. Es muß dabei berücksichtigt werden, daß die Anzahl der aus dem ostslowenischen Raum stamenden Belege zwölffach geringer ist als diejenige aus dem zentralslowenischen und daß alle nichtprekmurjischen, jedoch in der "neuslowenischen" Schriftsprache verfaßten Buchausgaben zum zentralslowenischen Schrifttum gezählt worden sind:

Darauf verweist u.a. J. Toporišič; den Funktionalstil der Alltagsrede betrachtet er als Ausgangsbasis, von der die Entwicklung der künstlerischen, fachlichen und publizistischen Texte ausgeht ("Vse tri neprvotne funkcijske zvrsti /umetnostna, strokovna, publicistična/ imajo dokaj obsežno stično ploskev s PS /praktičnim sporazumevanjem/, med seboj pa manjšo /.../") Den Funktionalstil der Alltagsrede sieht er einerseits "v glavnem $v$ okviru oficialnega družbenega stika $/ . . . /$, pa še tam ne zmeraj", andererseits aber auch im Rahmen der künstlerischen Texte, falls diese keine umgangssprachlichen und/oder dialektalen Elemente aufweisen (vgl. die Abhandlung Toporišičs in Slavistična revija 40/1992, Tipološka oznaka (sodobnega) slovenskega knjižnega jezika, 170-172). 
Tabelle 4

\begin{tabular}{|c|c|c|c|c|c|c|}
\hline \multicolumn{7}{|c|}{ Profane Literatur } \\
\hline \multirow[t]{2}{*}{ Sprachraum } & \multirow{2}{*}{$\begin{array}{c}\text { Gesamtanzahl der } \\
\text { exzerpierten } \\
\text { Formen auf } \\
\text { - } \breve{c},- \text { ši },-/ a j / e\end{array}$} & \multicolumn{2}{|c|}{ Partizip auf } & \multicolumn{3}{|c|}{ Gerundium auf } \\
\hline & & $-\check{c}$ & $-s ̌ \mathrm{i}$ & $-\check{\mathrm{c}}$ & $-s ̌ \mathrm{i}$ & - - /aj/e \\
\hline Ostslowenisch & 337 & $30,56 \%$ & $2,62 \%$ & $37,68 \%$ & $29,14 \%$ & 1 \\
\hline Zentralslowenisch & 3945 & $26,86 \%$ & $1,72 \%$ & $29,56 \%$ & $27,74 \%$ & $11,12 \%$ \\
\hline
\end{tabular}

Es ist evident, daß die Formen auf -č und -ši im ost- und zentralslowenischen Sprachraum beinahe verhältnisgleich vorkommen. Ein geringerer Prozentsatz ist lediglich bei den Partizipialkonstruktionen auf -č festzustellen, jedoch nur wegen der Formen auf -/aj/e, welche im Osten nicht geläufig waren; allerdings ist ein seltener Gebrauch der Partizipien auf -ši auf dem gesamtslowenischen Sprachgebiet zu konstatieren.

Ein Vergleich mit der religösen Literatur ist aufgrund der identischen Statistik möglich, allerdings sind diese Daten nicht so zuverlässig wie etwa die Gebrauchshäufigkeitsanalyse von Partizipial- und Gerundialkonstruktionen auf -č und -ši im vorigen Kapitel. Trotzdem ist eine beträchtliche Zunahme der verbal gebrauchten Partizipien auf -ši in der profanen Literatur anzunehmen: im Osten beträgt sie 8,95\% $(20,19 \%: 29,14 \%)$ und im Zentrum sogar $17,72 \%$ (10,02\%: 27,74\%). Falls im Rahmen der zentralslowenischen religiösen Literatur der Gebrauch von Gerundien auf -ši bei J. Muršec nicht berücksichtigt worden wäre, wäre der Anteil von Gerundien auf -ši an der Gesamtanzahl der Partizipialkonstruktionen prozentual noch niedriger (4,8\%). Der Anteil der Partizipien auf -ši ist nur wenig gestiegen, im Osten von $2,1 \%$ auf $2,62 \%$, und im Zentrum von $0,95 \%$ auf $1,72 \%$. Öfter gebraucht wurden auch die Formen auf -/aj/e $(3,93 \%: 14,12 \%)$, weswegen die Verwendung von -č-Formen in der zentralslowenischen profanen Literatur fast um die Hälfte gesunken ist (Partizipien 26,86\% : 53,6\%, Gerundien $29,56 \%: 31,5 \%$ ). Eine solche Statistik soll allerdings nur als Orientierung verstanden werden, denn sie stellt die Prozentwerte aufgrund der exzerpierten Belege dar. Dabei wurden das umfangsmäßig differente Sprachmaterial bei einzelnen Autoren, ebenso aber auch verschiedene Textgattungen und Entstehungszeiten nicht berücksichtigt. Unter Einbeziehung von letztgenannten Kategorien könnten sich die dargestellten Verhältnisse im Gebrauch von Partizipial- und Gerundialkonstruktionen auf $-\check{c}$ und $-\check{s} i$ in der slowenischen Schriftsprache des 19. Jahrhunderts auch ändern. 


\section{Funktionalstilistische Distribution der untersuchten Partizipial- und Gerundiallkonstruktionen}

In diesem Kapitel wird die Gebrauchshäufigkeit von Partizipial- und Gerundialkonstruktionen auf $-\breve{c}$ und $-\check{s} i$ in der slowenischen Schriftsprache des 19. Jahrhunderts hinsichtlich ihrer Funktionalität in unterschiedlichen Kommunikationsbereichen dargestellt. ${ }^{31}$ Die Formen auf č- und -ši wurden nicht nur in der ostslowenischen religiösen Literatur verwendet, sondern sie verbreiteten sich zuerst in belletristischen, später auch in sonstigen Texten. Besonders stark beeinflußten ihre Gebrauchshäufigkeit in den belletristischen Texten Übersetzungen aus slawischen Sprachen; ebenso stark vertreten waren sie in der heimischen Literatur (haupsächlich gilt das für die Epik, weniger aber für Lyrik bzw. Dramatik). Von einigen Zeitungsnachrichten abgesehen, wurden in die Untersuchungen keine Texte der alltäglichen Kommunikation einbezogen, da diese Textsorten in der Schriftsprache des 19. Jahrhunderts erst am Anfang ihrer Entwicklung standen ${ }^{32}$ und demnach keine wesentliche Wirkung auf die Verwendung von -č- und -ši-Formen hatten. Nicht einmal die Übersetzung von Državni zakonik (Staatsrecht) wirkte diesbezüglich maßgeblich, obwohl hier die neuen Formen erfolgreich in die slowenische Amtssprache, welche später für die Lehrbuicher normativ war, eingesetzt wurden, ${ }^{33}$ denn der Redakteur M. Cigale war gegen die partizipiale Ausdrucksweise eingestellt. ${ }^{34}$ Der fachsprachliche Gebrauch von Formen auf -č und -ši wird im Rahmen der belehrenden Texte und Amtstexte, sowie im Rahmen der populärwissenschaftlichen (Lehrbücher, Lebenslauf) und wissenschaftlichen Texte dargestellt. Der Sprachgebrauch in der Publizistik wird mit den Belegen aus den relevantesten

31 Die verwendete funktionalstilistische Einteilung des Slowenischen bewahrt die entsprechende Einteilung bei J. Toporišič (vgl. seine Grammatik Slovenska slovnica, Maribor 1976, 21-26 bzw. seine Abhandlung Tipološka oznaka (sodobnega) slovenskega jezika. In: Slavistična revija 40/1992, 170-172) und befolgt die Klassifizierung in Slovenska zvrstna besedila (Ljubljana 1981), herausgearbeitet von J. Toporišič und V. Gjurin.

32 Vgl. M. Orožen: Uradovalna slovenščina v drugi polovici 18. stoletja. In: Obdobja 1, 155-182. Ljubljana.

33 A. Breznik: Razvoj novejše slovenske pisave pa Levčev pravopis. In: A. Breznik, Jezikoslovne razprave (hrsg. von J. Toporišič), Ljubljana 1982, 87-88.

34 Die Partizipien fanden auch in der Zeitschrift Slovenija (Redakteur M. Cigale) äußerst selten Verwendung. 1849 veröffentlichte sie eine Gesetzsammlung (Knjiga splošnih deržavljanskih postav), wo statt Partizipien Nebensätze zu finden sind. Trotzdem sind einige -ši-Formen in Državni zakonik doch zu finden; in den 50er Jahren waren diese in der belletristischen Literatur bereits weit verbreitet (Ker smo že $v$ vodilih, ki smo jih v Naših sklepih 31. decembra 1851 vstanovili za organsko postavodajo cesarstva, bili zavkazali, da naj se kazenski postavi moč v celem Našem cesarstvu da, zapovemo ZASLIŠAVŠI Naše ministre in naše deržavno svetovanstvo, kakor sledi:.../. POČEMŠI od ravno tega dne naj nazoča kazenska postava glede na kaznjive dejanja, ki so v njej za hudodelstva, pregreške ali prestopke izrečene, tudi tikrat velja za vodilo, kadar so se te dejanja po tiskopisih doprinesle. Vgl. Teil XXXVI des Državni zakonik, hrsg. am 31. Juli 1852, und zwar kaiserliches Patent Nr. 117 - Einleitung und Artikel 1). 
slowenischen Zeitschriften des 19. Jahrhunderts illustriert (dabei wurden 36 Titel ausgewertet), jedoch sind viele davon literarische Zeitschriften, denn eine Verflechtung von literarischen und nichtliterarischen Texten in den Zeitschriften des 19. Jahrhunderts war bereits seit Novice (Bleiweis) durchaus üblich. Es wurden in der Regel sämtliche vier Funktionalstile der slowenischen Schriftsprache einbezogen, und nur selten überwogen die verschiedenartigen publizistischen Textsorten mit ihrer primär vermittelnden Funktion. Eher war es umgekehrt: Die slowenischen Zeitungen, Zeitschriften und Sammelbände waren meist so konzipiert, daß die publizistischen Texte (im 19. Jahrhundert erst in Ansätzen) im Hintergrund standen.

\subsection{Literarische Texte}

Die Wiederbelebung von Partizipial- und Gerundialkonstruktionen auf -č und -ši in den literarischen Texten des 19. Jahrhunderts resultiert aus der Begegnung zweier morphologisch-syntaktischer Varianten der slowenischen Schriftsprache in der ersten Hälfte des 19. Jahrhunderts. Im Zentrum des slowenischsprachigen Gebietes wurden vom 16. bis 19. Jahrhundert die Partizipien (vor allem die Formen auf -ši) oft durch finite Verbformen ersetzt, denn bei den -č- und -ši-Formen war im Alpenraum seit der Zeit der Freisinger Denkmäler ihre rechte Valenz meist verlorengegangen; demzufolge wurden diese Formen zu Adverbien. Die ostlowenische, auf der pannonischen Tradition basierende Variante der Schriftsprache bewahrte hingegen die altkirchenslawische partizipiale Ausdrucksweise. Noch am Ende des 18. und am Anfang des 19. Jahrhunderts waren die -č- und -ši-Formen funktional stark differenziert: Man unterschied in Genus und Kasus bzw. in Genus und Numerus flektierbare Formen in der attributiven und/oder prädikativen Funktion einerseits und satzwertige Partizipialkonstruktionen, welche die langen und komplizierten Satzverbindungen erfolgreich komprimierten, andererseits. Gebraucht wurden die verschiedenartigen Partizipien lediglich in der geschriebenen Sprache; demnach zeugten sie von der sprachlichen Kultiviertheit des Verfassers sowie von seiner Beherrschung der sprachlichen Norm. Dadurch wurde der Sprachgebrauch in der geschriebenen Sprache von der einfachen Rede im Dialekt deutlich abgehoben. Die Partizipial- und Gerundialkonstruktionen auf -č und -ši waren auch in der ostslowenischen Variante des Slowenischen auf die Schriftsprache beschränkt, und blieben es auch in den literarischen Texten des 19. Jahrhunderts.

Die -č- und -ši-Formen wurden in die slowenische Belletristik unter dem Einfluß der prekmurjischen religiösen Literatur übernommen. Allerdings gaschah das nicht direkt wie etwa im zentralslowenischen religiösen Schrifttum. Die Verwendung dieser Formen war normativ vorgeschrieben, nachdem die partizipialen Formen in slowenischen Grammatiken morphologisch und syntaktisch wiederbelebt und vorgeschlagen worden waren. ${ }^{35}$ Zuerst geschah das in der Grammatik von F. Metelko (1825), die von 
den weiteren Grammatiken in der ersten Hälfte des 19. Jahrhunderts in bezug auf den Gebrauch von Partizipialformen oft nachgeahmt wurde; vor allem gilt das aber für die Grammatik von A. Janežič (1854, zweite Ausgabe 1863) und F. Levstik (1866). Janežičs Grammatik war ein Lehrbuch für die Vertreter des slowenischen "romantischen Realismus", und diese nahmen die partizipiale Ausdrucksweise wohlgesonnen an. Die Partizipialkonstruktionen wurden zum typischen Ausdruck der zeitlichen Verhältnisse im Satz (Gerundien), gleichzeitig ermöglichten sie aber auch die sprachliche Verdichtung (Partizipien und/oder Gerundien). Im Sinne der Textformulierung können den Partizipien auch ästhetische Leistungen anerkannt werden. ${ }^{36}$

In der literarischen Sprache des 19. Jahrhunderts fanden die Formen auf -č und -ši weite Verbreitung. Übernommen wurden sie aus der ostslowenischen Schriftsprache, nach dem Vorbild des Altkirchenslawischen wurden sie in den Grammatiken angenommen und den Ausdrücksmöglichkeiten der Belletristik angepaßt, die zu einem höheren Kultivierungsgrad der slowenischen Schriftsprache wesentlich beitrug.

Tabelle 5: Durchschnittshäufigkeit der Partizipial- und Gerundialkonstruktionen auf $-\check{c}$ und -ši in den literarischen Texten

\begin{tabular}{|l|c|c|c|c|c|c|}
\hline \multirow{2}{*}{} & \multicolumn{2}{|c|}{ Partizip } & \multicolumn{2}{c|}{ Gerundium } & \multicolumn{2}{c|}{ Gesamt } \\
\cline { 2 - 7 } & $\mathrm{p} / 700$ & $\mathrm{dp} / 10$ & $\mathrm{~g} / 700$ & $\mathrm{dg} / 10$ & $\mathrm{pg} / 700$ & $\mathrm{pg} / 10$ \\
\hline$-\check{\mathrm{c}}$ & 179 & 2,55 & 164 & 2,34 & 343 & 4,89 \\
\hline -ši & 8 & 0,11 & 182 & 2,6 & 190 & 2,71 \\
\hline -/aj/e & & & 123 & 1,75 & 123 & 1,75 \\
\hline Gesamt & 187 & 2,66 & 469 & 6,69 & 656 & 9,36 \\
\hline
\end{tabular}

übernahm sie unkritisch und gebrauchte sie in Zgodbe svetega pisma za mlade ljudi (1815-1817). Die Formen waren aber nicht entsprechend abgeleitet und erweitert. Daher wurden sie von seinen Zeitgenossen abgelehnt und setzten sich in der zentralslowenischen religiösen Literatur nicht durch. Sie forderten sogar F. Prešeren heraus: Im bekannten Epigramm spottete er über Ravnikars mangelhaftige Kenntnisse über die grammatischen Eigenschaften der -č- und -ši-Formen. Insbesondere wurden diese Formen von Romantikern abgelehnt, denn sie stützten sich auf die volkstümliche Literatur, die sie sogar unter dem Volk sammelten. All das lieferte reichlich Beweise dafür, daß die -č- und -ši-Formen in der mündlichen Tradition des slowenischen Alpenraumes bereits seit der Zeit der fahrenden Sänger nicht geläufig waren. Ravnikars Wiederbelebungsversuche der Partizipialformen wurden aber dennoch nicht übersehen, denn sie weckten das Interesse der Grammatiker, welche eine aspektgerechte Ableitung dieser Formen herausarbeiteten. Vom Zeitgenossen Prešerens J. V. Koseski wurden sie bereits angenommen, und da er ein "Modedichter" war, kamen sie auch in der belletristischen Sprache schnell in Gebrauch.

36 Die ästhetischen Werte der Formen auf -č und -ši spielten bei der Gestaltung der belletristischen Texte eine wichtige Rolle. Darauf verweist E. Dvořak (Přechodnikové konstrukce v nové češtině, Prag 1983, 95); nach dessen Meinung gelte dasselbe auch für das Tschechische, wo diese Formen im 19. Jahrhundert noch frequenter waren als im Slowenischen. 
Die Durchschnittshäufigkeit der Partizipial- und Gerundialkonstruktionen auf $-\check{c}$ und -ši pro zehn Seiten literarischer Texte beträgt 9,36; die Gerundien sind häufiger $(4,94)$ als Partizipien $(2,66)$. Der Anteil der Gerundien wird außerdem durch die Formen auf -/aj/e begünstigt ${ }^{37}(1,75)$, so daß ein Partizip auf 2,51 Gerundien kommt. Die Formen auf -č $(4,89)$ sind zahlreicher als diejenigen auf -ši $(2,71)$ oder -/aj/e $(1,75)$, während die Gerundien auf $-\check{c}$ und -ši fast verhältnisgleich auftreten $(2,34: 2,6)$. Es muß dabei aber berücksichtigt werden, daß die Gleichzeitigkeit auch mit Gerundien auf -/aj/e ausgedrückt wird. Die Häufigkeit der Partizipien auf -č erreicht fast diejenige der Gerundien $(2,55: 2,34)$, äußerst schwach vertreten sind aber die Partizipien auf -ši $(0,11)$.

Aus der Tabelle 5 ist ersichtlich, daß in den literarischen Texten außer den Partizipialkonstruktionen auf -č und -ši auch solche auf -/aj/e vorkommen. Die letzteren waren in der ostslowenischen Schriftsprache nicht bekannt, sie kommen aber in der religiösen Literatur des zentralslowenischen Sprachraums vor. Die Formen auf -/aj/e sind besonders bei J. Vesel Koseski zu finden. Thre Verwendung in der slowenischen Belletristik wurden jedoch insbesondere durch Übersetzungen aus dem Tschechischen und Russischen gefördert. Bis zu den 60er Jahren des 19. Jahrhunderts haben sich diese Formen weit verbreitet und behaupteten sich haupsächlich als syntaktische Synonyme für Gerundien auf $-\check{c}$. Gegen Ende des Jahrhunderts wurden sie unter dem Einfluß der an einer neuen slowenischen Schriftsprache orientierten Generation von I. Cankar allmählich zu departizipialen Adverbien. ${ }^{38}$ Es ist interessant, daß die syntaktische Synonymie der Gerundien auf - $\check{c}$ und -/aj/e in den literarischen Texten eine paralelle Entwicklung und eine fast identische Frequenz der Formen ermöglichte (ein Gerundium auf -/aj/e kommt auf 1,33 solcher auf -č). Demzufolge konnte keine von diesen beiden Formen verallgemeinert werden. $^{39}$

37 In der Tabelle wird lediglich die Häufigkeit von Gleichzeitigkeit ausdrückenden Gerundien auf -/aj/e dargestellt (wie etwa die Gerundien auf -č); departizipiale Adverbien hingegen wurden im Sprachmaterial nicht berücksichtigt.

Über die Wiederbelebung, funktionale Angemessenheit und Verwendung der Formen auf -/aj/e in der slowenischen Schriftsprache vom 16. bis zum 19. Jahrhundert berichtet M. Orožen (Sekundarna derivacija prislovnega deležnika na -e/-aje v slovenskem knjižnem jeziku. In: Nahtigalov zbornik, Ljubljana 1977, 335-356). Im 19. Jahrhundert erscheinen diese Formen wieder bei M. Ravnikar, während sie im ostslowenischen Raum nicht geläufig waren (Allerdings werden sie in der Grammatik und im Wörterbuch von A. Murko zitiert!). Öfter kommen sie in Übersetzungen vor und werden auch in Janežičs Grammatik vorgeschrieben ("Prislovni deležnik sedanjega časa na -e/-aje je $\checkmark$ 60. letih $v$ delih slovenskih pisateljev rabljen že povsem naravno. Kot lahko izpeljana, sintaktično funkcionalna in stilistično učinkovita možnost se je v knjižnem jeziku dokončno ustalil, le da je njegova frekvenca, s tem tudi razvrstitev, od pisatelja do pisatelja drugačna.", 347).

"Die stilistischen Nuancen" im Gebrauch der verbalen Partizipien auf $-\check{c}$ und -/aj/e in den literarischen Texten sind erst gegen Ende des 19. Jahrhunderts zu beobachten, als das ursprüngliche syntaktische System von Partizipialkonstruktionen bereits stark verändert war und die "Tendenzen einer Auflockerung" des festen morphologisch-syntaktischen Musters sich in einem "individuellen Eigenwillen" der Verfasser zeigten (vgl. M. Orožen, ebd., 348-353). 
In bezug auf die Gerundien auf -ši muß betont werden, daß unter 182 exzerpierten Belegen 61 Formen auf $-\varnothing /$-v sind. Diese finden sich bereits bei M. Ravnikar, am häufigsten kommen sie aber in Cafs Bearbeitung des Robinsons jun. vor (außerdem wurden sie auch von F. Levstik, J. Jurčič und J. Kersnik verwendet).

Ein Vergleich mit der religiösen Literatur im ostslowenischen Sprachraum läßt darauf schließen, daß die Gerundien auch in den literarischen Texten angenommen wurden (die Häufigkeit solcher Formen auf -ši in den literarischen Texten ist mit ihrer Häufigkeit in der religiösen Literatur vergleichbar - 2,6:2,72; dasselbe gilt auch für die Gerundien auf -č (die syntaktisch synonymen Formen auf -/aj/e in den literarischen Texten miteinbegriffen - 4,09:4,42).

Die Frequenz der Gerundien in den literarischen Texten sank - mit der ostslowenischen religiösen Literatur verglichen - nur um 6,44\% $(6,44: 7,15)$ - ein Beweis für die erfolgreichen Wiederbelebungsversuche dieses "pannonischen" morphologisch-syntaktischen Systems von Partizipien auch im Zentrum. Die meisten Verdienste an dieser konsequenten Übernahme der ostslowenischen partizipialen Ausdrucksweisen sind den Grammatikern zuzuschreiben. Die Gebrauchshäufigkeit dieser Formen in den Werken slowenischer Dichter, Schriftsteller und Übersetzer in der zweiten Hälfte des 19. Jahrhunderts wurde bereits von F. Metelko, vor allem aber von A. Janežič und F. Levstik beeinflußt, denn die Partizipien waren in den Grammatiken ausführlich dargestellt (morphologische Formen bei F. Levstik und syntaktische Klassifizierung bei A. Janežič). Die Grammatiker jener Zeit berücksichtigten morphologisch-syntaktische Eigenschaften des Altkirchenslawischen. Ihre entwicklungshistorischen und theoretischen Forschungserkenntnisse wurden von der begabtesten Generation der Verfasser bis zum Ende des 19. Jahrhundert befolgt. Die Gebrauchshäufigkeit der Formen auf -č und -ši und die literarischen Erfolge mancher Autoren standen in einem engen Zusammenhang miteinander; das gilt z. B. für die literarischen Programme der bekannten Literaturgesellschaft Mohorjeva družba bzw. diejenigen von Levstik und Šubič, für die Blütezeit der Epik mit den Mitarbeitern der literarischen Zeitschrift Vaje, für die vom Weltschmerz geprägten Werke von Erjavec und Stritar, für "eine seltsame Phantastik" bei Trdina, für einen "Realismus mit dem Schleier der Romantik" bei Kersnik und Tavčar, für zahlreiche Übersetzungen, veröffentlicht in den Zeitschriften Cvetje iz domačih in tujih logov, Slovanska knjižnica, Dramatično društvo..., ebenso aber auch für weniger erfolgreiche Epigonen, ${ }^{40}$ welche noch im Zeitalter des Naturalismus dem Sprachstil der erfolgreichsten Erzähler der zweiten Hälfte des 19. Jahrhunderts zu folgen versuchten. Thr literarisches Verstummen am Jahrhundertende bedeutete zugleich das Ende einer Epoche in der Sprachentwicklung, denn anstatt Partizipien zum Ausdruck syntaktischer Beziehungen wurde erneut eine periphrastische Syntax eingeführt. Diese diente als Ausgangspunkt für einen neuen sprachlichen Ausdruck bei Cankar und

40 Vgl. M. Kmecl: Od pridige do kriminalke, Ljubljana 1975. J. Pogačnik, F. Zadravec: Zgodovina slovenskega slovstva, Maribor 1973, 231-310. 
bei den Vertretern der Moderne. Das sprachlich Angemessene beruhte nicht mehr auf den archaischen Sprachmustern, sondern es berücksichtigte lediglich die neueren Erscheinungen, welche die slowenische Gegenwartssprache stark veränderten. Die Partizipial- und Gerundialkonstruktionen auf $-\check{c}$ und -ši, typische archaische syntaktische Mittel, die in den literarischen Texten des 19. Jahrhunderts noch ein Merkmal der sprachlichen Kultiviertheit waren, wurden zu sprachlichen Extremfällen, abgelehnt auch von der neuen Generation slowenischer (synchroner) Grammatiker und Sprachwissenschaftler (J. Sket, F. Levec, S. Škrabec, A. Breznik).

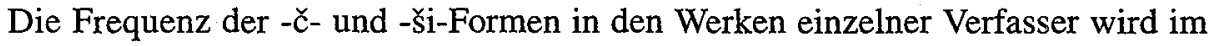
folgenden Kapitel näher dargestellt, und zwar in bezug auf die chronologische Einordnung der Texte. An dieser Stelle wird nur die Anzahl aller aus den literarischen Texten exzerpierten Partizipial- und Gerundialkonstruktionen sowie der Prozentsatz von -čund -ši-Formen aufgeführt.

Tabelle 6

\begin{tabular}{|c|c|c|c|c|c|}
\hline \multicolumn{6}{|c|}{ Literarische Texte } \\
\hline \multirow{2}{*}{$\begin{array}{l}\text { Anzahl der exz. Formen auf } \\
-\check{c}_{,},-s ̌ i,-/ a j / e\end{array}$} & \multicolumn{2}{|c|}{ Partizip } & \multicolumn{3}{|c|}{ Gerundium } \\
\hline & $-\breve{c}$ & $-\breve{c ̆ i}$ & $-\check{c}$ & $-\breve{s i}$ & $-/ a j / e$ \\
\hline 2021 & $27,36 \%$ & $1,33 \%$ & $24,93 \%$ & $\begin{array}{c}27,51 \% \\
18,85 \%\end{array}$ & \\
\hline
\end{tabular}

Der Anteil der -č- und -ši-Formen an der Gesamtzahl der aus den literarischen Texten stammenden Belege und der Belege aus der gesamten profanen Literatur ist beinahe gleich. Bei allen Formen auf -č und -ši ist ein leichter Rückgang zu beobachten (durchschnittlich 1,2\%), haupsächlich wegen der Zunahme der Formen auf -/aj/e in den literarischen Texten $(4,73 \% ; 18,85: 14,12)$. Die Verhältnisse im Vergleich zur zentralslowenischen religiösen Literatur veränderten sich demnach nicht; sie blieben denjenigen in der gesamten profanen Literatur gleich (am meisten vergrößerte sich der Anteil der Formen auf -ši; 27,51\%: 10,02\%). Die bisherigen Analysen weisen auf eine stark erhöhte Frequenz von Partizipial- und Gerundialkonstruktionen auf -č und -ši in den literarischen Texten des 19. Jahrhunderts hin. Im Vergleich zu ihrer Verwendung im 16., 17. und 18. Jahrhundert, ${ }^{41}$ ebenso aber auch in bezug auf ihre Frequenz in der zentralslowenischen religiösen Literatur dürfen wir in diesem Zusammenhang von Wiederbelebungsversuchen oder sogar von erfolgreicher Wiederbelebung des partizipialen morphologisch-syntaktischen Schemas in der slowenischen Schriftsprache des 19. Jahrhunderts reden (1815-1897; seit M. Ravnikar bis I. Cankar). Die Formen auf -č und -ši wurden - obwohl nicht usuell - von den slowenischen Grammatikern in der prekmurjischen Schriftsprache "entdeckt" und als angemessene morphologisch-syntaktische 
Lösungen empfohlen. Demzufolge blieben sie nicht nur auf den literatursprachlichen Gebrauch beschränkt, sondern sie verbreiteten sich auch in nichtliterarischen Texten. Allerdings konnten sie sich in der gesprochenen Sprache nie durchsetzen, denn die syntaktische Kondensation wurde in der mündlichen Rede vermieden. Anstelle von Partizipien wurden Nebensätze oder andere syntaktische kondensierende Strukturen verwen$\operatorname{det}^{42}$ (Partizip Passiv, auch Infinitiv); die vor allem in deutschsprachigen Gebieten geläufig waren und weniger archaisch wirkten als etwa die Gerundien auf -č und -ši. Die gesprochene Sprache unterschied sich eben deswegen stark vom geschriebenen Slowenischen, denn der Sprachgebrauch in den literarischen Texten war im 19. Jahrhundert von den grammatischen Normen und Vorschriften stark abhängig. Die Formen auf -č und -ši wurden künstlich wiederbelebt (F. Metelko machte zwar Ravnikars Gerundien geltend, jedoch mit vielen Korrekturen; F. Levstik normierte hingegen in seiner Grammatik die altkirchenslawischen Elemente ganz bewußt) und auf diese Weise den Verfassern angeboten. In den literarischen Texten wurden sie tatsächlich oft verwendet, sie wurden aber von den Adressaten als schriftsprachliche und künstliche syntaktische Mittel aufgefaßt und konnten daher im allgemeinen Sprachgebrauch nicht Fuß fassen. Die pannonische schriftsprachliche Tradition wurde durch die Grammatiker in der ersten Hälfte des 19. Jahrhunderts auch im Zentrum des slowenischsprachigen Gebietes bekannt (und literatursprachlich sogar fortgesetzt), jedoch auf den geschriebenen Sprachgebrauch beschränkt. Demzufolge ist das Fehlen der Formen auf -č und -ši in der alltäglichen Rede durchaus verständlich. Im Gegensatz dazu wurde die Wiederbelebung der einst verbreiteten Partizipial- und Gerundialkonstruktionen durch eine lockere Verbindung der Literatursprache mit der morphologisch-syntaktischen Struktur der prekmurjischen Schriftsprache und mit der Unterstützung der Grammatiker und Sprachwissenschaftler in der geschriebenen Sprache ermöglicht.

\subsubsection{Slowenische Belletristik}

Die Gebrauchshäufigkeit der Partizipial- und Gerundialkonstruktionen auf -č und -ši in der slowenischen Originalliteratur ist in Abhängigkeit von literarischen Gattungen und vom Sprachstil einzelner. Verfasser zu betrachten. Ebenso müssen dabei die Bemühungen um eine Individualisierung der slowenischen Sprache in der Mitte des 19. Jahrhunderts sowie die Wiederentdeckung ursprünglich slowenischer bzw. gesamtslawischer sprachlicher Ausdrucksmöglichkeiten berücksichtigt werden. All das war eng verbunden mit einer Suche nach der Nationalidentität bzw. mit dem kulturpolitischen Erwachen der Slowenen in Österreich-Ungarn. Die romantischen Bestrebungen um eine hohe (europäische) Literatur und der gewählte Ausdruck mit Hilfe der -č- und -ši-Formen waren noch nicht erwacht (jedenfalls nicht in der gehobenen Literatur, wel-

42 Über die unterschiedlichen Möglichkeiten syntaktischer kondensierender Strukturen vgl. die Abhandlung Funkce a vývoj syntaktických kondenzátorů v slovanských jazycich (M. Jelínek. In: Otázky slovanské syntaxe II, 1968, 389-395. 
che von M. Čop verlangt und von F. Prešeren verwirklicht wurde). Allerdings waren illyrische und panslawistische Ideen, angeregt durch die Ereignisse im Jahr 1848, für die Entdeckung ursprünglicher morphologisch-syntaktischer Gesetzmäßigkeiten der slowenischen Sprache und für die Wiederbelebung alter Lexik wie geschaffen. Der allgegenwärtige Sprachpurismus verdrängte sämtliche lexikalischen und syntaktischen Germanismen und verursachte dadurch eine starke Archaisierung und Slawisierung des Slowenischen; in diesem Zusammenhang wurden auch die Formen auf -č und -ši angeboten. Da die slowenischen Dichter und Schriftsteller in der Mitte des 19. Jahrhunderts zusätzlich Ideenträger des Slowenentums und auf dem kulturpolitischen Gebiet tätig waren, wurden die ursprünglich slowenischen (altkirchenslawischen) Partizipien zum Ausdruck von syntaktischen Beziehungen von ihnen ohne Einwand akzeptiert. Die Formen auf - $\breve{c}$ und -ši wurden dadurch zum Kennzeichen ihres literarischen Sprachausdrucks. In der einheimischen Literatur galten diese Formen als Merkmale eines gehobenen Stils und einer Intelektualisierung der Sprache. ${ }^{43}$ Sie waren auf die geschriebene Sprache beschränkt und verbreiteten sich besonders in der Epik, denn hier konnten ihre semantischen, stilistischen und syntaktischen Funktionen stärker zur Geltung kommen als etwa in der Lyrik und Dramatik. 64,15\% aller Partizipial- und Gerundialkonstruktionen auf -č (-/aj/e) und -ši im exzerpierten Sprachmaterial entstammen den epischen, $24,67 \%$ den lyrischen und $11,18 \%$ den dramatischen Texten. Allerdings wurden im Rahmen der Dramatik nur folgende Verfasser berücksichtigt: B. Tomšič (Lahkoverni, 1864), F. Levstik (Tugomer, 1876) und I. Cankar (Jakob Ruda, 1900); Levstiks Anteil erreicht dabei 77,64\% aller Belege. Die Durschnittsfrequenz der Formen auf -c (-/aj/e) und -ši beträgt 8,68 pro zehn Seiten epischer Texte (bei 1700 exzerpierten Textseiten), 6,84 pro zehn Seiten lyrischer Texte (bei 200 exzerpierten Textseiten) und 5,66 pro zehn Seiten dramatischer Texte (bei 150 exzerpierten Textseiten).

Die Partizipial- und Gerundialkonstruktionen auf -č und -ši kommen im 19. Jahrhundert am häufigsten bei J. Trdina vor, und zwar durchschnittlich 18,9mal pro zehn Textseiten (meist in Bajke). Über dem Durchschnitt liegt ihre Verwendung auch bei J. Jurčič $(16,07)$, I. Tavčar $(14,2)$, J. Kersnik $(10,6)$ und M. Pleteršnik $(9,9)$. Schwach vertreten waren sie dagegen bei J. Stritar $(4,9)$ und F. Erjavec $(3,8)$, überraschend wirkt aber auch ihr seltener Gebrauch in den bis 1871 veröffentlichten epischen Texten von $F$. Levstik (nur 5,2). ${ }^{44}$ Auch die Mitarbeiter der Zeitschrift Vaje bevorzugten die parti-

43 Bei M. Jelínek (Funkce a vývoj syntaktických kondenzátorů /.../, 393) wird die Gebrauchshäufigkeit syntaktischer kondensierender Strukturen (vor allem Gerundien) in Texten einem intensiveren Prozeß der sprachlichen Intelektualisierung zugeschrieben. Diese sei der höchste Grad der Gedankenordnung von kommunikativen Inhalten im Text. Dabei zitiert er die Definition der sprachlichen Intelektualisierung (Rationalisierung), denn es geht um "přizpůsobování jazyka $\mathbf{k}$ tomu, aby jeho jazykové projevy mohly být určité a presné, podle potřeby abstraktní a aby byly schopné vyjadřit souvislost a složitost myšleni, tedy zesilování intelektuální stránky řeči" (B. Havránek: Úkoly spisovného jazyka a jeho kultura. In: Studie o spisovném jazyce, Prag 1963, 38). Vgl. auch J. Toporišič: Enciklopedija slovenskega jezika, Ljubljana 1992, Stichwörter: izrazna sposobnost, miselna urejenost, racionaliziranost, sporočanje, upovedovanje. 
zipiale Ausdrucksweise nicht. Die meisten Partizipien treten bei J. Mencinger $(4,1)$ auf, der in seiner Humoreske Mešana gospoda (Ljubljanski zvon, 1881) die Gerundien auf -ši sogar mehrmals gebraucht als diejenigen auf -č $(63,4 \%: 36,6 \%)$. Es wurde angenommen, daß die naturwissenschaftlich orientierten Mitarbeiter von Vaje im reiferen Alter diese Formen als besonders lächerlich wirkende Stilmittel doch akzeptierten. Diese Annahme wurde jedoch von Mencinger selbst negiert, denn in seiner Satire Cmokavzar in Ušperna (Ljubljanski zvon, 1883) kommen auf dreißig Textseiten nur 12 partizipiale Formen auf -čc(-/aj/e) und -ši vor (4 Partizipien auf $-\check{c}, 4$ Gerundien auf -č, 2 Gerundien auf -ši und 2 auf -/aj/e). Eine starke Verminderung der ši-Formen ist auch bei F. Detela und A. Funtek zu beobachten, während A. Koder und F. Govekar ihre durchschnittliche Frequenz fast erreichen. Äußerst selten treten Gerundien bei R. Murnik, Z. Kvedrova, F. S. Finžgar und F. Ks. Meško auf, lediglich die Formen auf -č sind im Korpus belegt. Dasselbe gilt für I. Cankar, jedoch steigt bei ihm die Anzahl der Gerundien und vor allem departizipialer Adverbien auf -/aj/e. Die Partizipien auf -č und -ši wurden allerdings auch schon in der Mitte des 19. Jahrhunderts vermieden, obwohl es sich eher um Schriftsteller mit geringem Einfluß handelte. P. Hicinger z. B., der seine Schriften in Novice veröffentlichte, verwendete in seiner kurzen historischen Erzählung Močni baron Ravbar (Ljubljana 1858) nur eine partizipiale Form auf -aje, die Partizipialkon-

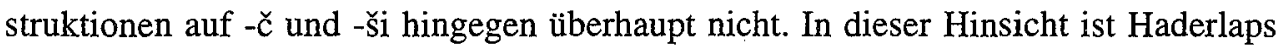
Briefsammlung mit dem Titel Zbirka ljubimskih in ženitovanjskih pisem (Ljubljana 1882) zu erwähnen: Die stilistisch markierte partizipiale Ausdrucksweise wird lediglich in festen Wendungen erhalten, ${ }^{45}$ sonst treten die Partizipien in den Texten stark in den Hintergrund. Bei den führenden slowenischen Autoren in der zweiten Hälfte des 19. Jahr-

44 In der Erzählung Martin Krpan (Slovenski glasnik, 1858) kommt das Gerundium auf -ši nur einmal vor (SG 1958, Nr. 1, S. 2), ebenso selten werden aber auch die Partizipialkonstruktionen auf -č und -/aj/e gebraucht (13mal, und zwar im publizierten Text sowie in der Manuskriptvariante im Band IV der gesammelten Werke (Zbrano delo). Die Gerundien sind in Levstiks epischen Schriften bis 1871 äußerst selten zu finden, und es stellt sich die Frage, warum er sie nicht verwendete. Es scheint, daß er sich ihrer "Unbelebtheit" bewußt war und daß er sich dem "einzig möglichen Leser", d.h. dem Bauer und einfachem Volk sprachlich anpaßte. Nach dieser Logik, veröffentlicht in Popotovanje od Litije do Čateža (1858) wäre für die slowenische literarische Tätigkeit nur die Sprache des Volkes

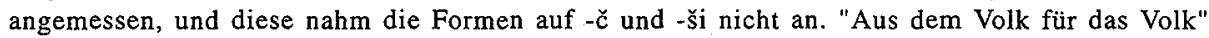
schreiben hieß es bei Levstik; das bedeutete zugleich aber auch die Negierung einiger seiner späteren sprachlichen Prinzipien, und zwar derjenigen, die eine Annäherung der slowenischen Schriftsprache an das Altkirchenslawische voraussetzten. Seinem literarischen Programm in Popotovanje entsprechend schrieb er in einer lebendigen Volkssprache. In den 70er Jahren hingegen kam er zu der Erkentnis, daß die Ansicht über den "maßgeblichen Landsmann" in der Epik nicht mehr genügt; seitdem verwendet er eine den einfachen Leuten angepaßte Sprache in seinen Schriften nicht mehr. Vgl. M. Orožen, Levstikovi pogledi na jezik; ebenso M. Kmecl, Od pridige do kriminalke, 133-138. Interessanterweise erscheint in Doktor Bežanc (Zvon, 1870) die Form auf -v (opertiv; Blatt 21, S. 330), welche bei anderen Autoren sonst selten vorkommt.

ZAHVALIVS̆I se Vam za veliko zaupanje, ki ga v mene stavite, moram Vam vendar sporočiti, da nisem namenjena, Vaši želji ustreči. (47) Vso srečo Vam ŽELEC̆A, upam, da me dalje ne boste nadlegovali s takimi pisarijami. (44). 
hunderts sind solche Tendenzen nicht zu konstatieren. Es soll an dieser Stelle der Text Rokovnjači (Ljubljanski zvon, 1881) erwähnt werden. J. Jurčič begann diesen Roman zu schreiben, jedoch starb er während der Arbeit. F. Levec, Redakteur von Ljubljanski zvon, überredete J. Kersnik, den Text zu vollenden. ${ }^{46}$ Die sprachliche Struktur wurde dabei nicht geändert, ${ }^{47}$ was den hohen Grad der sprachlichen Kultiviertheit bei den erfolgreichsten Vertretern des slowenischen Realismus bestätigte. Diese zeigt sich in souveräner Beherrschung orthographischer, morphologischer und syntaktischer Normen der slowenischen Schriftsprache. Die -č- und -ši-Formen verwenden beide Autoren beinahe gleich; einige Abweichungen gibt es in der Frequenz (Jurčičs Anteil am Text beträgt 39,2\%, und sein Anteil an Partizipialkonstruktionen auf -č und -ši 51,4\%) und im Gebrauch verschiedener Formen (Kersnik verwendet öfter die Form auf -/aj/e und außerdem sind bei ihm auch Gerundien auf $-\varnothing /-\mathrm{v}$ zu finden). Die Unterschiede sind als autorenspezifische stilistische Besonderheiten interpretierbar. Impressionistische und lyrische Elemente ("impresionistično občuteni pokrajinski opisi in lirske kadence na koncu odstavkov") ${ }^{48}$ bei Kersnik reduzierten die Frequenz von - ̌̌- und -ši-Formen ein wenig, gleichzeitig begünstigten sie aber den Gebrauch von Partizipien auf -/aj/e. Bei J. Kersnik kann jedoch von einem Rückgang der Partizipialverwendung noch nicht die Rede sein, obwohl sein "Impressionismus" bereits eine neue Ausdrucksweise ankündigte. Völlig akzeptiert wurde diese erst am Ende der 90er Jahre mit I. Cankar, als die Formen auf -ši nicht mehr gebraucht wurden.

Im Bereich der lyrischen Texte treten die Partizipialkonstruktionen am häufigsten bei J. Vesel Koseski auf. Überraschend viele Gerundien auf -ši und ungewöhnliche Beziehungen im Gebrauch von -č- und -ši-Formen sind für ihn charakteristisch. Sogar 45,6\% aller Partizipialkonstruktionen auf $-\check{c}(-/ a j / e)$ und -ši werden von den Formen auf -ši gestellt. Besonders interessant ist dabei der hohe Anteil an Gerundien auf -ši einerseits $(41,9 \%)$ und der niedrige Anteil an Gerundien auf -č andererseits $(6,2 \%)$, denn solche Proportionen sind sonst nicht zu beobachten. ${ }^{49}$ Weiters sind Gerundien auf -/aj/e mit $8,7 \%$, Partizipien auf -č mit 39,5\% und solche auf -ši mit 3,7\% vertreten. Die Durchschnittshäufigkeit dieser Formen pro zehn Textseiten beträgt bei Koseski 27,9; sie

In der Bemerkung zum bereits von Kersnik verfaßten 12. Kapitel wendet sich F. Levec an die Leser von Ljubljanski zvon mit folgenden Worten: "Pokojni Jurčič tega romana ni dovršil, a v njegovi literarnej ostalini našli smo več sto skrbno spravljenih drobnih listkov /.../. Na podlagi te osnove bode Rokovnjače nadaljeval Janko Kersnik na Brdu /.../, ki je bil pokojnemu Jurčiču najboljši prijatelj. Tudi se je /Jurčič/ malo dni pred smrtjo s svojim prijateljem pogovarjal, ako misli roman nadaljevati /.../." J. Jurčič verfaßte 73, und J. Kersnik 113 Seiten dieses Romans.

47 J. Kersnik setzte den Roman erfolgreich fort, "tako da površen bralec niti ne opazi, kdaj preneha prvi in kdaj začne pripovedovati drugi pripovedovalec." Vgl. Zgodovina slovenskega slovstva III, Ljubljana 1967 (A. Slodnjak, Realizem), 127.

Ebd., 130.

Bei S̆. Küzmič stellen die Gerundien auf -ši $19,4 \% \%$, bei M. Ravnikar $39,7 \% \%$ und bei J. Trdina $48,4 \% \%$ aller Belege dar. 


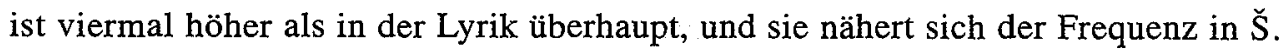
Küzmičs Nouvi zakon $(37,1)$ an. Über den Durchschnitt liegt die Häufigkeit der Partizipien auch bei M. Valjavec $(8,28)$; allerdings überwiegen die Gerundien auf -/aj/e mit $27,5 \%$, während die Formen auf -ši mit $20,6 \%$ aller Partizipialkonstruktionen vertreten sind. Es sind weiterhin 41,3\% Partizipien auf -č und 10,6\% Gerundien auf -č festzustellen. F. Haderlap, der in den epischen Texten klischeehafte Formen auf -ši zwar verwendete, vermied diese in seiner Lyrik völlig. Ebenso selten sind sie in den Werken von L. Volkmer, M. Vilhar, G. Krek, I. Hribar und A. Aškerc zu finden, überhaupt keine Partizipialkonstruktionen auf -ši gibt es bei A. Funtek, S. Gregorčič und I. Cankar. Bei allen erwähnten Verfassern läßt sich demnach ein beträchtlicher Rückgang im Gebrauch von Partizipien feststellen. Deshalb liegt die Durchschnittsfrequenz der Formen auf -č und -ši niedriger als diejenige in der Poesie.

In der Dramatik zeigt sich die partizipiale Ausdrucksweise vor allem bei Levstik; der Anteil an ši-Formen liegt bei 31,8\% (einschließlich der Formen auf $-\varnothing /-v$ ), die gerundialen -č-Formen sind mit 27,2\% vertreten, ebenso die Partizipien auf -č, und der Anteil an Formen auf -/aj/e beträgt nur 13,8\% aller Belege. Die Durchschnittshäufigkeit pro zehn Textseiten erreicht den Wert 9,4, und bei I. Cankar, der keine gerundialen -šiFormen verwendete, beträgt sie nur 1,2 (meist die Partizipien auf -ši). Bei B. Tomšič liegt die Frequenz der Partizipialkonstruktionen zwar niedriger als etwa bei F. Levstik $(3,5)$, jedoch ist der Anteil der -ši-Formen hoch (35,7).

\subsection{2 Übersetzungen}

Der Gebrauch von Partizipial- und Gerundialkonstruktionen in der slowenischen Schriftsprache des 19. Jahrhunderts wurde wesentlich auch durch die Fremdsprachen beeinflußt. Die Grammatiker empfahlen die Formen auf -č und -ši als vorbildliche gesamtslawische syntaktische Mittel; demzufolge wurden sie aus dem Serbokroatischen, Russischen und Tschechischen reichlich übernommen. Außerdem waren sie im Slowenischen stilistisch markiert (schriftsprachlich); das gilt vor allem für die Partizipien auf -ši, denn sie setzten sich in der gesprochenen Sprache nicht durch, obwohl sie aufgrund ihren "Slawentums" modisch geworden waren. Ihre Gebrausfrequenz in den Übersetzungen war durch die jeweilige Originalsprache bedingt, allerdings waren die slowenischen Übersetzer diesbezüglich nicht eingeschränkt; einige vermehrten sogar ihre Häufigkeit im Gebrauch (so z. B. J. Vesel Koseski, O. Caf, F. Cegnar, F. Levstik). Koseski verletzte dabei einige grundlegende Gesetzmäßigkeiten der partizipialen Ausdrucksweise, wie etwa das Prinzip, nach dem das Subjekt in der Partizipialkonstruktion mit dem Subjekt im Hauptsatz identisch sein soll, oder das Prinzip, nach dem in partizipialen Syntagmen lediglich sekundäre Handlungen ohne zusätzliche konnotative $\mathrm{Nu}$ ancen ausgedrückt werden sollen. Weiter berücksichtigte er nicht die Tatsache, daß die Adverbialisierung von Gerundien begrenzt war (zumindest zur Zeit der Bemühungen um ihre Wiederbelebung). Auch die Regeln einer aspektorientierten Ableitung von Par- 
tizipien bzw. die Beschränktheit der Gerundien auf -č auf die Gleichzeitigkeit und der Gerundien auf -ši auf die Vorzeitigkeit akzeptierte er nicht. Schließlich beachtete er nicht die Erkenntnis, daß der prädikative Gebrauch von Partizipien nicht "im Geiste" 50 der slowenischen Sprache war. Jedenfalls waren die Übersetzer in den Bestrebungen für eine Wiederbelebung der Formen auf -č und -ši in der slowenischen Schriftsprache am erfolgreichsten. Im Rahmen literarischer Texte waren dafür gerade die Übersetzungen bestens geeignet, da die betreffenden Formen in den benachbarten slawischen Sprachen lebendig waren; den ostlowenischen Übersetzern waren sie außerdem bereits von der prekmurjischen Schriftsprache bekannt. All das schaffte die Möglichkeit, die alten Formen auf eine natürlichere und unmittelbarere Weise wiederzubeleben. Gerade die Übersetzungen in den 50er Jahren (O. Caf) waren dabei entscheidend, daß die auf den ersten Blick toten Formen " sich auch im Neuslowenischen durchsetzten" und zugleich in der belletristischen Sprachform angenommen wurden. Der Gebrauch von -č- und -šiFormen in der slowenischen Literatur erreichte seinen ersten Höhepunkt in Cafs Übersetzung von Robinson jun.; eine solche Frequenz der partizipialen Formen ist später nur noch in Levstiks Übersetzungen übertroffen worden. Jedoch soll betont werden, daß Levstik die morphologisch-syntaktischen Gesetzmäßigkeiten des Altkirchenslawischen bewußt nachahmte und daß sein häufiger Partizipialgebrauch die Folge einer gründlichen Erforschung der ältesten slawischen Sprachdenkmäler ist. In der dritten Epoche seiner schöpferischen Tätigkeit ${ }^{51}$ plädierte er für eine Archaisierung, welche aber von seinen Zeitgenossen nicht akzeptiert wurde und bestärkte die Gegner der -č- und -ši-Formen in ihren Bemühungen sogar. Zur Jahrhundertwende erfolgte noch ein Versuch der Befürworter slawischer morphologisch-syntaktischer Modelle, um das Interesse an den Partizipien auf -č und -ši zu erwecken: Diese wurden nämlich in zahlreichen Übersetzungen aus den slawischen Sprachen intensiv verwendet. A. Gabršček, Redakteur der Sammlung Slovanska knjižnica, veröffentlichte von 1893 bis 189993 Bände der übersetzten Texte mit einer reichhaltigen Struktur an Partizipialkonstruktionen. Allerdings konnten die -č- und -ši-Formen nicht mehr ins Leben gerufen werden. Vierzig Jahre nach Cafs erfolgreicher Einführung der Partizipien in die slowenische Schriftsprache konnten die Versuche, mit Hilfe von Übersetzungen aus den

50 M. Jesenšek: Skladenjski sistem /.../, (Magisterarbeit), Ljubljana 1989, 141-142. Zu den begrenzten Möglichkeiten in der Verwendung von Partizipialkonstruktionen beim Übersetzen vgl. E. Dvořak, Přechodníkové konstrukce $\mathrm{v}$ překladech beletrie do čestiny. In: Acta universitatis Caroline (Philologia 2-4), Slavica Pragensia XIV, Prag 1972, 101-114. Die Problematik der slowenischen Übersetzungen aus dem Tschechischen und Russischen ähnelt der Problematik der Übersetzungen aus dem Russschen ins Tschechische. Die aktivische Diktion des Originals hat dabei einen besonders starken Einfluß auf die Gebrauchshäufigkeit der -č- und -ši-Formen. Meistens erscheinen die übernommenen partizipialen syntaktischen Konstruktionen in übersetzten Erzählungen, seltener in Schilderungstexten und Dialogen. Die höchste Frequenz ist festzustellen, "kde ve zkoumaném textu výrazně převládají motivy dynamické", niedriger ist sie, "kde epická linie je kombinována s četnými popisy $/ . . . /$ a úvahami /.../." (106). 
slawischen Sprachen diese Formen wiederzubeleben, nicht mehr gelingen. Die slowenische Schriftsprache war zu dieser Zeit einer intensiven Entwicklung ausgesetzt. Die archaisch wirkenden und in lexikalischer und/oder syntaktischer Hinsicht stark slawisierten Übersetzungen befolgten normativ bereits fragliche Nachdrucke der Grammatik von Janežič. Dementsprechend konnten sie den Leser von der Angemessenheit der Gerundien auf -č und (besonders) auf -ši in der slowenischen Schriftsprache nicht überzeugen. Nachdem die erste Welle der panslawistischen Bestrebungen nachgelassen hatte, wurden sie uninteressant, unlebendig und aus der slowenischen Schriftsprache wiederum fast völlig vebannt. Der häufige Gebrauch in den Übersetzungen am Ende des 19. Jahrhunderts war der letzte und erfolglose Versuch, sie in der slowenischen Sprache zu festigen. Sie waren zwar slowenische Ausdrucksweisen und in den benachbarten slawischen Sprachen auch lebendig, jedoch "einen alten Hut" möchte (nach S. Škrabec) keiner mehr tragen. Als "richtig" orientiert galten am Jahrhundertwende diejenigen slowenischen Übersetzer, welche Ravnikars "Satzkürzug" nicht befolgten, z. B. J. Zalokar, J. Burger, A. Lah; diese haben die Werke von K. Schmid und T. Kempčan ins Slowenische übersetzt. Der Anteil der -č- und -ši-Formen am gesamten Wortmaterial beträgt bei ihnen nur 6,5\%, durchschnittlich erscheinen die Partizipien 5,45mal pro zehn Textseiten. Interessanterweise überwiegen Partizipien auf $-\check{c}(63,3 \%)$; unter den Gerundien liegt der Prozentsatz der -č-Formen bei 26;6\% (vorwiegend das klischeehafte rekoč); $10,1 \%$ der Belege sind die Formen auf -/aj/e, während die Partizipialkonstruktionen auf -ši nicht vorkommen; allerdings übernimmt der Infinitiv oft die Rolle eines syntaktischen Kondensators. Insgesamt wurden 1437 Belege aus der slowenischen Übersetzungsliteratur des 19. Jahrhundert ausgewertet. Die Durchschnittsfrequenz der Formen auf -č(-/aj/e) und -ši pro zehn Seiten beträgt 13,06 (bei 1100 exzerpierten Textseiten), und liegt, verglichen mit der slowenischen Originalliteratur, demnach anteilsmäßig wesentlich höher. Das zahlenmäßige Verhältnis zwischen den Gerundien auf -č und -ši ist annähernd gleich (1 : 1,17). 46,97 der Belege sind Formen auf -č $(17,95 \%$ Partizipien und 29,05\% Gerundien), 35,07\% Formen auf -ši (1,04\% Partizipien und $34,03 \%$ Gerundien - 4\% davon sind die Formen auf $-\varnothing /-\mathrm{v}$ und $30,03 \%$ auf -ši) und 17,96\% Formen auf -/aj/e. Die meisten Beispiele entstammen der Epik $(85,12 \%)$; es folgen lyrische Texte mit 7,87\% und dramatische Texte mit 7,01\% der Belege, in denen der Anteil der -č- und -ši-Formen (ausgenommen J. Vesel Koseski) äußerst niedrig war.

F. Levstik war derjenige unter den slowenischen Übersetzern, der die Formen auf -č und -ši am häufigsten vewendete, im Durchschnitt 49,8mal pro zehn Seiten. Eine sol-

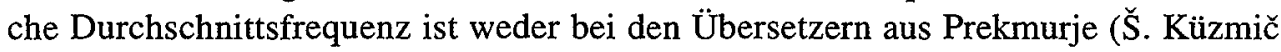
37,1, M. Küzmič 37,3) noch bei J. Vesel Koseski $(27,9)$ zu finden - ein Beweis dafür, daß Levstik das altkirchenslawische System von Partizipialkonstruktionen in die slowenische Schriftsprache gekonnt übertragen hat. ${ }^{52}$ Das Verhältnis zwischen den Gerundien auf -č und -ši beträgt $1: 1,15$, das Verhältnis zwischen den Partizipien und 
Gerundien hingegen $1: 6,47$. Auf 105 Textseiten treten 523 Partizipialkonstruktionen auf, $13,39 \%$ davon sind Partizipien (11,67\% auf $-\check{c}, 1,72 \%$ auf $-s ̌ i), 86,61 \%$ hingegen Gerundien (42,83\% auf -č, 37,09\% auf -ši und 6,12\% auf-/aj/e). Mit der Kultiviertheit der slowenischen Sprache im Rahmen des Panslawismus bzw. des Altkirchenslawischen beschäftigte sich bereits $O$. Caf. ${ }^{53}$ Aus dem Tschechischen übersetzte er den Robinson junior (Robinson Mlajši), wobei er die Formen auf -č(-/aj/e) und -ši oft gebrauchte $(10,08)$. In bezug auf die Frequenz der č- und ši-Formen ist die Übersetzung mit Levstiks Schriften zu vergleichen (das Verhältnis zwischen den Partizipien und Gerundien beträgt $1: 4,9$ ); allerdings erscheinen bei Caf viel öfter die Formen auf $-\varnothing /$-v (15,49\% im Rahmen der gesamten Partizipialstruktur). Die meisten slowenischen Verfasser gebrauchten sie nämlich gar nicht oder nur selten (z. B. M. Majar, F. Levstik, J. Jurčič, J. Kersnik). Der hohe Prozentsatz der Formen auf -/aj/e $(28,45 \%)$ weist auf den Einfluß des Tschechischen hin, denn höher liegt er nur noch bei Pleteršniks Übersetzung des russischen Epos Slovo o polku Igorjeve $(56,66 \%)$. Bei F. Cegnar (Übersetzung der Babica von B. Němcova) kommen je zehn Seiten durchschnittlich 6,73 Partizipialformen auf -č(-/aj/e) und -ši vor; es überwiegen die Gerundien auf -ši (37,13\%, d.h. $1,36 \%$ mehr als bei Caf), das tschechische Original beeinflußte aber auch die Frequenz der Formen auf -/aj/e (24,75\%). Die Partizipial- und Gerundialkonstruktionen sind reichlich auch in den Übersetzungen zu finden, welche in der Sammlung Slovanska knjižnica publiziert wurden $(9,44)$, ebenso aber auch bei J. Leban, der noch 1898 in einer Übersetzung aus dem deutschen Original durchschnittlich 6,8 Formen auf -̌̌(-/aj/e) und -ši pro zehn Textseiten gebrauchte; darunter sind 42,85\% Gerundien auf -ši. F. Haderlap gelang es dagegen, auch bei der Übersetzungsarbeit seinen eigenen Stil zu bewahren: In seiner Übersetzung von Tausend und einer Nacht (Tisoč in ena noč) gab er die Gerundien auf -ši fast völlig auf (nur 2\%), und auch die Formen auf -č und -/aj/e verwendete er äußerst selten $(1,58)$.

Im Bereich der lyrischen Übersetzungen ist J. Vesel Koseski ein Sonderfall, jedoch ist die hohe Frequenz der gebrauchten Partizipialkonstruktionen auf -č und -ši eher die Folge seiner besonderen Diktion und seiner ziemlich freien Übersetzung (fast Bearbeitung) von Byrons Mazepa. ${ }^{54}$ Die Durchschnittshäufigkeit pro zehn Seiten beträgt 23,8; es gibt 32\% Gerundien auf -ši, nur 5\% solcher auf -č und 19\% auf -/aj/e. Die Partizipien und Gerundien stehen in einem Verhältnis von $1: 2,25$; die Partizipien auf -č sind mit

53 Es ist interessant, daß Levstik in seiner Schrift Popotovanje von Cafs Slawisierung noch nicht begeistert war. Dieser bemühte sich darum, die lexikalisch und syntaktisch vom Tschechischen beeinflußte ostslowenische Sprachvariante der Schriftsprache im Zentrum anzupassen; dabei berücksichtigte er auch die Gesetzmäßigkeiten des Altkirchenslawischen. Durch Caf wurde - bereits vor Levstiks Zeiten - in der slowenischen Syntax ein System von Partizipialkonstruktionen angeboten, welches sowie im Tschechischen als auch in der pannonischen literarischen Tätigkeit bestätigt war. Vgl. M. Orožen, Levstikovi pogledi na jezik, 59. imena slobodno pel in pomnožil Jovan Koseski. Ljubljana 1868. 
$38 \%$ und die Gerundien auf -ši mit 6\% vertreten. Ein Vergleich mit seiner Originallyrik zeigt jedoch, daß die Übersetzungsvorlage keinen wesentlichen Einfluß auf die Frequenz der Partizipien ausübte $(27,9: 23,8)$; in der Übersetzung ist sie lediglich um $14,6 \%$ niedriger, und die unterschiedlichen Partizipialformen werden beinahe verhältnisgleich verwendet. In der Übersetzung ist lediglich eine Zunahme im Gebrauch der Formen auf -/aj/e festzustellen; zugleich verminderte sich der Anteil Gerundien auf -ši $(41,9 \%: 32 \%)$ einerseits und andererseits erhöhte sich der Anteil der Partizipien auf -ši $(3,7 \%: 6 \%)$. Bei J. Žemlja läßt sich (im Vergleich zu Koseski) eine wesentlich reduzierte Gebrauchshäufigkeit beobachten $(9,09)$, es überwiegen aber die Partizipien $(63,6 \%)$ und Gerundien auf -č $(27,2 \%)$.

In der Dramatik beträgt die Durchschnittsfrequenz der Partizipial- und Gerundialkonstruktionen 4,28; die Gerundien auf -č, -ši und -/aj/e sind etwa gleich stark vertreten $(31,4 \%: 28,5 \%: 40,1 \%)$, und das Verhältnis zwischen den Partizipien und Gerundien liegt bei $1: 10,4$. Interessant ist Vilhars Übersetzung der deutschen Komödie To sem bil jaz!. Die Partizipialformen kommen hier äußerst selten vor $(3,3)$, es findet sich aber ein Gerundium auf -ši (klischeehaftes rekši), obwohl diese Form in der Originallyrik von M. Vilhar nicht zu finden ist.

\subsection{Nichtliterarische Texte}

Die erfolgreiche Wiederbelebung der Formen auf -č und -ši in der Literatur aus der Mitte des 19. Jahrhunderts hatte eine bestimmende Wirkung auch auf ihre Frequenz in nichtliterarischen Texten. Zuerst fanden sie in Lehrbüchern Gebrauch, und zwar in den Lesebüchern für Gymnasien, welche nach den Richtlinien des Entwurfs für die Organisation der Gymnasien und Realschulen in Österreich (Osnutek organizacije gimnazij in realk v Avstriji) ${ }^{55}$ von J. Bleiweis und F. Miklošič herausgegeben wurden. Da den Schülern die besten einheimischen literarischen Werke vorgestellt werden sollten, gewann auch die slowenische Schriftsprache an Bedeutung, denn die slowenische Originalliteratur in der ersten Hälfte des 19. Jahrhunderts war sprachlich nicht homogen. Es gab zahlreiche regionale Varianten, und trotz zweier normierter slowenischer Schriftsprachen wurden die schriftsprachlichen Vorschriften nicht beachtet. Demnach war es notwendig, die schriftsprachliche Norm zu vereinheitlichen. "Offiziell" geschah das mit der Einführung einer einheitlichen Schriftsprache beim Unterricht an den slowenischen Gymnasien. Hauptsächlich war das der Verdienst von F. Miklošič: Bei der Reorganisation des slowenischen Schulwesens bemühte er sich um die Einführung der sloweni-

Der Entwurf wurde 1849 vom Bildungsministerium herausgegeben, denn Mittel- und Hochschulen wurden nach der Revolution 1848 durch mehrere Reformen verändert. Das Grundschulsystem dagegen wurde erst 1869 gesetzlich geregelt, und das bedeutet zugleich die Einführung der allgemeinen Schulpflicht auf dem slowenischsprachigen Gebiet (vgl. A. Vovko, Cerkev in slovensko šolstvo v 19. stoletju. In: Vloga cerkve v slovenskem kulturnem razvoju 19. stoletja. Ljubljana 1989, 61-69. 
schen Unterrichtssprache; nach seinem Vorschlag sollte außerdem der Sprachgebrauch in der Übersetzung von Državni zakonik für den Slowenischunterricht vorbildhaft sein. ${ }^{56}$ Die von Klemann bzw. Bleiweis herausgegebenen Lesebücher ${ }^{57}$ sollten trotz ihrer sprachlichen Verschiedenheit als ofizielle Lehrbücher für die 1., 2., 3. und 4. Gymnasialklasse dienen, während die Lesebücher für höhere Gymnasialklassen er selbst (mit Hilfe von Navratil) verfaßt hatte. Durch die Ausschnitte aus den slowenischen literarischen Texten lernten die Gymnasiasten die partizipiale Ausdrucksweise kennen. Da sie diese Formen in der gesprochenen Sprache nicht beherrschten, akzeptierten sie sie als typische "neuslowenische" schriftsprachliche Elemente. Die partizipialen Formen konnten sich unter den einfachen Leuten im Gebrauch nicht festigen, da die Grundschulpflicht erst allmählich eingeführt wurde und da die Sonntagsschulen hauptsächlich zum Erlernen des Lesens und Schreibens geeignet waren, einen anspruchsvolleren Sprachunterricht jedoch nicht anbieten konnten. ${ }^{58}$ Es ist außerdem bekannt, daß auch spätere Grundschulgrammatiken lediglich elementares Sprachwissen vermittelten und demnach das Problem der Partizipial- und Gerundialkonstruktionen nicht behandelten. Slomšeks Lehrbuch Blaže in Nežica v nedeljski šoli war an den Sprachunterricht in den unteren Schulklassen sprachlich dermaßen angepaßt, daß die (unter dem Volk auch unbekannten) Gerundien auf -ši nur ausnahmsweise vorkamen. Sprachlich gebildete Menschen (in der zweiten Hälfte des 19. Jahrhunderts vermutlich mit absolvierter mittlerer Reife) erlernten die Formen auf -č und -ši in der Schule, während sprachlich Ungebildete sie als ungewöhnlich und ungeschickt empfanden; demzufolge konnten sich diese in der gesprochenen Sprache nicht festigen. Die Partizipial- und Gerundialformen wurden also bereits in der Schule auf die geschriebene Sprache beschränkt; außerdem trennten sie gebildete und weniger geschulte Sprachbenutzer voneinander. Alle Versuche der Wiederbelebung von - ̌c- und -ši-Formen waren auf diese Weise schon von Anfang an stigmatisiert, denn sie mußten erst gelernt werden, entweder beim Schulunterricht oder durch das Lesen literarischer und sonstiger Texte. Der literarische Sprachgebrauch förderte das Erlernen dieser Formen wesentlich, so daß sie auch in nichtliterarischen Texten schnell ihren Platz fanden - zunächst in populärwissenschaftlichen und wissenschaftlichen Schriften, in den 70er und 80er Jahren aber auch in der slowenischen Publizistik; schließlich wurden sie auch in den Sachtexten allgemein verwendet. Eben ihr häufiger und oft auch unkorrekter und stilistisch unangemessener Gebrauch in der Amtssprache (z. B. A. Levec, Zbirka obrazcev za slovensko uradovanje po sodiščih, Ljubljana 1889) trugen wesentlich dazu bei, daß die partizipiale Ausdrucksweise ab-

57 J. Klemann, Ljubljanaer Gymnasialleiter, veröffentlichte ein Lesebuch für die 1. Klasse; nach seiner dienstlichen Versetzung wurde die Arbeit von J. Bleiweis fortgesetzt (vgl. J. Ciperle, Gimnazije na Slovenskem v letu 1848 in njihov razvoj do leta 1918. In: Slovenski šolski muzej, Ljubljana 1979).

"V praksi so omenjene šole /nedeljske/ pogosto pomenile zasilne začetne osnovne šole, ker rednih ni bilo dovolj, oziroma jih otroci zaradi zaposlenosti med tednom niso mogli obiskovati." (A. Vovk, ebd., 62). 
gelehnt wurde. Die richtige Reihenfolge verschiedener Textteile sowie ihre Abhängigkeit voneinander wurden in langen, schwer übersichtlichen Sätzen eben wegen den falsch gebrauchten Partizipial- und Gerundialkonstruktionen stark beeinträchtigt. Obwohl in den literarischen Texten positiv bewertet, bekamen diese Formen in der Amtssprache allmählich ein negatives Vorzeichen, denn besonders die Partizipialkonstruktionen auf -ši wurden zum Synonym für die unverständliche "amtliche" Diktion. Demnach wurden sie in zunehmendem Maße als überlebte, in der gesprochenen Sprache fremde und nicht usuelle syntaktische Elemente empfunden.

\subsubsection{Alltagssprachliche Texte}

Unter den verschiedenartigen der alltäglichen Kommunikation dienenden Textformen wurden zur Untersuchung nur Einladungen, Anzeigen und Mitteilungen herangezogen. Im 19. Jahrhundert waren sie in den Zeitungen und Zeitschriften allerdings noch selten zu finden. Als besondere Textklassen bildeten sie sich erst allmählich heraus, und so erschienen Kleinanzeigen in den meisten Zeitungen (mit der Ausnahme von Slovenski narod) noch in recht kleiner Zahl. Die neue Art des Kommuniezierens, beeinflußt von der Entwicklung in der Wirtschaft und Technik, von wachsendem Handel und reichhaltigen Angeboten im Kapitalismus, ebenso aber auch von der zunehmend "verbraucherorientierten" slowenischen Bürgerschaft übernahm das schriftsprachlich normierte syntaktische System von Partizipial- und Gerundialkonstruktionen nicht. Die Zeitung Slovenski narod veröffentlichte im Jahr 1895 keine einzige Kleinanzeige, in der die Partizipialkonstruktionen auf -ši gebraucht worden wären. In verbraucherorientierten Werbungstexten wurden die Formen auf -ši bewußt vermieden, da sie in der alltäglichen Kommunikation nicht usuell und angemessen waren. Wenn das nicht der Fall gewesen wäre, hätte man sie in der Werbungssprache syntaktisch und stilistisch sicher entsprechend ausnutzen können. Selten gebraucht wurden auch die Gerundien auf -̌̌ $(16,4 \%)$; meist erscheinen sie in klischeehaften Höflichkeitsfloskeln. Die gerundialen Formen auf -/aj/e waren noch seltener zu finden (7,8\%). Unter den Partizipien auf $-\check{c}$ überwiegt der attributive Gebrauch (meist erscheinen sie als vorangestellte Attribute, nachgestellt werden sie dagegen selten verwendet). Ebenso selten sind prädikativ gebrauchte Partizipien, während die substantivierten Formen häufiger vorkommen. Keine ši- und äußerst seltene verbale č-Formen in Kleinanzeigen bestätigten die Annahme, daß diese Formen als überlebt und sprachlich marginal galten. Interessanterweise geschah das aber in der Zeitung, die sich um die sprachliche Archaisierung sonst sehr bemuihte ${ }^{59}$ und die Partizipialkonstruktionen auf -č und -ši auch oft verwendete. Es

Vgl. A. Breznik: O časnikarski slovenščini. In: Jezikoslovne razprave (hrsg. von J. Toporišič), Ljubljana 1982, 133-161. In der Abhandlung wird hervorgehoben, daß die Zeitung Slovenski narod zwischen 1892 und 1918 eine "reale Sprache"verwendete, besonders unter Redaktion von D. Majaron und I. Tavčar. "Sprachexperimente"- sie zeigten sich in der "Benachteiligung" der slowenischen Sprache durch Jurčičs Sprachmischung, Levstiks Archaisierung und Železnikars 
ist weiter überraschend, daß die Sprache in Kleinanzeigen nicht so "rein" war wie diejenige in den Leitartikeln oder anderen Beiträgen in dieser Zeitung (um einen korrekten Sprachgebrauch bemühte sich im Jahr 1895 der Redakteur D. Majaron ${ }^{60}$ ). Die Sprache in den Kleinanzeigen wurde besonders durch die Verwendung von Serbokroatismen geprägt, denn diese steigerten scheinbar ihre kommunikativen Leistungen. Die Slawisierung hörte jedoch mit den Übernahmen fehlender Wörter auf ${ }^{61}$ und erfaßte die morphologisch-syntaktische Struktur der Kleinanzeigen in Slovenski narod nicht. Deswegen fanden die archaischen slawischen Formen auf -ši hier keine Verwendung. Bewahrt wurden sie lediglich in Werbungstexten für die Aufnahme eines Zeitungsabonnements bzw. in Mitteilungen neuerschienener Bücher.

\subsubsection{Fachtexte}

In den Fachsprachen des 19. Jahrhunderts haben sich die Formen auf -č und -ši gut behaupten können. Das gilt hauptsächlich für Gerundien, da die infinite verbale Form ein angemessener Ersatz für die passivische Ausdrucksweise war. Die syntaktische Komprimierung verbreitete sich in unterschiedlichen Fachtextsorten nicht gleichmäßig, denn sie war von den ausgewählten sprachlichen Eigenschaften eines Textes abhängig als auch von der Berücksichtigung des Adressaten geprägt. Unter den slowenischsprachigen Fachtexten des 19. Jahrhunderts erreichten die Partizipialkonstruktionen ihre höchste Frequenz in den wissenschaftlichen Texten. Der wissenschaftliche Sprachgebrauch muß rational, präzise und ökonomisch sein (er muß in der Lage sein, das Wesentliche kurz und bündig darzustellen ${ }^{62}$ ). Demzufolge sind die wissenschaftlichen Texte für den Gebrauch von Partizipial- und Gerundialkonstruktionen bestens geeignet. Die oft gebrauchten Partizipien wurden hier sogar zu dem wichtigsten Merkmal der sprachlichen Intelektualisierung. Außer in populärwissenschftlichen verbreiteten sich die Formen auf - $\breve{c}$ und -ši auch in alltagssprachlichen Fachtexten, jedoch vor allem als fast obligatorische nachahmende syntaktische Ausdrucksweise, welche die Verständigung oft sogar erschwerte. Nicht etwa die Norm und/oder praktische

Abweichung von der Volkssprache - ließen zwar immer mehr nach, die partizipiale Ausdrucksweise blieb jedoch noch zur Zeit des Redakteurs I. Tavčar deutlich zu erkennen. 
Stilistik, sondern Sprachmode verursachte, daß sich in der zweiten Hälfte des 19. Jahrhunderts die Partizipien in allen Formen des fachlichen Kommunizierens durchsetzen konnten.

Die Gebrauchshäufigkeit der - ̌c- und -ši-Formen liegt in humanistischen und geisteswissenschaftlichen Texten höher als etwa in naturwissenschaftlichen und technischen Schriften; die letzteren kennen hauptsätzlich die Konstruktionen auf -č und -/aj/e. Demzufolge sind in den Fachtexten die Formen auf -ši seltener zu finden. Am auffälligsten ist das in Lehrbuchtexten: Ihr wesentliches Merkmal war eine logische und verständliche Syntax, welche F. Erjavec perfekt beherrschte. ${ }^{63}$

Tabelle 7: Durchschnittsfrequenz der Partizipial- und Gerundialkonstruktionen auf -č und -ši in Fachtexten

\begin{tabular}{|l|c|c|c|c|c|c|}
\hline \multirow{2}{*}{} & \multicolumn{6}{|c|}{ Fachtexte } \\
\cline { 2 - 7 } & \multicolumn{2}{|c|}{ Partizip } & \multicolumn{2}{c|}{ Gerundium } & \multicolumn{2}{c|}{ Gesamt } \\
\cline { 2 - 7 } & $\mathrm{p} / 700$ & $\mathrm{dp} / 10$ & $\mathrm{~g} / 700$ & $\mathrm{dg} / 10$ & $\mathrm{pg} / 700$ & $\mathrm{pg} / 10$ \\
\hline -č & 73 & 1,04 & 104 & 1,48 & 177 & 2,52 \\
\hline -ši & 5 & 0,07 & 53 & 0,75 & 58 & 0,82 \\
\hline -/aj/e & & & 24 & 0,34 & 24 & 0,34 \\
\hline Gesamt & 78 & 1,11 & 181 & 2,57 & 2599 & 3,68 \\
\hline
\end{tabular}

Die Durchschnittshäufigkeit der Partizipialkonstruktionen auf -č und -ši pro zehn Textseiten beträgt 3,68. Die Gerundien auf -č und -ši $(2,23)$ sind häufiger als Partizipien $(1,11)$; ein Partizip kommt auf 2,31 Gerundien (die Formen auf -/aj/e $(0,34)$ inbegriffen). Es überwiegen die Formen auf - $\breve{c}(2,52)$, während der Durchschnitt der Formen auf -ši bei 0,82 und der Formen auf -/aj/e bei 0,34 liegt. Die Formen auf -č und -ši stehen im Verhältnis $1,97: 1$ zueinander. Die Gerundien auf -č sind 1,4mal häufiger als dieselben Partizipien, während die Gerundien auf -ši 11 mal häufiger als die partizipialen -ši-Formen auftreten.

Die Frequenz von Partizipialkonstruktionen in Fachtexten ist im Vergleich zu den literarischen Texten um 60,7\% niedriger. Dabei darf nicht unberücksichtigt bleiben, daß unterschiedliche Klassen von Fachtexten auch unterschiedliche Frequenz von Partizipien aufweisen: In den wissenschaftlichen Texten $(6,2)$ als auch in Subklassen der alltagssprachlichen Texte (Amtssprache, 7,1) und der populärwissenschaftlichen Texte (Lebenslauf, Jubiäumsartikel, 6,1) erreichte sie ihre höchsten Werte (unter den Gerundien auf -ši erscheint nur hier die Form auf $-\varnothing /-\mathrm{v})$. 128. 
In den Fachtexten wurde aber nicht nur die Frequenz von Partizipialkonstruktionen auf $-\check{c}(-/ a j / e)$ und $-\check{s} i$ verändert, sondern es sind ebenso proportionale Veränderungen festzustellen.

Tabelle 8

\begin{tabular}{|c|c|c|c|c|c|}
\hline \multicolumn{6}{|c|}{ Fachtexte } \\
\hline \multirow{2}{*}{$\begin{array}{l}\text { Gesamtzahl der exzerpierten } \\
\text { Formen auf }-\check{c},-s \check{i},-/ a j / e\end{array}$} & \multicolumn{2}{|c|}{ Partizip } & \multicolumn{3}{|c|}{ Gerundium } \\
\hline & $-\check{c}$ & $-s ̌ \mathrm{i}$ & $-\check{c}$ & $-\mathrm{s} \mathrm{i}$ & $-/ a j / e$ \\
\hline 765 & $28,1 \%$ & $1,8 \%$ & $39,9 \%$ & $20,7 \%$ & $9,5 \%$ \\
\hline
\end{tabular}

Das Verhältnis zwischen den gerundial und partizipial gebrauchten Formen blieb demjenigen in den literarischen Texten ähnlich (etwa $7: 3$ ), allerdings verminderte sich die Anzahl von Gerundien (der Prozentsatz der Gerundien auf -ši sank um 6,8\% und jener der Gerundien auf -/aj/e um 9,3\%). Gleichzeitig nahm der Anteil der Gerundien auf -č um $16 \% \mathrm{zu}$.

\subsubsection{Alltagssprachliche Fachtexte}

Die Durchschnittshäufigkeit der Formen auf -č(-/aj/e) und -ši pro zehn Textseiten in diesen Texten beträgt 3,7. Es sind jedoch beträchtliche Unterschiede zwischen den Lehr- und Amtstexten festzustellen. Die Lehrtexte stehen der allgemeinen Kommunikation nahe, und demnach sind Partizipien hier nicht hochfrequent $(2,5)$. Überwiegend geht es um die Formen auf -č $(78,41 \%)$. Die -ši-Formen sind mit $11,51 \%$ und Gerundien auf -/aj/e mit 10,08\% vertreten. Die Hälfte von achtzehn ausgewerteter Autoren verwendet die Formen auf -ši überhaupt nicht; bei den anderen erscheint pro zehn Textseiten im Durchschnitt nur eine gerundiale oder partizipiale Form auf -ši. Die Amtstexte hingegen weisen eine wesentlich höhere Frequenz auf $(7,1$, denn die Formen auf -ši stellen sogar 39,53\% aller Partizipialkonstruktionen auf -č, (-/aj/e) und -ši dar. Das ist die Folge der damaligen Sprachmode, welche gerade in der Rechtssprache am stärksten zu beobachten war. Allerdings gibt es wesentliche Unterschiede in der Häufigkeit sowie auch im korrekten Gebrauch von Partizipialkonstruktionen bei einzelnen Autoren. ${ }^{64}$

Auch im Tschechischen ist die "relativ höchste Frequenz" von Partizipialkonstruktionen gerade für die Rechtssprache charakteristisch (E. Dvořak, Přechodníkové konstrukce v nové češtinĕ, Prag 1978, 106). In der slowenischen Rechtssprache des 19. Jahrhunderts vertreten den häufigen Gebrauch von Partizipialkonstruktionen vor allem B. Trnovec (Sodni obrazci, Triest 1886) und A. Levec (Zbirka obrazcev za slovensko uradovanje pri sodiščih, Ljubljana 1889). Trnovec übernahm die gerundialen Formen auf -č und -ši unter dem Einfluß der damaligen Sprachmode und beachtete dabei die grammatischen Gesetzmäßigkeiten nicht. I. Tavčar verwendete sie in den Rechtstexten (Slovenski pravnik, Klagenfurt 1883) unter dem Einfluß der Literatur, berücksichtigte dabei aber auch ihre schriftsprachliche Norm. 


\subsubsection{Populärwissenschaftliche Texte}

Unter dem Einfluß der literarischen Texte verbreiteten sich die Formen auf -č und -ši relativ schnell auch im populärwissenschaftlichen Sprachgebrauch, zuerst in den Lesebüchern für Gymnasien, die von J. Bleiweis und F. Miklosič herausgegeben wurden. $^{65}$ Im Lesebuch für die 7. Klasse (hrsg. von F. Miklošič, Wien 1858) liegt ihre Durchschnittshäufigkeit pro zehn Textseiten bei 12; 55,5\% aller Formen auf -č (-/aj/e) und -ši sind die Gerundien auf -ši. Die Lesebücher bemühten sich offensichtlich um eine häufigere Vewendung von Partizipien in der slowenischen Schriftsprache, sie wurden aber in den übrigen Lehrbüchern des 19. Jahrhunderts doch nicht akzeptiert, denn hier beträgt ihre Durchschnittsfrequenz pro zehn Textseiten nur 2,49. Die Gerundien auf -ši erscheinen in größerer Zahl nur noch bei I. Macun (Književna zgodovina Slovenskega Štajerja, Graz 1883; 48,1\% aller Formen). In den Lesebüchern für Grundund Sonntagsschulen treten die Formen auf -ši äußerst selten auf, denn die Bearbeiter berücksichtigten die bescheidenen sprachlichen Kenntnisse der Schüler, welche die partizipiale Ausdrucksweise in ihrer sprachlichen Umgebung nicht kennengelernt hatten. Ebenso selten verwendet wurden die Partizipien in Lehrbüchern für Mathematik (A. Matek), Geographie (J. Jesenko vewendet lediglich die Formen auf -č als Partizipien; F. Orožen selten nur die Gerundien), Biologie (F. Erjavec), Turnen (J. Zima) sowie auch in methodischen Handbüchern (z. B. für Naturlehre, L. Lavtar). Die Verwendung von Partizipien in sonstigen populärwissenschaftlichen Texten ist intensiver: die Durchschnittsfrequenz beträgt 3,41 , wovon $29,5 \%$ aller Formen auf - $\breve{c}$ (-/aj/e) und -ši gerundiale -ši-Formen sind (bei 77\% aller Gerundien). Am häufigsten sind die Partizipien bei F. Levec (90,4\%), J. Ulaga (90\%), I. Skuhala (80\%) und J. Marn (77,7\%) zu finden. Hoch über dem Durchschnitt liegt ihr Gebrauch in Lebensläufen $(6,1)$, insbesondere bei I. Tomšič (11) und M. Majar - Ziljski $(7,7)$. Hier überwiegen die gerundial gebrauchten Formen auf -č $(65,2 \%)$, es folgen die Formen auf -ši mit $20,3 \%$, wovon $1,69 \%$ die Formen auf $-\varnothing /$-v sind.

\subsubsection{Wissenschaftliche Texte}

Die Durchschnittsfrequenz von Partizipialkonstruktionen auf -č (-/aj/e) und -ši beträgt 6,2 und ist mit derjenigen in den Lebensläufen gleichzusetzen, denn ein Lebenslauf grenzt bereits an die wissenschaftlichen Texte und nähert sich dem wissenschaftlichen Sprachgebrauch. Die Partizipien und Gerundien stehen im Verhältnis $1: 4$ zueinander. Es treten 52,9\% gerundialer Formen auf -č, 21,5\% solcher auf -ši und 4,6\% solcher auf -/aj/e auf. Die gerundial gebrauchten Formen auf -/aj/e kommen im Vergleich zu anderen Fachtextklassen seltener vor, denn die Verfasser wissenschaftlicher Texte vermieden Dubletten auch in der Syntax und drückten demnach die Gleichzei-

65 Über Miklošičs Bemühungen um slowenische Lesebücher vgl. T. Hojan: Miklošič in slovenska gimnazijska berila. In: Miklošičev zbornik, Maribor 1991, 223-231. 
tigkeit in der Regel mit den Gerundien auf -č aus. Die Formen auf -ši fehlen lediglich bei S. Šubic und F. Ilešič. Ihren höchsten Anteil an sämtlichen untersuchten Partizipialund Gerundialkonstruktionen bei einzelnen Autoren erreichten sie aber bei F. Levec $(77,8 \%)$ und D. Trstenjak (50\%).

\subsubsection{Publizistische Texte}

Slowenische Zeitungen, Zeitschriften, Sammelbände und Almanache des 19. Jahrhunderts weisen eine äußerst unterschiedliche funktionalstilistische Beschaffenheit auf. In ihnen wurden selten nur publizistische Texte veröffentlicht. Die letzteren beschränkten sich eigentlich auf politisch orientierte Texte, Parteidokumente und -programme sowie auf Nachrichten und Meldungen, welche über das alltägliche Leben informieren sollten. Die Publizistik war mit den Texten der alltäglichen Kommunikation, ebenso aber auch mit den Fachtexten eng verbunden. Die Texte über Wirschaft und Verwaltung, sowie verschiedenartige aufklärende und sonstige Texte verdrängten die reine Publizistik. Am stärksten war das in spezialisierten religiösen und/oder politischen Zeitschriften zu beobachten, wo in manchen Texten der populärwissenschaftliche Sprachgebrauch überwog. In literarischen Zeitschriften sind sogar überhaupt keine Merkmale der publizistischen Sprache nachzuweisen. Da fast alle Zeitungen und Zeitschriften im 19. Jahrhundert auch literarische Texte veröffentlichten, kann von einem publizistischen Sprachgebrauch im 19. Jahrhundert wohl kaum die Rede sein; dieser befand sich erst am Anfang seiner Entwicklung. In dieser Hinsicht ist die Zeitschrift Novice (hrsg. von J. Bleiweis) zu erwähnen, die verschiedenartigsten Texte herausbrachte. Die erste slowenische politische Zeitschrift Slovenija (1848-1850; hrsg. von M. Cigale) orientierte sich bereits stärker an der Publizistik, vor allem galt das aber für "die angesehenste slowenische Zeitung" Slovenski narod (1868-1918; hrsg. von A. Tomšič, später von J. Jurčič, I. Tavčar, I. Železnikar, D. Majaron, u.a.). Von großer Bedeutung für die Entwicklung der slowenischen publizistischen Sprache waren außerdem folgende Publikationen: Slovenec (1873; ein politisches Blatt für die slowenische Nation), Gospodarski glasnik za Štajersko (1884; ein Presseorgan für Landwirtschaft und Landeskultur), Slovan (1884-1887, Redakteur A. Trstenjak; ein politisches und literarisches Blatt) und Zgodnja danica (1849-1902, Redakteur L. Jeran). Es gab zu dieser Zeit allerdings auch mehrere sprachlich bzw. funktionalstilistisch stark heterogene Publikationen: Pravi Slovenec (1849, hrsg. von Malavašič), Naprej (1863, hrsg. von Levstik), Slovenski prijatelj (1852-1883, hrsg. von Einspieler), das religiöse Blatt Duhovni pastir (18841921), Učiteljski tovarš (hrsg. von Praprotnik; ein Blatt für Schule und Heim). Hauptsächlich literarische Texte veröffentlichten Glasnik (1858-1868, hrsg. von Janežič), Zvon (1870; 1876-1880, hrsg. von Stritar), Ljubljanski zvon (1884-1941), Dom in svet (1888-1944), oder mehrere Schülerzeitungen (Torbica). Solche funktionalstilistische Gliederung der Presse im 19. Jahrhundert beeinflußte auch den Gebrauch von -č- und -ši-Formen. Am häufigsten traten diese in überwiegend literarischen Zeitschriften auf; von hier aus verbreiteten sie sich auch in die publizistischen Texte, wo sie 
als sprachlich moderne morphologisch-syntaktische Ausdrucksweise akzeptiert wurden. Die Durchsetzung der Formen auf -ši war außerdem von der sprachlichen Toleranz der Redakteure abhängig. Besonders häufig wurden die Partizipial- und Gerundialkonstruktionen in Novice (Bleiweis) angenommen. Im Jahr 1843 waren in dieser Zeitschrift fast keine -ši-Formen zu finden. Später veröffentlichten sie allerdings mehr literarische Texte, und dadurch nahm die Anzahl der verwendeten -ši-Formen auch in nichtliterarischen zu. Bleiweis war in bezug auf den Sprachgebrauch äußerst tolerant und publizierte auch in verschiedenen Dialekten geschriebene Texte, wohl aus prinzipiellen Gründen, denn Novice sollte eine Zeitschrift für alle Slowenen sein. Anfangs konnte er sich für solche Prinzipien zwar einsetzen, nachdem er aber die literarischen Texte in einem größeren Umfang veröffentlicht hatte, gewann besonders die Frage des schriftsprachlichen Sprachgebrauchs in der Presse an Aktualität (O. Caf, 1845). Bleiweis befolgte seitdem die sprachliche Norm, kodifiziert in der Grammatik von Muršec (1847). ${ }^{66}$ Die partizipiale Ausdrucksweise und damit der Gebrauch von č- und ši-Formen fand demnach in Novice schnell Verbreitung.

Der häufige Gebrauch von -č- und -ši-Formen in der Presse war in den 50er und 60 er Jahren außerdem die Folge von panslawistischen Ideen in der slowenischen Kultur und Politik. Diese regten die Suche nach der sprachlichen und nationalen Identität im gesamtslawischen Raum an. In sprachlicher Hinsicht reichten sie in die Vergangenheit bis hin zum Altkirchenslawischen. Für die Unterstützung solcher Bemühungen waren die Partizipien als archaische und ursprünglich slowenische sprachliche Elemente gut geeignet. Am stärksten kamen solche Bestrebungen in Slovenski narod zum Ausdruck: Hier wurden die Lexik, Syntax und Morphologie unter dem Einfluß des Russischen und Kroatischen bewußt archaisiert und slawisiert. ${ }^{67}$ Die Zeitschrift Slovenec war hingegen politisch anders orientiert; demzufolge unterschied sie sich von Slovenski narod auch in sprachlicher Hinsicht. Die Archaisierung wurde bewußt vermieden; der Sprachgebrauch näherte sich der alltäglichen, dem Volk verständlichen Sprache an, und demnach wurden die -č- und -ši-Formen selten verwendet. Die "Jugoslawisierung" der slowenischen Sprache erreichte ihren Höhepunkt in der Zeitschrift Zora (hrsg. von Razlag; ein jugoslawisches Unterhaltungsblatt, "jugoslovanski zabavnik"). Thr Sprachgebrauch war äußerst unlebendig ("lunin jezik" - eine Mondsprache) und wurde von J. Bleiweis, F. Cegnar und L. Svetec sehr kritisch beurteilt. In bezug auf die Formen auf -č und -ši war er allerdings interessant, denn es zeigen sich starke kroatisch-kajkavische Einflüsse auf die Verwendung von funktional unterschiedlichen und hochfrequenten -ši-Formen.

66 Ein unbekannter Kritiker (angeblich Bleiweis) erklärte diese Grammatik für "slowenisch" (Novice, 1848) und nicht etwa für regional stairisch; außerdem empfahl er sie allen Slowenen. Muršecs Grammatik hatte demnach einen starken Einfluß auf den Sprachgebrauch in Novice - bis zu den heftigen Bemühungen um die neuen Formen ("novooblikarski vihar", Novice 1850, 1851).

67 J. Vošnjak, J. Sernec, der erste Redakteur A. Tomšič und noch weitere Intelektuelle in der Steiermark. Vgl. A. Breznik: O časnikarski slovenščini. In: Jezikoslovne razprave (hrsg. von J. Toporišič), Ljubljana 1982, 133-161. 
Entscheidend für den Gebrauch der betreffenden Formen war auch die jeweilige Redaktionspolitik. Die Zeitschriften, deren Redakteur oder Mitarbeiter F. Levstik war (Naprej, Slovenski narod, Slovenec, Pavliha, Vrtec), weisen eine hohe Frequenz der Partizipien auf. Das gilt sogar für die 50er und für die erste Hälfte der 60er Jahre, als Levstiks literarischer Sprachgebrauch noch an die einfache Volkssprache angepaßt war und Partizipien nur selten vorkamen. ${ }^{68}$ Auch A. Janežič und M. Cigale befürworteten den Gebrauch von Partizipial- und Gerundialkonstruktionen. ${ }^{69}$ Interessanterweise fehlen die Formen auf -č in Pravi Slovenec (hrsg. von Malavašič). Eben in dieser Zeitschrift erschien die Grammatik von Janežič, die über die Partizipial- und Gerundialkonstruktionen auf -č und -ši gut informierte. In den religiösen Zeitschriften wurden đie modischen Formen nicht empfohlen, so daß syntaktisch traditionelle Nebensätze und Satzreihen überwiegen, ebenso aber auch Infinitive oder passivische Partizipien als syntaktische Kondensatoren (Duhovni pastir, Angeljček, Zgodnja danica, Dom in svet). Diesbezüglich interessant ist Cvetje $z$ vrtov sv. Frančiška ("mesečni list za verno slovensko ljudstvo, zlasti za ude tretjega reda sv. Frančiška", hrsg. von P. Evstahij Ozimek, seit 1884 (5. Band, V. Jahrgang) von P. Stanislav Škrabec). Auf dem Umschlag dieser Zeitschrift wurden sprachwissenschaftliche Schriften von Škrabec veröffentlicht, die mehr Partizipien aufweisen als in den religiösen Texten derselben Zeitschrift gewöhnlich vorkamen. Ein Beweis dafür, daß sich die syntaktischen Kondensatoren auf -č und -ši nicht einmal in Škrabecs Zeitschrift zu festigen vermochten, obwohl er sie als Sprachwissenschaftler in den wissenschaftlichen Schriften oft verwendete.

Es geht bereits aus der Analyse der Lehrbücher hervor, daß die Formen auf -ši in den Schultexten nicht akzeptiert wurden - dasselbe gilt auch für die Schulpresse. In Einspielers Šolski prijatelj, ${ }^{70}$ Praprotniks Učiteljski tovarš bzw. Popotnik (hrsg. in Celje (1880-1883) und Maribor (1883-1900); Redakteur M. Nerat) wurden sie fast ausnahmslos durch andere syntaktische Mittel ersetzt, so daß die selten verwendeten Formen unbemerkt und ohne einen stärkeren Einfluß auf den Sprachgebrauch blieben. Be-

Vgl. dazu einen niedrigen Anteil der Formen auf -č und -ši in Martin Krpan (nur ein Gerundium auf -ši), in Deseti brat oder in seinen übrigen frühen literarischen Texten. "Levstikov časnikarski jezik se loči od njegovega umetnostnega jezika" (A. Breznik, ebd., 138); hinsichtlich der Verwendung von -č- und -ši-Formen wurde diese Feststellung bestätigt. Während Levstiks dritter Schöpfungsphase (vgl. M. Orožen, Levstikovi pogledi na jezik) konnte er in keiner slowenischen Zeitschrift mitwirken, seine Lektorentätigkeit bei der Zeitschrift Vrtec (bis 1875) beweist allerdings, daß er in den publizistischen Texten die Frequenz von - $\breve{c}$ - und -ši-Formen Jahr für Jahr verstärkte, veranlaßt durch sein vertieftes Studium des Altkirchenslawischen.

"Kar jezik zadene, se bodo $v$ Slovenijo, da ime po pravici zasluži, sestavki $v$ vsakim jeziku prejemali, če je le slovenski, naj se v tem ali unim kraji naše mile domovine glasi." (Slovenija, 1848 , Nr. 1, 1.) Das bedeutete zugleich, daß die partizipiale Ausdrucksweise redaktionell nicht verdrängt werden sollte und daß die Verfasser diesbezüglich freie Entscheidung treffen konnten. In den publizistischen Texten von M. Cigale kommen die Formen auf -ši oft vor; J. Trdina gebrauchte sie hauptsächlich in seiner Literatur. Bei den übrigen Mitarbeitern sind sie seltener zu finden.

70 Unter diesem Namen erschien die Zeitschrift von 1852 bis 1854 in Klagenfurt; 1855 trägt sie den Namen Prijatelj, 1856-1883 Slovenski prijatelj. 
wahrt wurden lediglich seltene Archaismen von präfigierten Verben (prišedši, prebravši, podelivši . Gegen Ende des 19. Jahrhunderts wurden diese Formen auch in den Schülerzeitschriften immer seltener gebraucht. In Torbica (1862-1864) kommen sie noch oft vor, nicht selten jedoch unkorrekt gebildet, während sie in Vesna (1892) von einigen ihrer Mitarbeitern, die s̀päter zu anerkannten Autoren wurden (K. Robida, R. Murnik), nur selten verwendet wurden.

Die partizipiale und gerundiale Ausdrucksweise bewahrte sich jedoch in der Unterhaltungspresse (Rogač, 1886-1888, hrsg. von S. Magolič; Šaljivi Jaka, 1892, Unterhaltungstexte gesammelt und bearbeitet von A. Kosi), und zwar nicht als stilistische Mittel zum Ausdruck der Komik (Parodie auf die ungewöhnliche Redeweise, falsche Ableitung, Wortspiele usw.), sondern als wirksame syntaktische Kondensatoren, wie etwa in den literarischen Texten. Die hohe Frequenz der Partizipien überrascht, denn Scherztexte waren unter den einfachen Leuten verbreitet und wurden erst später veröffentlicht, wobei die partizipiale Ausdrucksweise ihre Lächerlichkeit nicht vermindert. Es stellt sich die Frage, ob die Bearbeiter in der Tat nur die schriftsprachlichen Formen normgerecht verwendeten, oder ob diese Formen am Rand des slowenischen dialektalen bzw. gesprochenen Sprachgebrauchs doch lebendig waren.

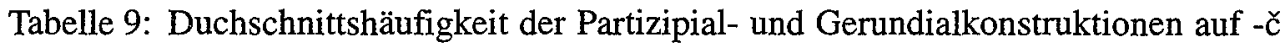
und -ši in Zeitungen, Zeitschriften und Sammelbänden

\begin{tabular}{|l|c|c|c|c|c|c|}
\hline \multicolumn{5}{|c|}{ Veröffentlichungen in Zeitungen, Zeitschriften und Sammelbänden } \\
\hline & \multicolumn{2}{|c|}{ Partizip } & \multicolumn{2}{c|}{ Gerundium } & \multicolumn{2}{c|}{ Gesamt } \\
\cline { 2 - 7 } & $\mathrm{p} / 700$ & $\mathrm{dp} / 10$ & $\mathrm{~g} / 700$ & $\mathrm{dg} / 10$ & $\mathrm{pg} / 700$ & $\mathrm{pg} / 10$ \\
\hline -č & 164 & 2,34 & 183 & 2,61 & 347 & 4,95 \\
\hline - $\mathrm{si}$ & 14 & 0,2 & 152 & 2,17 & 166 & 2,37 \\
\hline -/aj/e & & & 48 & 0,68 & 48 & 0,68 \\
\hline Gesamt & 178 & 2,54 & 383 & 5,46 & 561 & 8 \\
\hline
\end{tabular}

Die Durchschnittsfrequenz der Partizipialkonstruktionen auf -č und -ši pro zehn Textseiten der slowenischen Pressetexte im 19. Jahrhundert (36 exzerpierte Titel) beträgt 8. Die Gerundien auf č und -ši $(4,78)$ sind häufiger als die Partizipien $(2,54)$; sie stehen in einem Verhältnis $2,1: 1$ zueinander, miteinbezogen auch die Gerundien auf -/aj/e. Es überwiegen die Formen auf -č $(4,95)$; die Formen auf -ši kommen zweimal seltener vor $(2,37)$, und auch die Formen auf -/aj/e sind äußerst selten $(0,68)$. Die Formen auf -č und -ši sind fast verhältnisgleich vetreten $(1,2: 1)$, während die Formen auf -/aj/e in 20,7\% der Belege zum Ausdruck der Gleichzeitigkeit gebraucht werden. Unter den Formen auf -č sind Partizipien und Gerundien verhältnisgleich vertreten $(1: 1,1)$, während unter den Formen auf -ši Partizipien überwiegen $(91,57 \%$ ).

Es ist aus der Tabelle ersichtlich, daß die Gerundien auf -/aj/e relativ selten auftreten. Sie sind hauptsächlich ein Merkmal der literarischen Texte in folgenden Publikationen: Glasnik slovenskega slovstva, Slovenski narod, Zvon und Ljubljanski zvon. In 
der Publizistik kam es dagegen zu einer Verallgemeinerung der Formen auf $-\check{c}$, die generell zum Ausdruck der Gleichzeitigkeit dienten. Die verkürzte Variante der -ši-Form $(-\varnothing /-v)$ ist äußerst selten. Sie ist lediglich in Slovenski narod, Naprej und Ljubljanski zvon zu finden.

Die Durchschnittsfrequenz der Formen auf -č und -ši in den Pressetexten ist mit derjenigen in den literarischen Texten, welche teilweise auch in der Presse veröffentlicht wurden, vergleichbar. Die statistischen Ergebnisse bestätigen die These, daß die Partizipial- und Gerundialkonstruktionen in der Presse unter dem Einfluß der literarischen Texte eingesetzt wurden. Ihre extrem hohe Häugfigkeit ist beinahe als übertrieben $\mathrm{zu}$ beurteilen, denn sie errreicht fast die literarischen Texte $(8: 9,36)$. Bei den vielen, sprachlich meist weniger gebildeten Zeitungslesern stieß sie schell auf Widerstand, ${ }^{71}$ und die Folge war, daß einige Redakteure die Formen auf -ši bewußt abzulehnen versuchten. Trotzdem ist die Durchschnittsfrequenz von -ši-Formen in der Presse mit derjenigen in den literarischen Texten fast gleichzusetzen $(2,17: 2,6)$. Die betreffenden Formen wurden demnach in allen Funktionalbereichen der slowenischen Schriftsprache erfolgreich wiederbelebt; dasselbe gilt auch für den publizistischen Sprachgebrauch, welcher "po svoji vrednosti najnižja, po svojem vplivu pa najmočnejša vrsta jezika"72 ist und welcher die Ansprüche der hinsichtlich der Ausbildung zahlreichsten Leserschaft zufriedenzustellen versucht.

Der Anteil der einzelnen Formen an der Gesamtzahl der exzerpierten Belege ist mit dem literarischen Sprachgebrauch vergleichbar:

Tabelle 10

\begin{tabular}{|c|c|c|c|c|c|}
\hline \multicolumn{6}{|c|}{ Texte in Zeitungen, Zeitschriften und Sammelbänden } \\
\hline \multirow{2}{*}{$\begin{array}{l}\text { Gesamtzahl der exzerpierten Formen } \\
\text { auf -č, -ši, -/aj/e }\end{array}$} & \multicolumn{2}{|c|}{ Partizip } & \multicolumn{3}{|c|}{ Gerundium } \\
\hline & $-\check{c}$ & $-\check{s ̌ i}$ & $-\check{c}$ & $-s ̌ i$ & -laj/e \\
\hline 1767 & $29,2 \%$ & $2,5 \%$ & $32,7 \%$ & $27,1 \%$ & $8,5 \%$ \\
\hline
\end{tabular}

71 Vgl. dazu den Ärger der Leser, welche Levstiks puristische Bestrebungen in Vrtec nicht akzeptieren wollten. Die Redaktion mußte zusichern, daß die Zeitschrift bei ihrem früheren Stil bleiben wird, daß sie "svoj/o/ prejšnj/o/, slovenskemu ljudstvu bolj navadn/o/ pisav/o/" (1875, Nr. 2, 32) beibehalten wird. Levstiks Enflüsse auf den Sprachgebrauch verringerten sich danach wesentlich, und in den 80er Jahren erschienen die Formen auf -ši in Vrtec fast nie mehr. Diese Rückkehr zur gesprochenen Sprache wurde auch in Duhovni pastir gelobt: "Vso to zdravo duševno hrano podaja "Vrtec" $v$ jako čedni posodi: $v$ jeziku lepem, pravilnem in prostem. $V$ tej zadevi se je list zadnja leta I!/ jako poboljšal; naj bi le se zanaprej vedno gledal na to, da mu je pisava na moč jasna i razumljiva malim šolarjem." (1884, 3. Band, 159). Die Beurteilung kam aus den kirchlichen Kreisen (Redakter A. Krzič), die Levstiks Archaisierung nie zugeneigt waren und in der Regel auch die Partizipialkonstruktionen auf $-\check{c}$ und -ši vermieden. Im 12. Band von Duhovni pastir (1884, S. 585-644) kommt die Form auf -ši nicht einmal vor. 
Die in der Tabelle dargestellten Durchschnittsproportionen weisen erhebliche Abweichungen in einzelnen Pressepublikationen auf. Am stärksten sind sie beim Gebrauch der partizipial $(31,8 \%)$ und/oder gerundial $(68,2 \%)$ gebrauchten Formen zu beobachten. Am seltesten sind die Gerundien in Slovenski prijatelj (72,7\%:27,2\%), Popotnik (70\% : 30\%), Duhovni pastir (57,1\%: 42,9\%), Gospodarski glasnik (57\%:43\%), Zgodnja danica $(53,2 \%: 46,8 \%)$, Vesna $(52,2 \%: 47,8 \%)$ und Angeljček $(41,6 \%: 58,4 \%)$. Dabei muß berücksichtigt werden, daß die Gerundien auf -ši äußerst selten (Popotnik 5\% Duhovni pastir 7,1\%) oder überhaupt nicht (Slovenski prijatelj, Angeljček) vorkommen. In größerem Umfang erscheinen diese in Vrtec unter der Redaktion von F. Levstik $(15,4 \%: 84,6 \%)$, ebenso aber auch in Torbica $(18,7 \%: 81,3 \%)$, wo der Anteil der Gerundien auf -ši am höchsten ist $(56,2 \%)$.

\section{Chronologische Einordnung der Texte}

Es wurde versucht, die relevantesten literarischen und sprachlichen Bedingungen, welche im 19. Jahrhundert die Wiederbelebung der Formen auf -č und -ši in der slowenischen Schriftsprache als auch ihre spätere Verdrängung aus dem morphologisch-syntaktischen System veranlaßt hatten, zu berücksichtigen. Entscheidend für das erneut erweckte Interesse an diesen Formen war ihre feste Stellung in der ostslowenischen Variante der slowenischen Schriftsprache. Die neu gewonnenen Erkentnisse über eine archaische Variante der slowenischen Sprache, die sich im ungarischen Teil der österreichisch-ungarischen Monarchie nicht nur bewahrt, sondern auch eine reiche literarische Tätigkeit entwickelt hatte, warf die Frage über die Angemessenheit zweier schrifltlicher Normen auf. Es wurde am Anfang des 19. Jahrhunderts notwendig, die Slowenen auf beiden Seiten der Mur in kultureller und sprachlicher Hinsicht in Beziehung zu setzen. ${ }^{73} \mathrm{Zu}$ jener Zeit gab es nämlich weder unmittelbare sprachliche Einflüsse noch gegenseitige Übernahmen, obwohl die Sprachwissenschaftler (J. Kopitar, M. Čop) auf das morphologische, syntaktische und lexikalische System der archaischen ostslowenischen Schriftsprache sowie auf einige im Zentrum bereits unterlassene Besonderheiten verwiesen. Aufgrund der schriftsprachlichen Kontinuität im ostslowenischen Sprachraum wurde die ostslowenische Schriftsprache als Vorbild der sprachlichen Korrektheit betrachtet. Während er ersten Entwicklungsperiode sind keine wesentlichen Veränderungen im Gebrauch der Formen auf -č und -ši festzustellen. Die zweite Entwicklungsperiode brachte allerdings unerwartete Wiederbelebungsversuche der gerundialen Formen auf -ši im zentralslowenischen Sprachraum hervor. M. Ravnikar war daran so begeistert, daß er sie in den Bibelerzählungen mit dem Titel Zgodbe 
svetega pisma za mlade ljudi bereits 1815 verwendete. Damit fang ein Zeitabschnitt der intensiven Bestrebungen für den Gebrauch der Formen auf č und -ši in der zentralslowenischen Schriftsprache an. Die Gegenüberstellung zweier unterschiedlicher syntaktischer Systeme veranlaßte indirekt aber auch die spätere Vereinheitlichung beider Typen der slowenischen Schriftsprache. Mit der Grammatik von F. Metelko

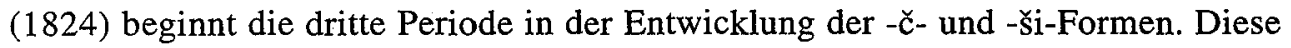
Grammatik regelte nämlich die aspektgerechte Derivation von Partizipien und erklärte ihre funktionalstilistische Prägung. Der frühere "amateurhafte" Partizipialgebrauch wurde dadurch übertroffen. Bedeutend für die Entwicklung der betreffenden Formen ist außerdem die Grammatik von A. Janežič (1863, zweite Auflage), denn seit dieser Grammatik galten die Formen auf -č und -ši als schriftsprachlich normiert. Der Gebrauch von Partizipien wurde von A. Janežič ausführlich erklärt, und da die Grammatik zugleich ein Lehrbuch für den Unterricht der slowenischen Sprache an den Mittelschulen war, wurde die partizipiale Ausdrucksweise zu erkennbaren Merkmalen der sprachlichen Ausbildung. Stark geprägt ist die dritte Entwicklungsperiode durch die sprachwissenschaftliche und literarische Tätigkeit von F. Levstik. In seinem Werk Tugomer ist der Gebrauch von Partizipialkonstruktionen der Gesetzmäßigkeiten des Altkirchenslawischen völlig untergeordnet. Eine solche sprachliche Archaisierung wurde von den Zeitgenossen Levstiks nicht akzeptiert, und das Jahr 1876 bedeutet das Ende der vierten Periode in der Entwicklung von -č- und -ši-Formen. In Levstiks Tugomer erreichten sie ihre höchste Frequenz und entwickelten eine bemerkenswerte funktionale Vielfältigkeit, die sonst nicht zu konstatieren ist. Während der fünften Entwicklungsperiode (1877-1897) kamen die Formen auf -č und -ši zwar oft vor, obwohl es immer mehr Autoren gab, welche sie schon völlig aufgegeben hatten. Insbesondere I. Cankar war ein entschiedener Gegner der partizipialen Ausdrucksweise. 1897 veröffentlichte er in Slovenski narod das Manifest einer neuen literarischen Richtung (das Essay Naša lirika), und dieser Text brachte zugleich einen neuen Sprachstil hervor. Er brach mit der sprachlichen Tradition des Realismus und Naturalismus und verdrängte sämtliche Reste der Vergangenheit, darunter auch die Gerundien auf -ši, welche am Ende des 19. Jahrhunderts in der slowenischen Schriftsprache immer seltener verwendet wurden. Außerdem wurden sie von den synchronen Sprachwissenschaftlern (Breznik und seine Grammatik aus dem Jahre 1916) lediglich als sprachliche Randerscheinungen akzeptiert. Die Entwicklung der Formen auf -č und -ši wurde im Jahr 1916 demnach (vorläufig) beendet. 
Tabelle 11: Perioden in der Entwicklung der Formen auf -č und -ši in der slowenischen Schriftsprache des 19. Jahrhunderts

\begin{tabular}{|l|l|}
\hline Zeitabschnitt & Entwicklungsperioden \\
\hline bis 1815 & I. Periode: Sprachliche Geschlossenheit \\
\hline $1815-1824$ & II. Periode: Unkritische Übernahmen und Wiederbelebungsversuche \\
\hline $1825-1862$ & III. Periode: Korrekturen und sprachliche Aufgeschlossenheit \\
\hline $1863-1876$ & IV. Periode: Normierungsversuche \\
\hline $1877-1897$ & V. Periode: Sprachmode \\
\hline nach 1897 & VI. Periode: Nachlassen und Aufhebung \\
\hline
\end{tabular}

3.1 I. Periode: Sprachliche Geschlossenheit (Vgl. Tabelle 3)

3.2 Tabelle 13

\begin{tabular}{|c|c|c|c|c|c|c|}
\hline \multicolumn{7}{|c|}{$\mathrm{n}$ und Wiederbelebungsversuc } \\
\hline \multirow{3}{*}{$\begin{array}{l}\text { Verfasser } \\
\text { M. Ravnikar }\end{array}$} & \multirow{3}{*}{\begin{tabular}{|l|} 
Titel \\
$\begin{array}{l}\text { Zgodbe svetega pisma za mlade ljudi, 1815- } \\
1817\end{array}$ \\
\end{tabular}} & \multirow{3}{*}{\begin{tabular}{|c|}
$\mathrm{pg} / 100$ \\
209 \\
\end{tabular}} & \multirow{2}{*}{\multicolumn{2}{|c|}{$\begin{array}{c}\text { Partizip } \\
-\breve{c} \quad-s \mathrm{i}\end{array}$}} & \multirow{2}{*}{\multicolumn{2}{|c|}{$\begin{array}{l}\text { Gerundium } \\
-\check{c} \quad-\check{s} i\end{array}$}} \\
\hline & & & & & & \\
\hline & & & 59 & 40 & 27 & 83 \\
\hline J. Ja & Sad & 71 & 47 & $E$ & 9 & 13 \\
\hline U. Jarnik & Jedro kershanski & 77 & 50 & 3 & 15 & \\
\hline Dajnko & troki/.../, 1824 & 65 & 39 & 1 & 24 & \\
\hline Gesamt & & 422 & 195 & 46 & 75 & 106 \\
\hline
\end{tabular}

\subsection{Tabelle 14}

\begin{tabular}{|c|c|c|c|c|c|c|c|c|}
\hline \multicolumn{9}{|c|}{ III. Periode: Korrekturen und sprachliche Aufgeschlossenheit } \\
\hline \multirow{2}{*}{ Verfasser } & \multirow[t]{2}{*}{ Titel } & \multirow[t]{2}{*}{ Jahr } & \multirow[t]{2}{*}{$\mathrm{pg} / 100$} & \multicolumn{2}{|c|}{ Partizip } & \multicolumn{3}{|c|}{ Gerundium } \\
\hline & & & & $-\check{c}$ & $-\breve{s i}$ & $-\check{c}$ & -ši & $a j / e$ \\
\hline V. Stanič & $\begin{array}{l}\text { Perstavnik nekterih cerkvenih in } \\
\text { drugih pesem } / . . /\end{array}$ & 1826 & 69 & 46 & 0 & 23 & 0 & 0 \\
\hline J. Zalokar & $\begin{array}{l}\text { Dvoje bukve Tomaža Kempčana, to } \\
\text { je Hiša ubozih } / . . . /\end{array}$ & 1826 & \begin{tabular}{|c|}
18 \\
$(30)$ \\
\end{tabular} & 13 & 0 & 3 & 0 & 2 \\
\hline F. Veriti & Shivljenje Svetnikov $/ . . . /$ & 1828 & 33 & 22 & 0 & 8 & 0 & 3 \\
\hline J. Burger & Pomoč v sili ali leseni križ & 1832 & $\begin{array}{c}19 \\
(40)\end{array}$ & 9 & 0 & 3 & 0 & 5 \\
\hline F. Pirc & Krajnski vertnar $/ . . . /$ & 1834 & $2(30)$ & 2 & 0 & 0 & 0 & 0 \\
\hline A. Lah & Leseni križec & 1835 & $\begin{array}{c}22 \\
(40)\end{array}$ & 16 & 0 & 6 & 0 & 0 \\
\hline J. Cigler & Sreča v nesreči & 1836 & 19 & 7 & 0 & 10 & 0 & 2 \\
\hline
\end{tabular}




\begin{tabular}{|c|c|c|c|c|c|c|c|c|}
\hline L. Volkmer & Fabule in pesmi & 1836 & $\begin{array}{c}23 \\
(20) \\
\end{array}$ & 5 & 0 & 17 & 1 & 0 \\
\hline J. Žemlja & $\begin{array}{l}\text { Sedem sinov. S slovečo elegijo g. } \\
\text { Graya }\end{array}$ & 1843 & $\begin{array}{c}22 \\
(20)\end{array}$ & 14 & 0 & 6 & 1 & 1 \\
\hline F. Malavašič & Erasem is jame & 1845 & $\begin{array}{c}16 \\
(36) \\
\end{array}$ & 4 & 1 & 1 & 5 & 5 \\
\hline J. Volc & $\begin{array}{l}\text { Stoletna pratika devetnajstega } \\
\text { stoletja od 1801-1901 (2. natis) }\end{array}$ & 1847 & 21 & 0 & 0 & 0 & 0 & 4 \\
\hline Š. Kocjančič & 26 povesti za mlade ljudi & 1848 & 30 & 17 & 0 & 4 & 1 & 8 \\
\hline M. Majar & $\begin{array}{l}\text { Pravila kako izobraževati ilirsko } \\
\text { narečje /... }\end{array}$ & 1848 & $\begin{array}{c}31 \\
(50) \\
\end{array}$ & 4 & 0 & 20 & 6 & 1 \\
\hline F. Metelko & $\begin{array}{l}\text { Raslaganje Svetiga evangelija S. } \\
\text { Matevža I. del }\end{array}$ & 1849 & 59 & 32 & 0 & 21 & 2 & 4 \\
\hline J. Muršec & Bogočastje sv. katoliške cerkve & 1850 & 43 & 15 & 4 & 12 & 10 & 2 \\
\hline O. Caf & Robinson Mlajši & 1851 & 103 & 17 & 1 & 19 & 37 & 29 \\
\hline M. Vilhar & Slovenski koledar za leto 1851 & 1851 & $4(70)$ & 2 & 1 & 0 & 1 & 0 \\
\hline J. Zalokar & Umno kmetovanje in gospodarstvo & 1854 & 31 & 23 & 0 & 4 & 3 & 1 \\
\hline I. Orožen & Celska kronika & 1854 & $9(30)$ & 6 & 1 & 0 & 0 & 2 \\
\hline D. Trstenjak & Mesec Marije /... & 1856 & 32 & 12 & 0 & 14 & 0 & 6 \\
\hline A. Wolf & Sveto pismo (nova zaveza) & 1856 & 26 & 18 & 0 & 6 & 0 & 2 \\
\hline F. Levstik & Popotovanje od Litije /.../ & 1858 & $\begin{array}{r}12 \\
(30) \\
\end{array}$ & 7 & 0 & 1 & 1 & 3 \\
\hline F. Levstik & Napake slovenskega pisanja & 1858 & $\begin{array}{c}17 \\
(54)\end{array}$ & 7 & 0 & 4 & 1 & 5 \\
\hline F. Levstik & Martin Krpan & 1858 & $\begin{array}{c}14 \\
(22) \\
\end{array}$ & 3 & 0 & 7 & 1 & 3 \\
\hline P. Hicinger & Močni baron Ravbar & 1858 & $1(16)$ & 0 & 0 & 0 & 0 & 1 \\
\hline M. Vilhar & Pesmi Miroslava Vilharja & 1860 & $7(15)$ & 2 & 0 & 1 & 2 & 2 \\
\hline L. Jeran & Postne pridige & 1861 & $8(30)$ & 4 & 0 & 4 & 0 & 2 \\
\hline A. Lesar & $\begin{array}{l}\text { Katekizem ali keršanski katoliški } \\
\text { nauk }\end{array}$ & 1862 & 94 & 23 & 0 & 57 & 14 & \\
\hline V. Zarnik & Don Quihotte della Blatna vas & 1862 & $7(24)$ & 1 & 0 & 2 & 2 & 2 \\
\hline F. Cegnar & Babica & 1862 & 68 & 15 & 0 & 11 & 25 & 17 \\
\hline G. Krek & Poezije & 1862 & $8(15)$ & 4 & 0 & 1 & 3 & 0 \\
\hline $\begin{array}{l}\text { Zeitungen, } \\
\text { Zeitschriften, } \\
\text { Sammel- } \\
\text { bände } \\
\end{array}$ & $\begin{array}{l}\text { Novice, Glasnik slov. slovstva, } \\
\text { Vedež, Zora, Slovenija, Pravi } \\
\text { Slovenec, Slovenski glasnik, } \\
\text { Učiteljski tovarš }\end{array}$ & $\begin{array}{c}1843 \\
- \\
1862\end{array}$ & 73 & 22 & 4 & 10 & 20 & 17 \\
\hline Gesamt & \multicolumn{2}{|c|}{$1826-1862$} & 945 & 393 & 12 & 275 & 122 & 143 \\
\hline
\end{tabular}




\subsection{Tabelle 15}

IV. Periode: Normierungsversuche

\begin{tabular}{|c|c|c|c|c|c|c|c|c|}
\hline \multirow{3}{*}{\begin{tabular}{|l} 
Verfasser \\
F. Levstik \\
\end{tabular}} & \multirow{3}{*}{\begin{tabular}{|l|} 
Titel \\
Deseti Brat \\
\end{tabular}} & \multirow{3}{*}{$\begin{array}{r}\text { Jahr } \\
1863 \\
\end{array}$} & \multirow{3}{*}{\begin{tabular}{|l|}
$\mathrm{pg} / 100$ \\
$7(17)$ \\
\end{tabular}} & \multicolumn{2}{|c|}{ Partizip } & \multicolumn{3}{|c|}{ Gerundium } \\
\hline & & & & \multicolumn{2}{|r|}{$-\mathrm{s} \mathrm{i}$} & \multicolumn{2}{|r|}{-ši } & - Iaj/e \\
\hline & & & & 5 & 0 & 1 & 1 & 0 \\
\hline J. Jurčič & Jurij Kotjak & 1864 & $\begin{array}{c}42 \\
(50) \\
\end{array}$ & 12 & 0 & 4 & 10 & 16 \\
\hline B. Tomšič & Lahkoverni & 1864 & $\begin{array}{c}14 \\
(20)\end{array}$ & 4 & 1 & 3 & 4 & 2 \\
\hline M. Majar & Sveta brata Ciril i Metod & 1864 & 66 & 3 & 0 & 51 & 10 & 2 \\
\hline M. Pleteršnik & Slovo o polku Igorjeve & 1866 & $\begin{array}{c}30 \\
(22) \\
\end{array}$ & 3 & 0 & 5 & 5 & 17 \\
\hline F. Levstik & Kdaj začne izhajati nem.-slov. slovar & 1866 & $9(11)$ & 6 & 0 & 2 & 1 & 0 \\
\hline $\begin{array}{l}\text { J. Križaj- } \\
\text { Severjev }\end{array}$ & Tomaž Mor & 1866 & $\begin{array}{c}29 \\
(45)\end{array}$ & 6 & 0 & 9 & 6 & 8 \\
\hline M. Valjavec & Zora in Solnca & 1867 & $\begin{array}{c}29 \\
(36) \\
\end{array}$ & 12 & 0 & 3 & 6 & 8 \\
\hline J. Jurčič & Cvet in sad & 1868 & 52 & 10 & 0 & 6 & 14 & 22 \\
\hline J. V. Koseski & Mazepa Jovan & 1868 & $\begin{array}{c}50 \\
(21)\end{array}$ & 19 & 3 & 3 & 16 & 9 \\
\hline B. Tomšič & Ravni pot najboljši pot & 1868 & $\begin{array}{c}15 \\
(20) \\
\end{array}$ & 1 & 1 & 9 & 4 & 0 \\
\hline M. Vilhar & To sem bil jaz & 1868 & $5(15)$ & 1 & 0 & 1 & 1 & 2 \\
\hline NN & $\begin{array}{l}\text { Poduk kako najboljšo živomejo } \\
\text { zasaditi }\end{array}$ & 1868 & $3(15)$ & 1 & 0 & 0 & 1 & 1 \\
\hline J. Majciger & Slovenski Štajer & 1868 & $9(30)$ & 1 & 0 & 5 & 3 & 0 \\
\hline F. Levstik & Članki v Slovenskem narodu & $\begin{array}{l}1868 \\
1869 \\
\end{array}$ & $\begin{array}{c}32 \\
(51) \\
\end{array}$ & 12 & 2 & 5 & 6 & 7 \\
\hline F. Levstik & Dopisi (Slov. narod) & 1869 & 63 & 26 & 0 & 16 & 12 & 9 \\
\hline S. Šubic & Kaj so hudourni vrtinci & 1869 & $5(15)$ & 2 & 0 & 1 & 0 & 2 \\
\hline F. Jančar & Umni gospodar & 1869 & $\begin{array}{c}10 \\
(10)\end{array}$ & 8 & 0 & 0 & 0 & 2 \\
\hline J. Pajk & Čujte,čujte,kaj slovenski jezik tirja & 1869 & $\begin{array}{c}11 \\
(20)\end{array}$ & 3 & 0 & 6 & 2 & 0 \\
\hline F. Levstik & Doktor Bežanec v Tožbanji vasi & 1870 & $\begin{array}{c}27 \\
(36) \\
\end{array}$ & 7 & 0 & 1 & 1 & 18 \\
\hline J. Jurčič & Lipe; Pipa tobaka & 1870 & $\begin{array}{c}43 \\
(70)\end{array}$ & 11 & 0 & 20 & 5 & 7 \\
\hline J. Stritar & Zorin; Sol & 1870 & 13(70) & 6 & 0 & 4 & 0 & 3 \\
\hline V. Mandelc & Išče se odgojnik & 1870 & $\begin{array}{c}15 \\
(35) \\
\end{array}$ & 0 & 0 & 1 & 5 & 9 \\
\hline J. V. Koseski & Razne dela pesniške in igrokazne & 1870 & 278 & 110 & 17 & 10 & 117 & 24 \\
\hline A. Umek & Slon & 1870 & $4(7)$ & 2 & 0 & 0 & 1 & 1 \\
\hline
\end{tabular}




\begin{tabular}{|l|l|c|c|c|c|c|c|c|}
\hline F. Levstik & Iz minule srečne mladosti & 1871 & $(6)$ & 3 & 0 & 4 & 0 & 0 \\
\hline J. Sernec & Nauk o gospodinjstvu & 1871 & $6(45)$ & 2 & 0 & 2 & 0 & 2 \\
\hline J. Sumper & Slovenski Bučelarček & 1871 & 20 & 10 & 0 & 5 & 0 & 5 \\
\hline NN & Kako ravnati z belim vinom /... & 1871 & $4(15)$ & 3 & 1 & 0 & 0 & 0 \\
\hline J. Ulaga & Kake ustave je Avstriji potreba & 1871 & $\begin{array}{c}18 \\
(50)\end{array}$ & 2 & 0 & 11 & 3 & 2 \\
\hline J. Lapajne & Kranjsko ljudsko šolstvo & 1871 & $\begin{array}{c}12 \\
(71)\end{array}$ & 3 & 0 & 1 & 4 & 4 \\
\hline J. Zima & Telovadba v ljudski šoli & 1872 & $\begin{array}{c}27 \\
(49)\end{array}$ & 4 & 0 & 7 & 6 & 10 \\
\hline $\begin{array}{l}\text { L. Haderlap } \\
\text { I. Hribar }\end{array}$ & Brstje & 1872 & $\begin{array}{c}17 \\
(20)\end{array}$ & 7 & 0 & 5 & 4 & 1 \\
\hline J. Alešovec & Ričet iz Žabjeka & 1873 & $9(20)$ & 2 & 0 & 3 & 3 & 1 \\
\hline F. Levstik & Prevodi in lekoriranje v Vrtcu & $1874-$ & $\begin{array}{c}132 \\
(33)\end{array}$ & 25 & 7 & 60 & 3 & 10 \\
\hline J. Stritar & Gospod Mirodolski & 1876 & $\begin{array}{c}36 \\
(40)\end{array}$ & 15 & 0 & 11 & 9 & 1 \\
\hline F. Levstik & Tugomer & 1876 & 66 & 18 & 2 & 18 & 19 & 9 \\
\hline Gesamt & & $1863-1876$ & 1231 & 368 & 34 & 269 & 318 & 215 \\
\hline
\end{tabular}

\subsection{Tabelle 16}

\begin{tabular}{|c|c|c|c|c|c|c|c|c|}
\hline \multicolumn{9}{|c|}{ V. Periode: Sprachmode } \\
\hline \multirow[t]{2}{*}{ Verfasser } & \multirow[t]{2}{*}{ Titel } & \multirow[t]{2}{*}{ Jahr } & \multirow[t]{2}{*}{$\mathrm{pg} / 100$} & \multicolumn{2}{|c|}{ Partizip } & \multicolumn{3}{|c|}{ Gerundium } \\
\hline & & & & $-\check{c}$ & -ši & $-\mathrm{c}$ & - ši & $-/ a j / e$ \\
\hline D. Trstenjak & Slovanski elementi v venetščini & 1877 & $\begin{array}{c}14 \\
(30)\end{array}$ & 3 & 0 & 3 & 7 & 1 \\
\hline J. Gomilšak & Potovanje v Rim & 1878 & $\begin{array}{c}16 \\
(30)\end{array}$ & 6 & 0 & 1 & 5 & 4 \\
\hline F. Levec & Pravda o slovenskem šestomeru & 1878 & $\begin{array}{c}21 \\
(46)\end{array}$ & 1 & 1 & 12 & 4 & 3 \\
\hline A. Bezenšek & $\begin{array}{l}\text { Svečanost o priliki sedemdesetletnice } \\
\text { dr. Janeza Bleiweisa }\end{array}$ & 1879 & $6(20)$ & 2 & 0 & 4 & 0 & 0 \\
\hline F. Levstik & Nestorjeva kronika & $\begin{array}{l}1879 \\
1880 \\
\end{array}$ & $\begin{array}{r}336 \\
(56)\end{array}$ & 11 & 9 & 107 & 194 & 15 \\
\hline M. Pleteršnik & Prvi dnevi drugega triuverata & 1880 & $\begin{array}{c}19 \\
/ 20)\end{array}$ & 9 & 0 & 3 & 7 & 0 \\
\hline M. Cigale & Znanstvena terminologija & 1880 & $9(30)$ & 3 & 0 & 3 & 2 & 1 \\
\hline L. Lavtar & Nekaj o načrtu za prirodoslovje /... & 1880 & $7(15)$ & 5 & 0 & 1 & 0 & 1 \\
\hline J.F. Haderlap & Tisoč in ena noč & 1880 & $\begin{array}{c}10 \\
(63)\end{array}$ & 1 & 0 & 6 & 2 & 1 \\
\hline J. Kersnik & Rokovnjači; Luterski ljudje & $\begin{array}{l}1881 \\
1882\end{array}$ & 106 & 27 & 3 & 30 & 38 & 8 \\
\hline
\end{tabular}




\begin{tabular}{|c|c|c|c|c|c|c|c|c|}
\hline J. Jurčič & Rokovnjači & 1881 & $\begin{array}{c}34 \\
(20)\end{array}$ & 19 & 1 & 2 & 10 & 2 \\
\hline J. Mencinger & Mešana gospoda & 1881 & $\begin{array}{c}15 \\
(37) \\
\end{array}$ & 2 & 0 & 4 & 7 & 2 \\
\hline I. Tomšič & Carjevič Rudolf $/ . .$. & 1881 & $\begin{array}{c}10 \\
(10)\end{array}$ & 3 & 0 & 5 & 2 & 0 \\
\hline F. Erjavec & Somatologija & 1881 & $\begin{array}{c}19 \\
(50)\end{array}$ & 7 & 0 & 9 & 3 & 0 \\
\hline NN & Bratovščina /... & 1881 & $3(10)$ & 2 & 0 & 1 & 0 & 0 \\
\hline F. Haderlap & $\begin{array}{l}\text { Zbirka ljubimskih in ženitovanjskih } \\
\text { pisem }\end{array}$ & 1882 & $6(20)$ & 3 & 0 & 2 & 1 & 0 \\
\hline J. Mencinger & Cmokavzer in Ušperna & 1883 & $\begin{array}{c}12 \\
(28) \\
\end{array}$ & 4 & 0 & 4 & 2 & 2 \\
\hline J. Trdina & Bajke in povesti o Gorjancih; Dolenci & $1881 / 2$ & 188 & 42 & 12 & 35 & 91 & 8 \\
\hline I. Macun & $\begin{array}{l}\text { Književna zgodovina Slovenskega } \\
\text { Štajerja }\end{array}$ & 1883 & 54 & 6 & 2 & 20 & 26 & 0 \\
\hline F. Marešič & Lurški majnik ali molitvenik & 1883 & 19 & 9 & 0 & 7 & 3 & 0 \\
\hline I. Tavčar & Slovenski Pravnik & 1883 & $\begin{array}{c}49 \\
(50) \\
\end{array}$ & 12 & 0 & 19 & 18 & 0 \\
\hline A. Trstenjak & Fr. Ks. & 1883 & $\begin{array}{c}14 \\
(20)\end{array}$ & 1 & 0 & 5 & 6 & 2 \\
\hline J. Babnik & Sledovi slovenskega prava & 1883 & $4(15)$ & 2 & 0 & 1 & 1 & 0 \\
\hline H. Majer & Odkritje Amerike & $1883 / 4$ & 104 & 12 & 0 & 39 & 31 & 22 \\
\hline J. Pajk & Črtice iz duševnega žitka /... & 1884 & $\begin{array}{c}18 \\
(30)\end{array}$ & 4 & 0 & 11 & 3 & 0 \\
\hline N. Mozetič & Pot v nebese & 1884 & 25 & 6 & 0 & 8 & 4 & 7 \\
\hline I. Vrhovnik & Tisočletnica Metodova & 1885 & $7(15)$ & 0 & 0 & 4 & 3 & 0 \\
\hline I. Skuhala & Duhovnija s. Križa nad Mariborom & 1886 & $5(15)$ & $\underline{0}$ & 1 & 1 & 3 & 0 \\
\hline F. Rakuša & Domoznanstvo ormoškega okraja & 1886 & $\begin{array}{c}12 \\
(30) \\
\end{array}$ & 3 & 1 & 5 & 2 & 1 \\
\hline B. Trnovec & Sodn & 1886 & $\begin{array}{c}41 \\
(50) \\
\end{array}$ & 8 & 3 & 5 & 19 & 6 \\
\hline F. Levstik & edniški popravki v Vrtcu & $\begin{array}{l}1887 \\
1896 \\
\end{array}$ & $\begin{array}{c}127 \\
(16)\end{array}$ & 25 & 0 & 57 & 38 & 7 \\
\hline F. Jamšek & Šolske drobtinice & 1887 & $6(21)$ & 2 & 1 & 2 & 1 & 0 \\
\hline V. Oblak & Trije slovenski rokopisi /...J & 1887 & $\begin{array}{c}24 \\
(20)\end{array}$ & 3 & 0 & 20 & 1 & 0 \\
\hline I. Križanič & Žlahtna rozga Slovenskih Goric & 1888 & $\begin{array}{c}14 \\
(50) \\
\end{array}$ & 5 & 0 & 4 & 3 & 2 \\
\hline I. Železnikar & Životopis Dr. Valentina Zarnika & 1888 & $4(15)$ & 0 & 0 & 1 & 3 & $\underline{0}$ \\
\hline V. Ribnikar & Logaško okrajno glavarstvo & 1889 & $9(15)$ & 1 & 0 & $\underline{2}$ & 5 & 1 \\
\hline A. Levec & $\begin{array}{l}\text { Zbirka obrazcev za slovensko } \\
\text { uradovanje pri sodiščih }\end{array}$ & 1889 & \begin{tabular}{|c|}
73 \\
$(80)$ \\
\end{tabular} & 18 & 3 & 29 & 17 & 6 \\
\hline
\end{tabular}




\begin{tabular}{|c|c|c|c|c|c|c|c|c|}
\hline $\mathrm{NN}$ & $\begin{array}{l}\text { Pouk, kako si moremo pridobiti } \\
\text { slovenskih šol na Koroškem }\end{array}$ & 1889 & $2(15) \mid$ & 2 & 0 & 0 & 0 & 0 \\
\hline F. Nedeljko & Narodne pripovedke in pravljice & 1889 & $9(10)$ & 2 & 0 & 3 & 4 & 0 \\
\hline A. Funtek & Godec & 1889 & $\begin{array}{c}18 \\
(20)\end{array}$ & 9 & 0 & 7 & 0 & 2 \\
\hline I. Križanič & Bela žena & 1890 & $6(32)$ & 3 & 0 & 3 & 0 & 0 \\
\hline J. Jesenko & Zemljepis za prvi razred srednjih šol & 1890 & $3(20)$ & 2 & 0 & 0 & 0 & 1 \\
\hline F. Jamšek & $\begin{array}{l}\text { Napake pri vzgoji v zverižnosteznem } \\
\text { vrtu }\end{array}$ & 1890 & 34 & 14 & 0 & 8 & 3 & 9 \\
\hline I. Tavčar & 4000 & 1891 & $\begin{array}{c}32 \\
(84)\end{array}$ & 8 & 2 & 14 & 4 & 4 \\
\hline I. Vrhovnik & Janez Cigler slovenski pisatelj & 1892 & $\begin{array}{c}10 \\
(20)\end{array}$ & 0 & 1 & 5 & 3 & 1 \\
\hline M. Cilenšek & Naše škodljive rastline & 1892 & $16(30)$ & 9 & 0 & 4 & 3 & $\underline{0}$ \\
\hline A. Aškerc & Izlet v Carigrad & 1893 & $\begin{array}{c}21 \\
(36) \\
\end{array}$ & 10 & 2 & 3 & 2 & 4 \\
\hline Petrovič & Ratmir & 1893 & $\begin{array}{c}15 \\
(20)\end{array}$ & 3 & 0 & 4 & 7 & 1 \\
\hline Miklavec & Protivnja & 1893 & $\begin{array}{r}28 \\
(20) \\
\end{array}$ & 8 & 1 & 8 & 8 & 3 \\
\hline J. Simonič & Kako postanemo stari & 1893 & 21 & 19 & 0 & 2 & 0 & 0 \\
\hline J. Babnik & $\begin{array}{l}\text { Nemško-slovenska pravna } \\
\text { terminologija }\end{array}$ & 1894 & $\begin{array}{c}17 \\
(20)\end{array}$ & 5 & 0 & 9 & 2 & 1 \\
\hline A. Kosi & Najnavadnejše jezikovne napake/... & 1894 & $9(12)$ & 3 & 0 & 4 & 0 & 2 \\
\hline F. Gabršek & Nazorni pouk v ljudski šoli & 1894 & 68 & 10 & 0 & 31 & 9 & 18 \\
\hline N. Meznarič & $\begin{array}{l}\text { Zgodovina čudodelne podobe Matere } \\
\text { Božje } / . . .\end{array}$ & 1894 & $4(20)$ & 2 & 0 & 1 & 0 & 1 \\
\hline S. Gregorčič & Izgubljeni sin & 1894 & $5(10)$ & 0 & 0 & 0 & 1 & 0 \\
\hline A. Benkovič & Gardist & 1895 & $\begin{array}{c}11 \\
(20)\end{array}$ & 4 & 0 & 3 & 3 & 1 \\
\hline Petrovič & V gradu in pod gradom & 1895 & $\begin{array}{r}45 \\
(30) \\
\end{array}$ & 5 & 0 & 17 & 23 & 0 \\
\hline A. Marušič & Epizoda iz kulturne zgodovine /... / & 1895 & $4(15)$ & 0 & 0 & 1 & 2 & 1 \\
\hline J. E. Krek & Čme bukve kmečkega stanu & 1895 & 25 & 13 & 1 & 8 & 2 & 1 \\
\hline F. Govekar & V krvi; Dr. Stmad & $1895 / 6$ & $\begin{array}{c}40 \\
(70)\end{array}$ & 11 & 1 & 13 & 13 & 2 \\
\hline B. Matek & Aritmetika /.../ & 1896 & $7(16)$ & 1 & 0 & 1 & 4 & 1 \\
\hline M. Hostnik & Jeli vse "prastarina"? & 1896 & $7(16)$ & 1 & 0 & 1 & 4 & 1 \\
\hline J. Lesar & Doneski za zgodovino Alojzijevišča & 1896 & $7(20)$ & 2 & 1 & 4 & 0 & 0 \\
\hline
\end{tabular}




\begin{tabular}{|l|l|c|c|c|c|c|c|c|}
\hline $\begin{array}{l}\text { Zeitungen, } \\
\begin{array}{l}\text { Zeitschriften } \\
\text { Sammel- } \\
\text { bände }\end{array}\end{array}$ & $\begin{array}{l}\text { Slovenski prijatelj, Cvetje, Duh. } \\
\text { pastir, Slovenec, Vesna, Rogač, } \\
\text { Saljivi Jaka, Gospodarski glasnik, } \\
\begin{array}{l}\text { Popotnik, Slovan, Angeljček, } \\
\text { Zgodnja danica, Zvon, Lj. zvon, } \\
\text { Dom in svet }\end{array}\end{array}$ & 1877 & 426 & 143 & 14 & 134 & 112 & 23 \\
\hline Gesamt & \multicolumn{2}{|c|}{$1835)$} & & & & & & \\
\hline
\end{tabular}

\subsection{Tabelle 17}

\begin{tabular}{|c|c|c|c|c|c|c|c|c|}
\hline \multirow{2}{*}{ Verfasser } & \multirow{2}{*}{ Titel } & \multirow{2}{*}{ Jahr } & \multirow{2}{*}{$\mathrm{pg} / 100$} & \multicolumn{2}{|c|}{ Partizip } & \multicolumn{3}{|c|}{ Gerundium } \\
\hline & & & & $-\breve{c}$ & -ši & $-\check{c}$ & $-\breve{s i}$ & $-/ a j / e$ \\
\hline F. Malavašič & Nemški Pavliha v slovenski preobleki & 1879 & $\begin{array}{c}23 \\
(40) \\
\end{array}$ & 3 & 0 & 4 & 16 & 0 \\
\hline F. Orožen & Metodika zemljepisnega pouka & 1898 & $5(20)$ & 3 & 0 & 1 & 1 & 0 \\
\hline A. Medved & V Marijinem Celju & 1898 & $8(20)$ & 4 & 0 & 4 & 0 & 0 \\
\hline F. K. Meško & Bajke o kreposti; Moj prijatelj & 1898 & $\begin{array}{c}27 \\
(35) \\
\end{array}$ & 15 & 0 & 10 & 0 & 2 \\
\hline J. Leban & Na Različnih potih & 1898 & $\begin{array}{c}29 \\
(40) \\
\end{array}$ & 8 & 0 & 6 & 12 & 3 \\
\hline F. Grivec & Božična noč & 1899 & $\begin{array}{c}11 \\
(20)\end{array}$ & 5 & 0 & 1 & 4 & 1 \\
\hline F. Levec & Slovenski pravopis & 1899 & $\begin{array}{c}32 \\
(20) \\
\end{array}$ & 9 & 0 & 10 & 7 & 6 \\
\hline F. Ilešič & $\begin{array}{l}\text { Seveda "bralec" in še marsikaj; } \\
\text { Matematiški problemi v slovnici }\end{array}$ & 1899 & $\begin{array}{c}10 \\
(10)\end{array}$ & 2 & 2 & 5 & 1 & 0 \\
\hline M. Napotnik & Blagoslovljenje Cesar /... & 1899 & $6(34)$ & 2 & 0 & 4 & 0 & 0 \\
\hline F. S. Finžgar & Šmarnice nikar; Kvišku & $1898 / 9$ & $7(10)$ & 3 & 0 & 4 & 0 & 0 \\
\hline Z. Kvedrova & Sam; Težko & $1898 / 9$ & $2(10)$ & 2 & 0 & 0 & 0 & 0 \\
\hline I. Cankar & Jakob Ruda; Pesmi & $\begin{array}{l}1898- \\
1900\end{array}$ & $8(50)$ & 5 & 0 & 2 & 0 & 1 \\
\hline R. Perušek & $\begin{array}{l}\text { O rabi dovršnih in nedovršnih } \\
\text { glagolov v novi slovenščini }\end{array}$ & 1903 & $8(10)$ & 6 & 0 & 1 & 1 & 0 \\
\hline K. Štrekelj & $\begin{array}{l}\text { Nekaj prispevkov k slovenski } \\
\text { bibliografiji }\end{array}$ & 1906 & $6(10)$ & 1 & 0 & 2 & 2 & 1 \\
\hline Zeitschriften & Ljubljanski zvon, Dom in svet & $\begin{array}{r}1898- \\
1900 \\
\end{array}$ & $\begin{array}{c}23 \\
(20)\end{array}$ & 9 & 0 & 8 & 2 & 4 \\
\hline Gesamt & $1897-$ & -1906 & 205 & 77 & 2 & 62 & 46 & 18 \\
\hline
\end{tabular}




\section{RAZVOJ DELEŽNIŠKO-DELEŽIJSKIH SKLADOV NA -Č IN -ŠI V SLOVENSKEM KNJIŽLEM JEZIKU 19. STOLETJA}

V zgodovinskem razvoju slovenskega knjižnega jezika je razvoj deležniško-deležijskih skladov na -č. in -ši slabo raziskan, čeprav gre za značilno slovensko skladenjsko sredstvo, na katerega so opozarjali vsi slovničarji od A. Bohoriča naprej. V slovenščini so oblike na - $\breve{c}$ in -ši predvsem knjižne, najpogosteje zelo redke, pa vendar prisotne, čeprav so se v osrednjeslovenskem prostoru vse do 19. stoletja oblike na -ši skoraj izgubile; iz narečij so povsem izginile, v knjižni rabi pa so bile bolj izjema kot pravilo. Povsem drugačno pa je bilo stanje $v$ vzhodnoslovenskem (tj. panonskem) jezikovnem prostoru, saj je prekmurski knjižni jezik 18. in prve polovice 19. stoletja ohranil bogato deležniško-deležijsko izražanje, ki je bilo v skladnji zelo podobno skladenjskemu sistemu teh oblik v stari cerkveni slovanščini. Ker sta se osrednje- in vzhodnoslovenska knjižna različica vse do 19. stoletja razvijali ločeno, takšna raba pri prekmurskih protestantskih in katoliških piscih ni mogla vplivati na jezikovne razmere v osrednji Sloveniji tako dolgo, dokler Slovenci, živeči v avstrijskem delu monarhije, na prelomu 18. in 19. stoletja niso dobili informacij, da se tudi onstran Mure, na Ogrskem, nekaj dogaja s slovenskim jezikom.

Oživljanje starih oblik na -č in -ši v osrednjeslovenskem knjižnem jeziku prve polovice 19. stoletja in njihov vdor v oblikoslovno-skladenjski sistem enotnega slovenskega knjižnega jezika druge polovice 19. stoletja sta posledica soočanja razlikovalnih skladenjskih sestavov dveh tipov slovenskega knjižnega jezika in normiranja skupnega slovenskega knjižnega jezika sredi 19. stoletja, in sicer ob razvojno-zgodovinskem upoštevanju rezultatov glasoslovno-oblikoslovno-skladenjskih zakonitosti slovenskega knjižnega jezika, upoštevajoč pri tem arhaičen starocerkvenoslovanski deležniško-deležijski sestav in posnemovalno skladenjsko. podobo vzhodnoslovenskega knjižnega jezika na prelomu 18. in 19. stoletja. Pri M. Ravnikarju je sicer še šlo za "sorazmerno nesrečen poskus aplikacije", vendar pa je F. Metelko v slovnici (1825) popravil vse oblikoslovne in funkcijske nespretnosti svojega sodobnika, tako da so se še pred sredino stoletja oblike razširile na celotno slovensko jezikovno ozemlje. Njihova pogostost se je $\mathrm{v}$ 19. stoletju spreminjala in je bila $\mathrm{v}$ primerjavi $\mathrm{z}$ rabo $\mathrm{v}$ središčnem tipu knjižnega jezika od P. Trubarja do J. Japlja ter razsvetljenskih in romantičnih leposlovnih prizadevanj ves čas zelo visoka, vendar pa $\mathrm{z}$ izjemo F. Levstika nikoli takšna kot v prekmurskem knjižnem jeziku 18. in prve polovice 19. stoletja.

1. Pogostost oblik na -č in -ši je bila odvisna od:

1. VRSTE SLOVSTVA (cerkveno in posvetno slovstvo).

V osrednjeslovenskem jezikovnem prostoru so se oblike na -č in -ši dobro "prijele" v posvetnem slovstvu, cerkveni pisci pa jih praviloma niso sprejeli, saj so se držali dvestoletne knjižne tradicije in so upoštevali le preobrazbo na koncu 18. stoletja, ki je izhajala iz živega govora središča Slovenije.

2. FUNKCIJSKOZVRSTNE DELITVE BESEDIL (umetnostna in neumetnostna, tj. praktičnosporazumevalna, strokovna in publicistična besedila).

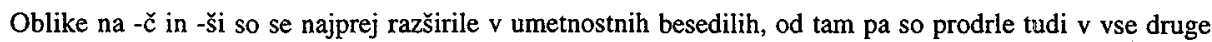
funkcijske zvrsti slovenskega jezika. Najpogosteje so jih uporabljali J. Trdina, I. Tavčar, J. Jurčič in F. Levstik slednji je v zadnjem ustvarjalnem obdobju izdelal samosvoj knjižni jezik, ki je izhajal iz stare cerkvene slovanščine in je upošteval tudi bogato funkcijsko razvejanost oblik na -č in -ši.

3. ČASA (šest obdobij v razvoju oblik na -č in -ši v jeziku 19. stoletja).

I. obdobje (do 1815): Jezikovna zaprtost.

II. obdobje (1815-1824): Nekritično prevzemanje in oživljanje.

III. obdobje (1825-1862): Popravljanje in jezikovna odprtost.

IV. obdobje (1863-1876): Normiranje.

V. obdobje (1877-1897): Jezikovna moda.

VI. obdobje (po 1897): Opuščanje in izginjanje.

II. Vzroki za nepričakovano oživljanje oblik na -č in -ši v slovenskem knjižnem jeziku 19. stoletja:

A - "odkritje arhaičnega vzhodnoslovenskega (prekmurskega) knjižnega jezika, ki je ohranil deležniškodeležijsko izražanje; 
B - iskanje slovenske narodne identitete in tistih jezikovnih možnosti, ki so Slovence približevale skupnemu slovanskemu prostoru;

C - odsotnost učinkovitih skladenjskih sredstev za strnjanje v osrednjeslovenskem knjižnem jeziku;

D - normiranje vseslovenskega knjižnega jezika, ko sta se po predhodnem približevanju in prevzemanju predvsem oblikoslovno-skladenjsko-leksikalnih prvin poenotili osrednje- in vzhodnoslovenska knjižna različica;

E - modnost oblik na -č in -ši v 19. stoletju.

III. Razlogi za opuščanje deležniško-deležijskih skladov na -č in -šì v slovenskem knjižnem jeziku konec 18. st.:

A - nastop nove generacije pišočih (slovenska moderna);

B - odsotnost oblik na -č in -ši v živem govoru;

C - poenotenje slovenske knjižne norme in prehod prekmurske knjižne ustvarjalnosti v narečne okvire.

Pri izrinjanju deležniško-deležijskih skladov na -č in -ši iz slovenskega knjižnega jezika konec 19. stoletja je šlo za obraten potek kot pri oživljanju: oblike so bile najprej oblikoslovno in skladenjsko umetno oživljene $v$ slovnicah slovenskega (osrednje-, vzhodno- in "novoslovenskega") knjižnega jezika, od tam pa so se razširile v knjižno rabo (v živi govor niso bile sprejete); izrinjanje pa se je začelo najprej $v$ literaturi in šele kasneje so te procese v jeziku normirali jezikoslovci in slovničarji. Oživljanje je bilo dolgotrajno in neuspešno, izrinjanje pa hitro in temeljito. 